Portland State University

PDXScholar

12-23-1997

\title{
Abstract Art and Controversy: A Case Study of Louis Bunce's Airport Mural and Other Portland Art Controversies
}

Michael P. Craven

Portland State University

Follow this and additional works at: https://pdxscholar.library.pdx.edu/open_access_etds

Part of the Art and Design Commons, and the Sociology Commons Let us know how access to this document benefits you.

Recommended Citation

Craven, Michael P., "Abstract Art and Controversy: A Case Study of Louis Bunce's Airport Mural and Other Portland Art Controversies" (1997). Dissertations and Theses. Paper 4296.

https://doi.org/10.15760/etd.6180

This Thesis is brought to you for free and open access. It has been accepted for inclusion in Dissertations and Theses by an authorized administrator of PDXScholar. Please contact us if we can make this document more accessible: pdxscholar@pdx.edu. 


\section{THESIS APPROVAL}

The abstract and thesis of Michael P. Craven for the Master of Arts in Sociology were presented October 20, 1997 and accepted by the thesis committee and the department.

COMMITTEE APPROVALS:

Robert William Shotola, Chair

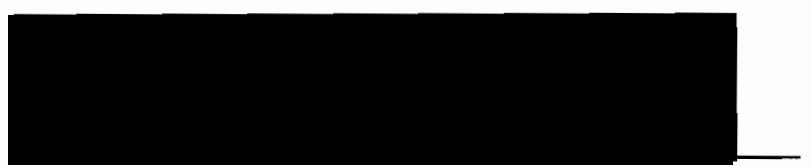

Robert C. Liebman

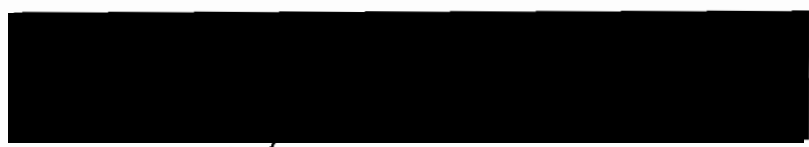

Harry Widman

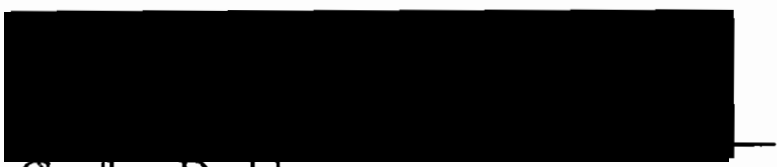

Gerdon Dodds

Representative of the

Office of Graduate Studies $\cap$

DEPARTMENT APPROVAL:

Robert William Shotola,

Chair Department of Sociology

$* * * * * * * * * * * * * * * * * * * * * * * * * * * * * * * * * * * * * * * * * * * * * * * * * * * * * * * * * * * * * * * * * * * * *$

ACCEPTED FOR THE PORTLAND STATE UNIVERSITY BY THE LIBRARY 


\section{ABSTRACT}

An abstract of the thesis of Michael P. Craven for the Master of Arts in Sociology presented October 20, 1997.

Title: Abstract Art and Controversy: A case study of Louis Bunce's airport mural and other Portland art controversies.

This thesis examines a series of controversies in Portland, Oregon during the 1950s triggered by the placement of modern art in strategic public locations. This study examines the controversy surrounding the installation of Louis Bunce's mural at the Portland International Airport and the series of modern art controversies that followed the mural incident.

From archival research and participant interviews, a historical overview was created. When Louis Bunce's mural for the Portland Airport was proposed, it created a controversy that mobilized both opponents and proponents of modern art. In the years following the airport controversy the subsequent controversies motivated opponents of modern art to formally organize.

This thesis evaluates the theoretical discussions by Becker, Dubin, Biesel, and Bourdieu that pertain to art controversies. Existing explanations rely on four factors present in the Portland case:

A) The centrality and symbolic importance of the placement of the controversial work(s). 
B) A community that does not share a common agreement over the conventions that define art work, or in Bourdieuian terms, a difference in cultural capital between the actors involved.

C) A resentment arising from the class demarcation inherent in the cultural capital value of the art, expressed as criticism of the elite class or their cultural proxies, the consecrated artists.

D) An ability of the critics of art to convert their cultural capital deficit into political capital by utilizing homologies of interest with broader ideological issues.

This thesis suggests that three other factors are to be considered when examining art controversies:

E) An opportunity for public exposure of the processes of cultural production arising out of a failure of elite coordination of consecration.

F) A series of controversies, or a prolonged extension of one controversy, that allow participants time to establish positions and strategies.

G) The positioning of both the cultural producer and the cultural critic to maintain the "anti-economy" of their positions.

Of these three additional factors the most important to the ultimate outcome of a controversy is the last; the ability to maintain the antieconomy positions. 


\section{ABSTRACT ART AND CONTROVERSY: A CASE STUDY OF LOUIS BUNCE'S AIRPORT MURAL AND OTHER PORTLAND ART CONTROVERSIES}

by

MICHAEL P. CRAVEN

A thesis submitted in partial fulfillment of the requirements for the degree of

MASTER OF ARTS

in

SOCIOLOGY

Portland State University

1997 


\section{Acknowlegements}

I wish to thank the faculty and staff of Portland State University for their support and encouragement. Under Dr. Nona Glazer's tutelage, the early drafts of my thesis proposal were written. Her criticism and encouragement at the early stages were extremely helpful. Because Dr. Robert Liedman urged me to draw the theory, the theoretical discussion was enlivened with schematics and became easier to write. Harry Widman's involvement with the Portland art community provided insights that were critical to the success of this project.

I am deeply grateful to Dr. Robert Shotola who allowed me write about one of his areas of interest. His prior research into this topic provided me with a core of information to begin this study. I am honored that he entrusted me with this material and had confidence that I would create a worthy thesis. As an advisor and mentor he has contributed immensely to my academic success.

My two editors deserve special recognition. First, my partner Jay Harris, who has not only been a proofreader, but also has gently nudged me towards completion. And finally I should thank my former roommate, Sarah Gregory. Firstly, she encouraged me to return to graduate school. Secondly, Sarah has edited this work at every stage and has helped me improve my writing skills. Lastly, her confidence in my skills and fortitude has enabled me to complete this endeavor. 


\section{Table of Contents}

Acknowlegements............................................................................. i

List of Tables ..............................................................................ii

List of Figures ….................................................................................... i v

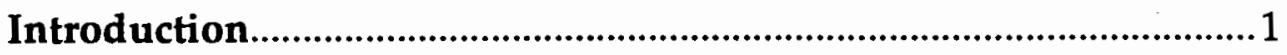

Part One: Historical Overview

Art and Patronage in Portland prior to the Airport Controversy .................................................... 7

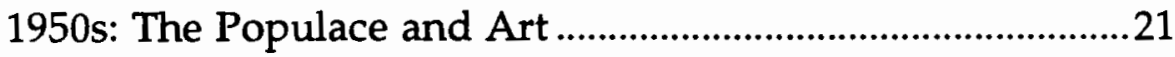

Louis Bunce's Background........................................................31

The Controversial Mural.......................................................49

Continuing Controversy ........................................................67

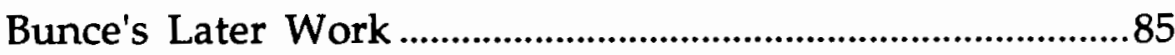

Art and Patronage in Portland since the Controversies .......94

Part Two: Theoretical Discussion

Related Theory ........................................................................96

Putting the Portland Controversies in a Bourdieuian Frame

Bourdieu's Fields.......................................................103

Field of Dominant Power ...............................................106

Field of Cultural Production..........................................111

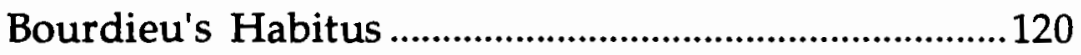

Homologies between Fields ........................................128

Trajectories, Agency,

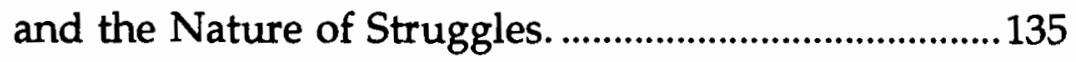

Conclusion

References

Published Material .................................................................. 152

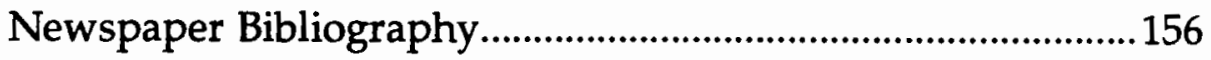

Unpublished Material .............................................................. 162

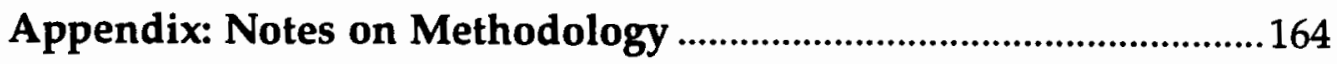




\section{List of Tables}

1: Hofstader's Stages of Anti-Intellectualism ..................................126 


\section{List of Figures}

1: Bimrose, Art, editorial cartoon:And the Fight Goes On, .............4

2 \& 3: Portland International Airport main terminal showing the Oregon Market Place and the Bunce mural...................

4: Photo of Louis Bunce by Robert B. Miller .......................................6

5: Bunce, Louis, Beach, Port Orford ........................................................

6: Bunce, Louis, Mural, Grants Pass Federal Building........................35

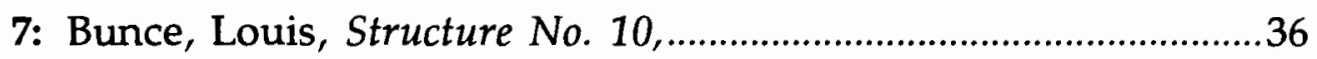

8: Bunce, Louis, Images ........................................................................38

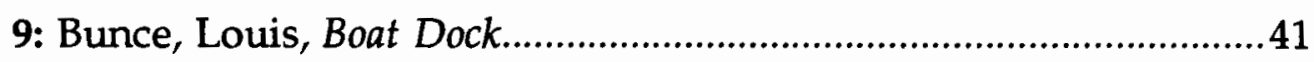

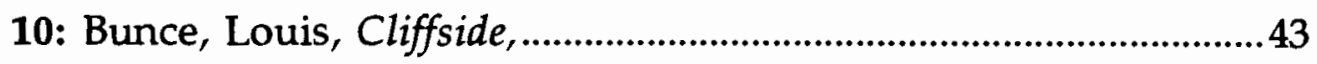

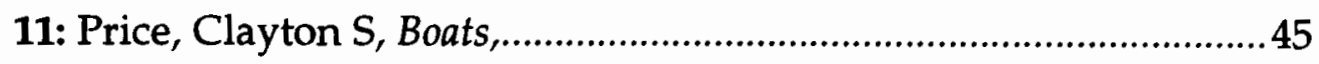

12: Price, Clayton S, Horses in Landscape, ........................................46

13: Life Magazine "Art of the West" showing

Bunce with Beach, Rising Mist...........................................................48

14: Architect's sketch of the Portland Airport Terminal, circa 1940s. 
15: Architect's sketch for the Portland

International Airport, circa 1954

16: Bunce, Louis, Sketch for airport mural.

17: Bunce, Louis, Regions,

18: Photo of Bunce at Work

19: Photo of the airport and the mural

20: Bunce, Louis, Portland Airpot Mural

21: Photo of Bunce signing the "Doughnut Mural"

22: Photo of Bunce's mural for the Centennial Expo 70

23: Photo of the murals by various Northwest artists. 71

24: Photo of the Mrs C. G. Murphey .73

25: Photo of an Art for Oregonians protester 74

26: Page from the Scrapbook of Mrs. C. G. Murphy .75

27: Page from the Scrapbook of Mrs. C. G. Murphy. .76

28: Page from the Scrapbook of Mrs. C. G. Murphy. 77

29: Page from the Scrapbook of Mrs. C. G. Murphy. .78

30: Photo of the Mrs C. G. Murphy denouncing the State Fair Art Jury. 


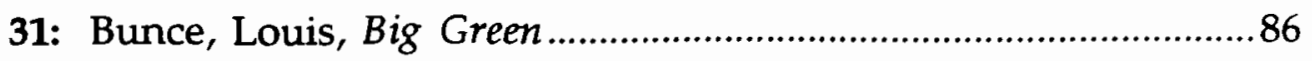

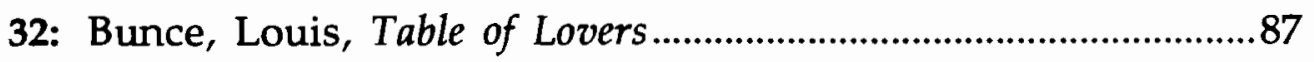

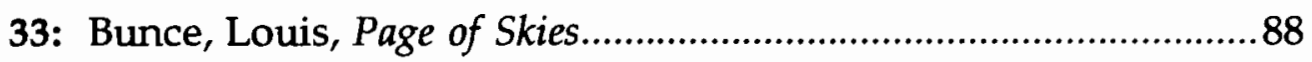

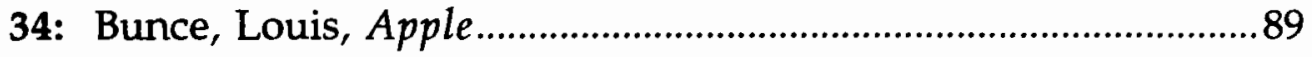

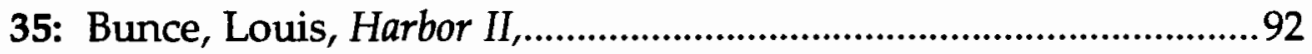

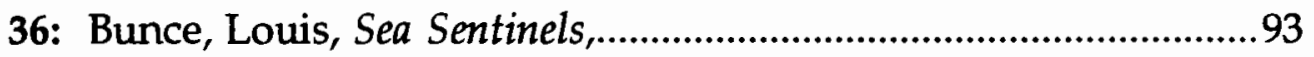

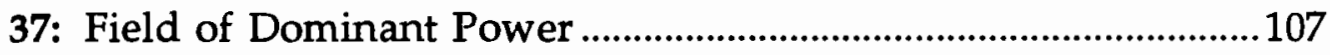

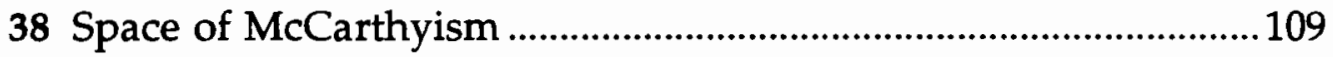

39: Field of Dominant Power, Portland, 1958 .................................110

40: Greater Field of Power Relations ............................................... 112

41: Consecration in the Field of Cultural Production.....................117

42: Field of Cultural Production, Portland 1958...............................119

43: Space of Cultural Struggle, Realist vs. Abstract .........................120

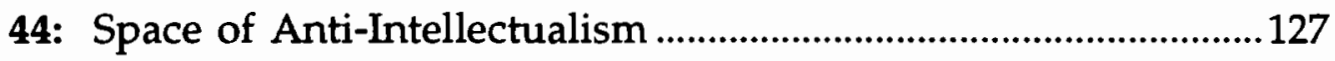

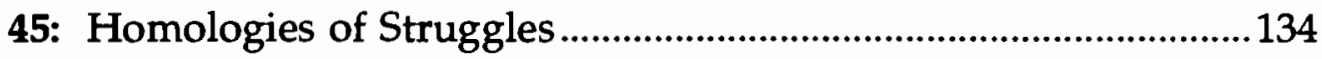

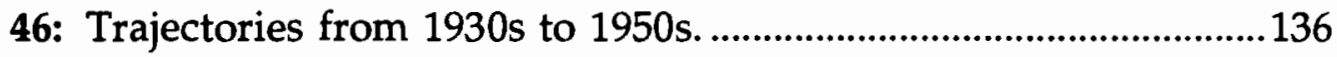

47: Schematic of the CCAO Controversies.......................................141 


\section{Introduction}

When the Portland International Airport was remodeled in the early 1980s, it was heralded as the first major airport to feature local merchants that sell regional goods. The Oregon Market Place in the center of the main terminal building features a Powell's Bookstore, a Nike athleticwear shop, a Norm Thompson clothing store, and a Real Mother Goose's Arts and Craft shop selling myrtlewood bowls and Chihulyinspired art glass. Tucked above a Coffee People espresso stand and competing with banners advertising pizza and jelly beans, is a large abstract mural that goes unnoticed by most hurried travelers passing by (Figures 2 and 3). It takes effort to pick out the painting among the visual noise of the mini-mall. Nothing about this painting would suggest that it was once the most talked-about piece of art in Portland and a work that inspired cartoons (Figure 1) and poems. In 1959 a Portland newspaper printed the following poem:

If I were Bunce (not Common Clay)

And I could paint in a clever way

Birds and Flowers, grass and trees

Ample nudes with dimpled knees

And my studio began to fill

With unsold works from door to sill

I'd look in my mirror and say,"You dunce

Don't be a run-of-the-mill named Bunce

Start painting pictures so bizarre

They'll talk of you from near and far." 
(And it would work, as everyone knows

Who's read Aesop's bit on the Emperor's Clothes.)

Then I'd set to work and blob and smear

and name my efforts "Hope" or "Fear"

And I'd laugh till tears ran down my face

As I gathered plaudits from the human race.

I'm not saying that this happened once

But it would have happened if I were Bunce.

- June Russel. 1

The debate surrounding this mural rallied the fans and foes of modern art to the civic battlefield. The artist who painted the mural found himself the subject of nearly a hundred hostile letters to the local papers and had garbage dumped on his front yard. Louis Bunce (Figure 4), an artist acclaimed in New York, found himself pilloried in his hometown.

This study examines the controversy surrounding the installation of Louis Bunce's mural at the Portland International Airport. It also explores the series of modern art controversies in Portland that followed the mural incident. These cases deserve analysis because they are not easily explained by the existing theories pertaining to art controversies. Sociologists and art historians have analyzed art controversies in which the ideological content of the work in question is easily identifiable. The Portland controversies were about abstract art, supposedly an art free of content. Yet the combatants in these controversies readily attributed ideological content to 
these works. The controversy over abstract expressionist art in Portland of the 1950s raises many interesting questions about what meaning different groups of viewers attribute to art and how society decides who has the right to define art. These cases provide a unique opportunity to examine the cultural divides that exist between the sponsors of avant-garde art and that art's vocal detractors. 
4

Figure 1: Bimrose, Art, Editorial Cartoon: And the Fight Goes On, Oregon Journal clipping of Mrs C. G. Murphy, (circa 1960).

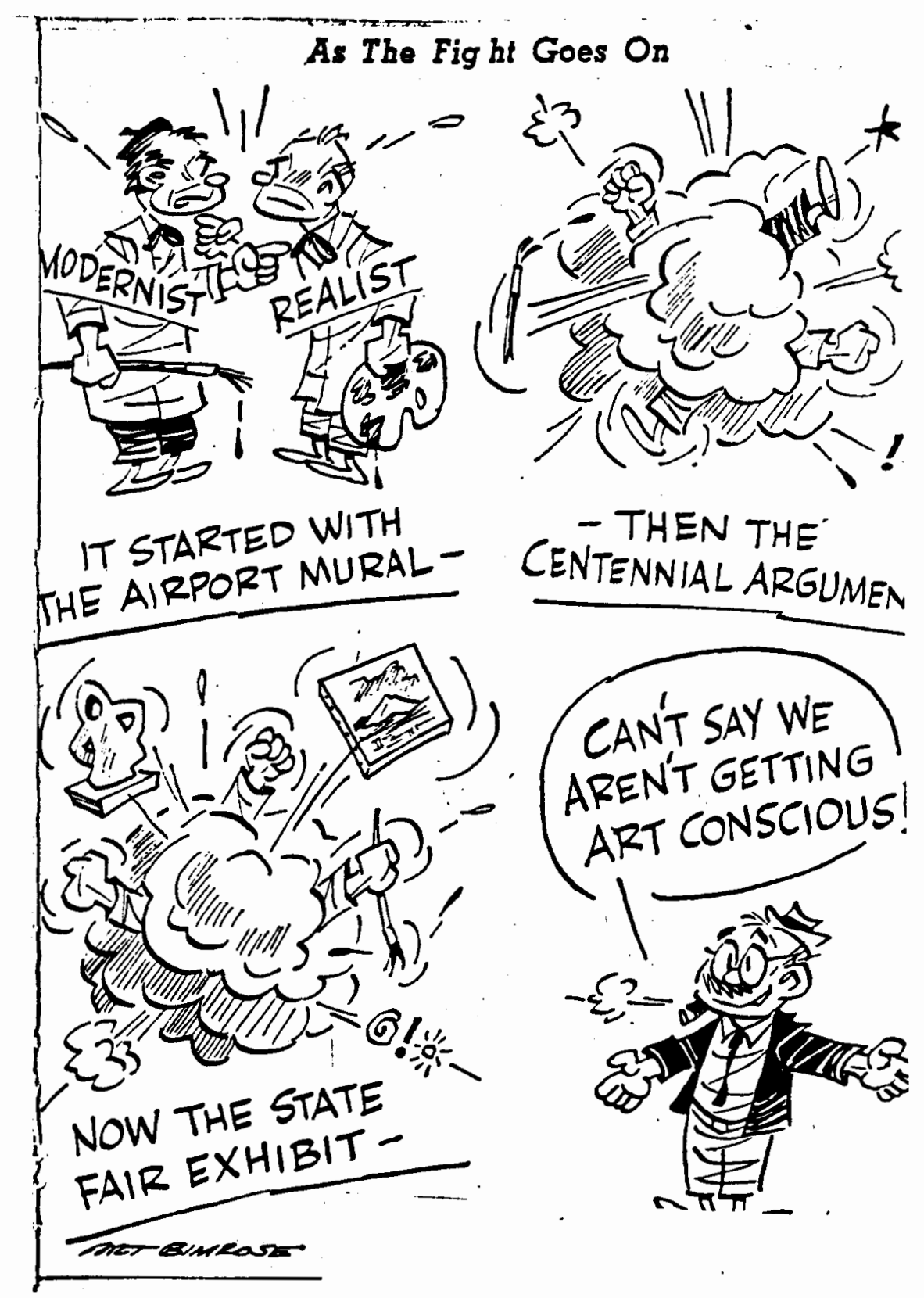


Figures 2 \& 3: Portland International Airport main terminal showing the Oregon Market Place and the Bunce mural.

Authors' photos, 1996.
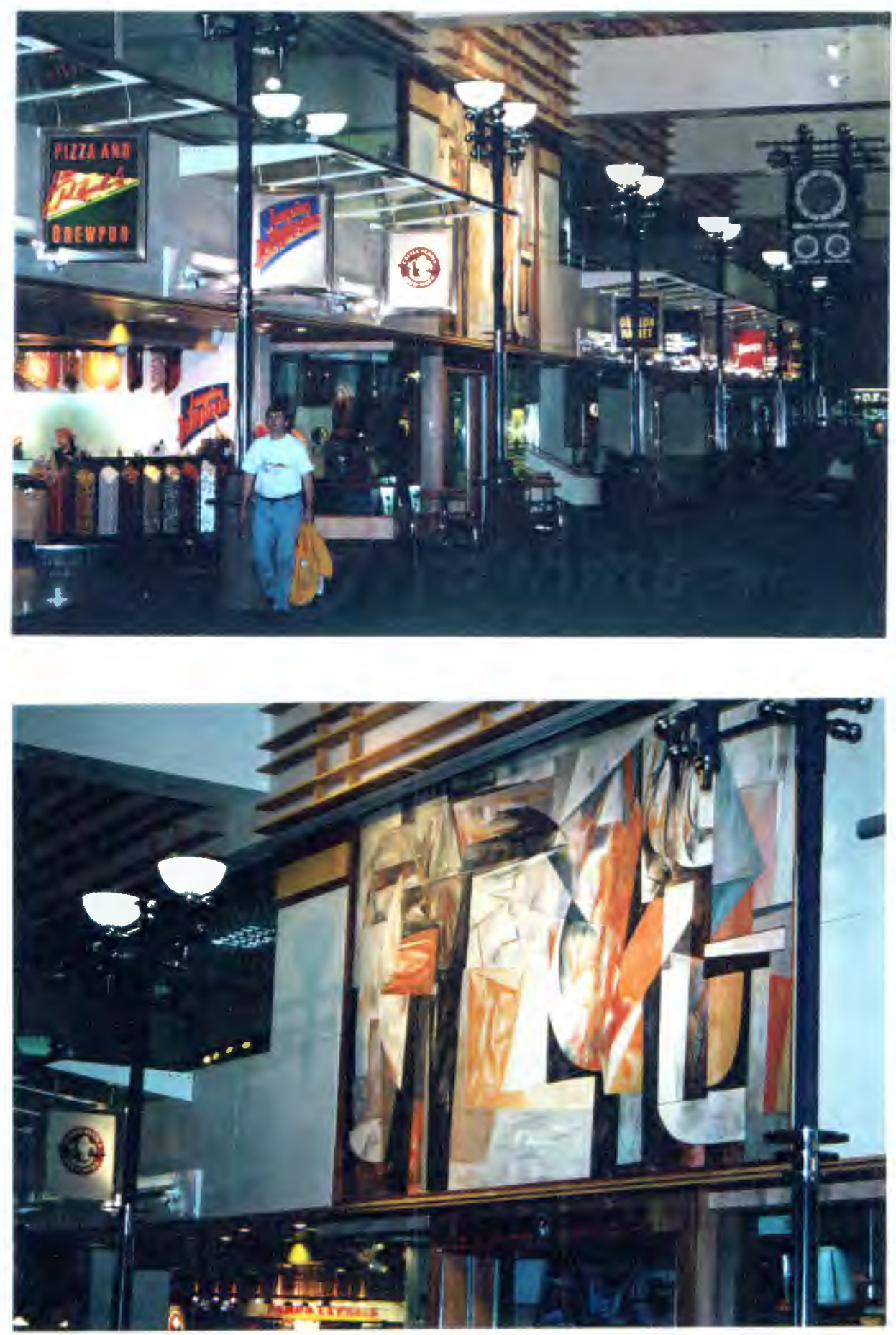
Figure 4: Photo of Louis Bunce by Robert B. Miller - circa 1979.

Rosenfield, Rachel. Louis Bunce, A Retrospective, exh. cat., (Portland Art Museum, 1979), title page.

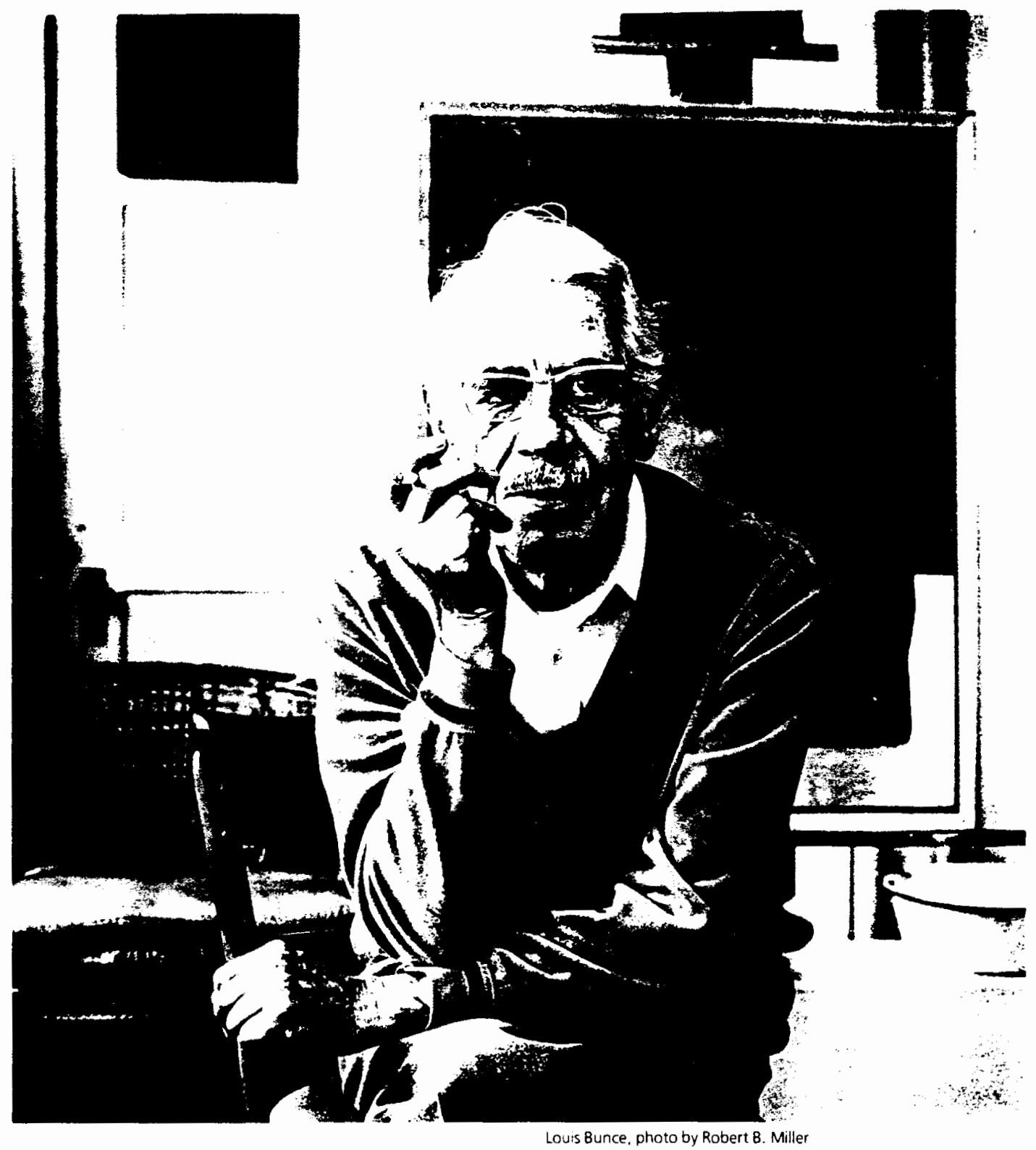




\section{Part One: Historical Overview}

\section{Art and Patronage in Portland prior to the Airport Controversy}

Portland was settled in the mid 19th century and by the late 1890s had developed into the cultural center of the Northwest, surpassed on the West Coast only by San Francisco. At the turn of the century, the city boasted a symphony and an art museum. In 1911 Reed College was founded and soon burgeoned into a nationally respected institution. These and other cultural organizations were founded and run by the same elite families that dominated Portland's economy and politics. Lumber, real estate, and commerce had produced a Brahmin class in Portland who modeled their civic philanthropy after Eastern cities such a Boston. As Robert Shotola noted in "Artistic Activity in Portland, 1890 - 1950,"

Portland -- particularly earlier Portland -- is frequently described as a city in the New England mold. That definition implies such characteristics as stability, civility, gentility, traditionalism, a sense of noblesse oblige, and the tendency to associate worldly success with moral virtue. Portland also has been a community in which the "public good" was largely defined and assured through private judgment and mechanisms: the judgment of those who mattered, and the mechanisms of those who could afford them. ${ }^{2}$

The largest visual arts organization and center of visual art activity in the city was the Portland Art Association's Museum and Art School.

${ }^{2}$ Shotola, Robert, unpublished paper: "Artistic Activity in Portland, 1890 - 1950", (1981), p. 
The Portland Art Association was founded in 1892 and by 1905 had its own small museum. ${ }^{3}$ The Museum's initial collection began with 200 plaster casts of Greek and Roman sculptures. ${ }^{4}$ Most of the Museum's early exhibitions were of academic and traditional work; however, the Museum showed many modern artists following their New York debuts. In 1914, the Museum, under the leadership of curator Anna Belle Crocker, brought to Portland an exhibition that featured the modern art of Marcel Duchamp and other controversial modernists who had been introduced to America the prior year at the famous Armory Exhibition. Included in the show was Duchamp's Nude Descending a Staircase. In 1923 and 1924, the Museum displayed exhibitions of contemporary French and American art, including Brancusi's Muse. These shows were assembled in New York by the Portland collector and Museum volunteer Sally Lewis, who was responsible for another notable modern exhibition: the 1927 exhibit of paintings, drawings, and lithographs by Kandinsky, Klee, and others of the Blue Rider group.

In 1909, with the financial support of socialite and arts patron Julia Hoffman, the Museum founded its art school. By the 1920s the school presented a regular schedule of classes and offered a two year, non-degree,

3 Oregon Journal, "Modern art stirred city 50 years ago", (Sept. 6, 1952), s. 2, p. 1.

4Portland Art Association, unpublished report: "Some Landmarks", (1960), p. 1. 
day course. ${ }^{5}$ While records show that few students completed a course of study at the Museum, many Portland artists began their formal training at the Art School. ${ }^{6}$ Louis Bunce, Jack McLarty, and Bill Givler are prominent examples.

From its founding to the 1950s, the Museum and its school were the center of "serious" art production in Portland. No other institution provided regular exhibition space for modern art, and more important, the Museum also provided a livelihood for the "serious" artist who taught there. During the first part of the century, Portland had a limited art market. The only artists who were able to support themselves from sales were those who painted portraits and landscapes. The avant garde artist could either live like C. S. Price in "monk-like poverty"7 or he could teach art classes at the Museum.

While earlier modern artists did not expect to earn living wages practicing their craft, by the 1950s, a large number of artists did. The New Deal art programs of the 1930s such as the Work Progress Administration, Treasury Relief Art Project, and Public Works of Art Project treated artists as valued professionals. Most of the New Deal projects in the Portland area such as Timberline Lodge were "Arts and Crafts" oriented, because, "in the

${ }^{5}$ Griffin, Rachael, "Portland and its Environs", Art of the Pacific Northwest: From the 1930s to the Present, ed. Adelyn Breeskin, (Washington, DC: Smithsonian Institution Press, 1974), p. 5.

6 Shotola, p. 3.

${ }^{7}$ Shotola, p. 5. 
words of one WPA official 'We didn't have enough real artists here.' "8 However, a small number of easel paintings were done in Portland. Bunce, Price, and others did some easel works for the WPA that were later given to the Museum. Many artists who later became prominent in the Portland Art scene also participated in WPA easel and mural projects elsewhere in the country. Michele Russo and Louis Bunce both participated in projects on the East Coast. Russo noted that, "It was an extraordinary experience for the majority of artists to earn a living and to work full-time and devote all their attention to art." 9

World War II had a profound impact on artists and their expectations. Traveling as soldiers exposed many potential artists to the cultures of Europe and Asia. In addition to seeing the important art of these cultures, this experience also showed artists cultures where artists were valued as professionals. After the war the G.I. Bill greatly expanded the opportunity for artists to study art. Schools like the Portland Museum Art School all experienced dramatic growth in the number of students enrolled. The larger numbers of students also meant that more artists like Louis Bunce and Jack McLarty could find employment as art instructors. ${ }^{10}$

Artists, like other tradespeople, saw the thirties and forties as an opportunity to improve their working conditions. Forming artist-centered

${ }^{8}$ Shotola, p. 8.

${ }^{9}$ Shotola, p. 9.

${ }^{10}$ McLarty, Jack \& Barbara, unpublished interview with Michael P. Craven, (1996), unpaginated. 
organizations was one path to that end. Portland artists organized a small chapter of the American Artists' Congress. In addition to artistic issues, the Congress was also concerned with broader social issues. Its motto was "For peace, democracy, and social progress."11 One Portland exhibit by the group called for works "in defense of democracy in Spain."12 One source told Robert Shotola that the local group fell apart when "a new art director came to town and convinced some of the members to drop out of the organization, presumably because of its political involvement."13

In a effort to secure a regular gallery space, local artists organized the Oregon Artist Guild in 1948. Jack McLarty estimated that by the late forties there was a group of about fifteen serious artists working in Portland, most of whom had studied in New York. ${ }^{14}$ It was the East Coast trained artists who formed the core of the Guild. Eventually about 25 members joined the Guild and the membership included most of the "serious" artists working in Portland. While many of the members of the Guild shared a progressive social vision, unlike the Artists' Congress, the Guild was not overtly political. Jack McLarty recalls the beginning of the Guild:

That was Bill Givler's idea really and he originated this because he liked the idea of a guild at a professional level. We only started with about fifteen that were on that level. And that's when I first met some of these people like the

${ }^{11}$ Shotola, p. 11.

${ }^{12}$ Ibid.

${ }^{13}$ Ibid.

${ }^{14}$ McLarty. 
Runquist brothers and Price. Bill Givler sent me around to see if I could get these guys to become members in the guild. They wanted as strong of a group as possible to go to the Museum and ask for a gallery - which they reluctantly got out of them. 15

The Guild was put in charge of a small gallery in the Museum and presented group shows and one-man exhibitions. Unfortunately, a new director came to the Museum in the mid-fifties and took away the group's control over the space, apparently to use the area to stage larger and more popular exhibitions. ${ }^{16}$ The new director created a special Artist's Membership of the Museum whose purpose consisted of picking juries for the Oregon Annual Exhibition and selecting local artists for the occasional one person show.

If the WPA gave the new generation of Portland artists the hope that they could practice art as a profession, that hope was heightened by the reception given the Abstract Expressionists of the New York School after World War II. Jackson Pollock and others were celebrated in Life magazine, courted by important collectors including Peggy Guggenheim, and were earning substantial sums.

Louis Bunce and other Portland artists knew Pollock and other sucessful New York painters from their days together at the Art Student's League and the New York WPA Easel Project. Bunce and Pollock remained friends from the early thirties until Pollock's death in 1956. They frequently

15 Ibid.

16 Shotola, p. 12 . 
exchanged letters and spent vacations together. Other Portland artists met or knew personally the celebrated modernists. Jack McLarty later remarked about his pre-war education in New York:

The Europeans suddenly looked human to you. You saw the reproductions and read all of this stuff and then you saw Léger and these other people and you realized they were just people. They were not these remote geniuses. They were human beings just like everyone else. It brought it home ... that you could do it, you could take it in your hands and run with it. ${ }^{17}$

In addition to the successful New York artists, there were regional painters like Mark Tobey of Washington and Clifford Still of California who were receiving national acclaim. Portland artists were aware that a growing number of West Coast artists were receiving recognition and financial success. As Jack McLarty observed about the Portland art market:

In Seattle they did a lot better - although whenever we talked to Seattle artists they said the opposite - because of Tobey and those people. These people had national reputations and the people who bought them were just delighted with themselves. Those who hadn't were just screaming because they had not bought them when they were cheap. So they had bought a awful lot of stuff that had to do with the Northwest School. They bought a lot thinking this would be the next Tobey. The market was twice as good in Seattle as here. 18

${ }^{17}$ McLarty.

18 McLarty. 
While the Museum showed Portland artists and had acquiesced in the late forties to allow local artists to run a small gallery, there were still few commercial outlets for modern art in Portland. Jack and Barbara McLarty recalled that it was difficult to generate sales from the Museum shows because price tags had to be inconspicuous. The only other commercial outlet in Portland for modern art was a furniture store that would hang a small number of paintings in its displays. ${ }^{19}$ In 1949 , Louis Bunce, who was teaching at the Museum Art School, together with his wife Eda, opened the Karuba Gallery. Eda ran the shop during the day while Louis taught at the Art Museum ${ }^{20}$ Nearly all the well-known artists working in the Northwest during the fifties displayed at the Karuba. Jack McLarty, C. S. Price, Bill Givler, the Runquist Brothers, Carl Morris and Mark Tobey are a few examples of the artists featured. ${ }^{21}$ Eda recalled that they never expected to make a great deal of money from the Karuba, and that making sales was particularly difficult during the fifties. ${ }^{22}$ Even when Mark Tobey, the most prominent Northwest artist of that period showed at the Karuba in the early fifties, none of his work sold. ${ }^{23}$ The Karuba was never financially successful and the Bunces relied on Louis's income from

${ }^{19}$ Ibid.

${ }^{20}$ Bunce, Eda, unpublished interview with Michael P. Craven, (1996), unpaginated.

$21_{\text {Ibid. }}$

${ }^{22}$ Ibid.

${ }^{23}$ Rosenfield, Rachel. Louis Bunce, A Retrospective, exh. cat., (Portland: Portland Art Museum, 1979), p. 27. 
teaching at the Art Museum. To increase sales at the Karuba the Bunces featured jewelry and even framing. Finally, in 1955, the Bunces closed the Karuba. Eda Bunce remarked "You can only go in the hole so far." 24 Portland would have no new art gallery to promote commercial sales until October of 1958 when the short lived New Gallery of Contemporary Arts opened. 25

The New Gallery of Contemporary Arts was operated by Norma and Ronald Peterson who had both been students at the Museum School. The gallery was aggressively avant-garde and generally featured more abstract Portland artists like Louis Bunce, Lee Kelley, and George Johansen. ${ }^{26}$ The Portland artist Harry Widman recalled that the gallery was a "New York style gallery" -- stark white walls and few distractions from the exhibited art. ${ }^{27}$ The gallery officially closed in May of $1962^{28}$ although Widman remembered that the last important shows at the gallery were likely in mid-1960.29

While Portland artists were making few sales in their hometown, some were starting to receive modest regional and national recognition.

${ }^{24}$ Bunce, Eda.

${ }^{25}$ Oregonian, "Art Foundation Created", (May,27, 1962), s. 2, p. 10, c. 6.

${ }^{26}$ Widman, Harry, unpublished interview with Michael P. Craven, (1997), unpaginated.

${ }^{27}$ Ibid.

${ }^{28}$ Oregonian, "Art Foundation Created", (May,27, 1962), s. 2, p. 10, c. 6.

${ }^{29}$ Ibid. 
Jack McLarty and others showed occasionally in Seattle galleries. ${ }^{30}$ Of Portland artists, Louis Bunce received the most national attention. Bunce showed at several New York galleries during the early fifties and was featured in a show at the Museum of Modern Art. In 1955, Life magazine featured Bunce in an article on the art of the West. With four other Western modern artists, Bunce was shown in a full color two page spread. ${ }^{31}$ Jon Bunce, Louis's son, speculated that the exposure in Life furthered his father's reputation outside of Portland's art community and helped him secure the airport mural commission. ${ }^{32}$ By the late fifties there was clearly a core group of East Coast trained artists working in Portland who were creating "serious" works. However, despite the national and local recognition these artists achieved, they were still dependent on one institution, the Portland Art Museum, both for an artistic outlet and for their livelihood.

In the 1950s Portland's elite families still dominated the Museum. E. Kimbark MacColl, in The Growth of A City, described how the Museum was run by "a tightly knit board of directors comprising the leaders of Portland's upper crust society and a sprinkling of cultural luminaries."33 MacColl wrote of a 1949 financial scandal that exposed an incident in which

${ }^{30}$ McLarty.

${ }^{31}$ Life, "Art of the West", (November 4, 1957), p. 65 - 69.

32Bunce, Jon, unpublished interview with Michael P. Craven, (1996), unpaginated.

${ }^{33}$ MacColl, E. Kimbark, The Growth of a City, (Portland, Oregon: The Georgian Press, 1979), p. 616. 
the Museum board of directors had not acted in the best interests of the Museum's endowment, but had instead allowed the Museum to be defrauded by more than $\$ 500,000$ during a sale of stock. On the advice of the board's financial committee, the Museum sold its stock in Eastern and Western Lumber prematurely - before the Portland Dock Commission announced that it would buy the company's lumber terminal. MacColl makes a persuasive argument that a significant number of members of the Museum's board of directors knew that the stock was undervalued. ${ }^{34}$ MacColl asserts that the scandal revealed how, similar to city government at that time, the Portland Art Museum was run by "cronies." The institution was governed by men who "knew each other socially and who unquestioningly accepted the financial judgment of their peers."35

L. H. Hoffman (Hawley Hoffman) who was President of the Portland Art Association in 1958, was certainly part of the "upper crust" of Portland society. His father, Lee Hoffman, was the engineer and contractor who had constructed the first Morrison Street bridge. In 1895, when Hawley was eleven, Lee Hoffman was killed in a hunting accident. Shortly after the accident the Hoffman family moved from Portland to the East Coast. While in Boston, Hawley's mother Julia was active in the Boston Arts and Craft Society and took art classes at the Boston Art Student's Association

${ }^{34}$ Ibid., p. 618.

${ }^{35}$ Ibid., p. 616. 
and Hawley attended Harvard. ${ }^{36}$ Julia Hoffman was a gifted photographer whose collection is now at the San Fransico Museum of Modern Art. When the family returned to Portland, Julia helped found the Art Museum School and The Portland Arts and Craft Society. Hawley's sister, Margery Hoffman-Smith, became prominent in the Portland art community, and was the interior designer of Timberline Lodge.

Hawley Hoffman received a degree in architecture from Harvard in 1906, and after a grand tour of Europe, moved back to Portland. He married Caroline Lewis, a member of the Couch-Lewis clan, "Portland's oldest and largest dynasty." $37 \mathrm{He}$ founded his construction company in 1908 and quickly became the leading contractor in Portland. By the late fifties, he was a director of the First National Bank of Oregon, a Port of Portland Commissioner, and the President of the Art Association. He was also a member of the prestigious Arlington Club, a club where Portland's business and banking leadership was centered. ${ }^{38}$ From E. Kimbark MacColl's book The Growth of A City (1977), it is clear that Hoffman was active in local and state politics. He served on several Portland committees, including the anti-communist Civic Protection Committee that was formed to break the 1934 Longshoreman strike. ${ }^{39}$ It was Hoffman's support

${ }^{36}$ Holland, Katherine, Julia Hoffman: A Family Album, exh. cat., (San Fransico: San Fransico Museum of Modern Art Press, 1977), p. 8.

37 Ibid., p. 309.

38 MacColl, p. 3.

${ }^{39}$ Ibid., p. 348. 
of Republican candidates that led to his appointment to the Port of Portland. From the Port's inception, positions on this governor-appointed commission were awarded by patronage. Dennis Lindsay, who was President of the Port Commission in 1958, recalled that Hoffman was a domineering presence on the Port and had strong ideas about how the city should be managed. Lindsay said that when he was first appointed to the Port, Hoffman invited him for drinks at the Arlington Club and "tried to fill my young lawyer head with his ideas about how things should be run." 40

Hoffman was a powerful force on the Port Commission and in Portland politics. In many activites he exercised his considerable influence to derive tangible benefits for his construction firm. It is likely that his motivation to be involved with the Museum was related both to the social prestige of the position and to a sense of noblesse oblige arising from the Hoffman family's history of participating in the arts. As the President of the Art Association, it appears that Hoffman generally followed the advice of the Museum's staff regarding artistic matters. Jack and Barbara McLarty remembered, "When he sat on the board for the School, the School Committee, he was known as being sympathetic to the School ... We heard many negative things about others on that board, but he was not one of them."41 After Hoffman died in 1959, a wing of the Museum was named after him.

${ }^{40}$ Lindsay,Dennis, unpublished interview with Michael P. Craven, (1996), unpaginated.

${ }^{41}$ McLarty. 
The Museum and its sponsorship of modern art was not without critics. By the late 1920s, "traditionalist" painters and their supporters began complaining that the Museum's curators and the school's instructors favored modernism at the expense of realistic and academic styles. In 1927, the Oregon Society of Artists (OSA) formed to represent artists of "recognizable" art. The initial meetings of the group and their first show were held at the Museum ${ }^{42}$ Subsequent shows were held at the Meier and Frank department store and at the public library. Most of the members of the OSA were amateurs, although several commercial artists were also involved. The nationally known artist Ed Quigley, who painted cowboys and clowns, was an active member of the group. During the thirties, several "serious" artists were associated with the group. Charles Heaney and C. S. Price both exhibited their work with the group as late as $1949 .{ }^{43}$ By the late 1940s, the group had severed its relations with the Portland Art Association and the "serious" art community. In 1949, members of the society protested the appropriation of Multnomah County general funds to the Portland Art Museum ${ }^{44}$. Later in 1949, when the Museum instituted a juried selection process for its annual exhibition of Oregon art, the OSA again protested because the jury did not select art submitted by any of the Society artists. Their protest consisted of a show of traditional art in the Park Blocks in front of the Museum. During the early 1950s, the OSA built

${ }^{42}$ van Gent, Ans, unpublished paper: "Oregon Society of Artists", (1980), p. 15.

${ }^{43}$ Shotola, p. 7

44 Oregonian, "Museum Boss Urges Help", (Oct. 13, 1949), p. 12. 
a gallery, classrooms, and studio space on SW Park Street near the Multnomah Athletic Club. Later in the mid 1950s, having their own gallery and classroom space, the OSA stopped actively contesting the Portland Art Association's modern inclinations.

\section{0s: The Populace and Art}

By 1948 the abstract art of the New York School was the emerging dominant paradigm in the contemporary art world that was centered in New York City. Artists, critics, and elite patrons had given up the social realism that had characterized the art of the 1930s, and embraced the styles pioneered by the European Modernists. The American genre was dominated by a handful of critics and patrons who had made overnight sensations of particular New York artists. For example, Peggy Guggenheim placed Pollock, Rothko, Still, Motherwell, and others under contract and sold their works to the New York elite. Clement Greenburg, Robert Rosenberg, and Meyer Schapiro were among the critics who both provided theoretical explanations for these artists and legitimized the ascendancy of their style. Unlike social realism, and to some extent even unlike earlier modern styles, ${ }^{*}$ abstract expressionism furthered modern art's rejection of "literary" concepts of art -- the illusionist and naturalistic portrayal of humans and nature. To understand art one needed to know what the artist was trying to accomplish with form and color. For critics such as

* Pablo Picasso work Guernicia, 1937, is an example of a modern work with ideological content. It was painted in response to the Fascist bombing of Guernicia, Spain. 
Greenburg, art was a product of art theory and no longer referred to anything outside of the art world itself. ${ }^{45}$ Rosenberg felt that subject matter had been abandoned for process: abstract art was a record of the expressions of the artist. ${ }^{46}$

In 1949, Life magazine asked the rhetorical question about Jackson Pollock: "Is he the greatest living painter in the United States?"47 The media coverage that Pollock and the other abstract expressionist painters received from the mainstream press was double-sided. The press celebrated these artists as avant-garde and important, but it also noted that these artists used unorthodox methods. In the Life article, it was noted that Pollock stood on his canvas as he painted. Often the press coverage made jokes at the artist's expense. For example,Time derided Pollock's methods by calling him "Jack the Dripper." 48

If abstract art was the dominant aesthetic paradigm in New York salons, then nostalgic kitsch was the governing paradigm in the living rooms of the average American. In Populux (1986), Thomas Hine explored the American public's fascination with furniture, cars, and even kitchen appliances that reflected the jet age aesthetic. But Hine also notes wryly that

45Greenberg, Clement, "Towards a Newer Laocoon", Art in Theory 1900 - 1990, ed. Harrison, C \& Wood, P, (Cambridge, Mass: Blackwell, 1993), pp. 554-560.

46Rosenberg, Harold, "The American Action Painters", Art in Theory 1900 - 1990, ed. Harrison, C \& Wood, P, (Cambridge, Mass: Blackwell, 1993), pp. 581-584.

${ }^{47}$ Life. "Is he the greatest living paionter in the United States", (Aug. 8, 1949), pp. 42 - 43. ${ }^{48}$ Time, "Chaos Damm It", (Nov. 20, 1950), p. 70. 
Americans did not hesitate to decorate their house with both nostalgic and modern style. "A colonial living room could co-exist with a modern kitchen, and no one would give it a second thought." 49 Americans were selective about the aspects of modernism that they embraced. As for abstract art, the populace was at best ambivalent, and in many instances hostile to the style.

In the popular culture it was not the painters Piccaso or Pollock that were celebrated, but the sentimental illustrator Norman Rockwell and the naive painter Grandma Moses. Moses, who painted nostalgic and simplistic views of country life, declared that, "Anyone can paint if they want to. All they have to do is get a brush and start right in, same as I did." 50

Millions of Americans followed Moses's advice and took up painting as a hobby. Karal Ann Marling amusingly recounts the explosion of amateur painters in the early fifties in As Seen on TV (1994). Marling notes that Americans had unprecedented amounts of free time and new suburban houses to decorate. Hobbies were touted as important for mental heath and were said to be "broadening" for the junior executive. 51 Leather crafts, home woodworking, and model building all became popular as did more artistic hobbies. Painting by number, community art classes, and amateur art societies all boomed during the early fifties. Introduced into

${ }^{49}$ Hine, Thomas, Populuxe, (New York: Knopf, 1986), p. 7.

${ }^{50}$ Marling, Karal Ann, As Seen on T.V., (Cambridge, Mass: Harvard Press, 1994), p. 77.

51 Ibid., p. 58. 
the market place in 1951, paint by number kit sales topped 200 million by 1954.52 Even President Dwight Eisenhower admitted that he enjoyed doing paint by number kits in the evening while he watched television as a form of relaxation. 53

Ike was not the only world leader who dabbled in art. Winston Churchill's artistic abilities were well publicized during the late forties and early fifties. Churchill, however, did not use paint by number sets. He was a talented watercolor artist who published a small book in 1948 called Painting as a Pastime. ${ }^{54}$ According to Marling, "Churchill's insistence was that art was cheap psychotherapy." Marling asserts that the do-it-yourself art movement of the 1950s -- whether for decoration or self psychotherapy -- "subtly devalued legitimate painting."

In 1958, a Portland celebrity published a book of his art work. Stewart Holbrook, a syndicated columnist who lived in Portland, painted under the pseudonym "Mr. Otis." In the introduction to the book, Mr. Otis (1958), Holbrook claimed that Mr. Otis was a "down on his luck" artist that Holbrook had discovered. Holbrook's Mr. Otis paintings lampooned modern art and suggested that the genre was a hoax. The paintings are crudely drawn and often feature elements of collage which are suggestive of the surrealists and Duchamp. Holbrook's titles pay back-handed tribute

${ }^{52}$ Ibid. 66.

53 Ibid.

54 Ibid., p. 67.

$55_{\text {Ibid. }}$ 
to modern art works. Two prime examples include The Dilemma of Piet Mondrian and Nostalgia of a Aged Roué. 56

There were many critics of modern art who dismissed the genre as a hoax, but there were also a substantial number who viewed it as a communist plot. While Senator Joseph McCarthy did not directly attack modern art, many of his comrades saw modern art as un-American. According to Jane Clapp in Art Censorship (1972), Congressman George A. Dondero, Republican from Michigan, "filled many pages of the Congressional Record with attacks on modern art, under the false premise that modern art ... and communism are synonymous." 57 Dondero attacked established museums -- the Museum of Modern Art, the Art Institute of Chicago, the Fogg Art Museum at Harvard University -- and professional art organizations such as Artists' Equity Association for the display of modern art, which he labeled "degenerate." He also believed that guilds of artists should be checked for "heresy," and demanded that art associations, including the National Academy of Design, the American Artists' Professional League, the Allied Artists of America, the Illustrators' Society, and the American Watercolor Society, expel communist members, and "reward the hardworking, talented, reserved, patriotic proponents of academic art." 58 According to Clapp, a number of exhibitors returned paintings to artists named as "subversive," a number of members resigned

56Holbrook, Stuart, Mr. Otis, (New York: McMillin, 1958), p. 4.

57Clapp, Jane, Art Censorship, (Metuchen, N.J.: The Scarecrow Press, 1972), p. 282.

${ }^{58}$ Ibid. 
from the Artists' Equity Association, and artists lost mural commissions and were expelled from conservative clubs." 59

In a March 11, 1949 speech called "Modern Art as Communist Heresy," Congressman Dondero noted that 17 of 28 artists who had loaned paintings to New York City's "Gallery on Wheels" exhibit to government hospital patients were mentioned in the Dies index. ${ }^{* 60}$ In the speech "Communism in the Heart of American Art--What To Do About It," Dondero said, "Modern Art is communistic because it is distorted and ugly, because it does not glorify our beautiful country, our cheerful and smiling people, our great material progress. Art which does not portray our beautiful country in plain, simple terms that everyone can understand breeds dissatisfaction. It is therefore opposed to our government, and those who create and promote it are our enemies"61 In an August 16, 1949 speech, "Modern Art Shackled to Communism," Dondero maintained that

${ }^{59}$ Ibid., p. 283.

*The Dies index was a list compiled by The House Un-American Activities Committee (HUAC) of suspected communist who had worked, or were working for the government. From its creation in 1938, the HUAC had been popularly know as the Dies committee after its founder, Congressman Martin Dies, a Democrat form Texas. A particular target of the committee was New Deal programs and the Roosevelt administration. Presumably it was while participated in WPA and other New Deal art projects that the artist mentioned by Dondero became listed by the HUAC.

60Ibid.

61 Ibid. 
the Armory Show of 1913 was a "red plot." He singled out foreign "isms" as "weapons of destruction to America's priceless cultural heritage." Included in a "role of infamy" of modern art were: "Dadaism, Futurism, Surrealism, Cubism, Expressionism, and Abstractionism."62

Dondero was not alone in his crusade against modern art and its supposed ties to communism. Clapp also documented numerous regional crusades against modernism. In 1951, the City Council of Los Angeles became concerned with "communist infiltration" at the city-sponsored Municipal Art Exhibition in Griffith Park. The council passed a resolution stating that any kind of painting or sculpture other than illustrative realism is "suspect of subversion or sacrilegious."63 The Council's attention had been drawn to a small symbol incorporated in a picture of a sailing boat. The symbol vaguely resembled a hammer and sickle. The painter Rex Brandt explained latter that the symbol held no political significance and only represented the class of sailing vessel. In 1955, a Dallas, Texas patriotic women's group with four hundred members actively opposed modern art. The group, which called itself the Public Affairs Luncheon Club, was upset with the Dallas Museum's sponsorship of artists with "known communist affiliations, to the neglect of many orthodox artists whose patriotism has never been questioned." 64 In a press

62Ibid.

63Ibid., p. 290.

${ }^{64}$ Ibid., p. 307. 
release, the group explained the communist intent of the various "isms" of modernism:

Cubism aims to destroy by designed disorder;

Futurism aims to destroy by the machine myth;

Dadaism aims to destroy by ridicule;

Expressionism aims to destroy by aping the primitive and the insane;

Abstractionism aims to destroy by the creation of brainstorms,

Surrealism aims to destroy by the denial of reason. 65

In 1956, the Dallas County Patriotic Council, a group that included the women's group, protested an exhibition sponsored by Sports Illustrated called "Sports in Art." The Patriotic Council was upset that the show included works by Ben Shahn, Leon Kroll, and William Zorach, artists who the Council insisted had communist links. The artists had been investigated by the Un-American Activities Committee of the United States House of Representatives in the past, but none of them were "listed as communist by the Subversive Activities Control Board."66 After Dallas, the "Sports in Art" show was to go on a worldwide tour sponsored by the U. S. State Department's Information Agency. After the Patriotic Council called the show "subversive" the tour was cancelled. Other regional controversies that linked modern art to communism included the 1953 covering of the Jose Orozco murals at the New School for Social Research

65 Ibid.

${ }^{66}$ Ibid., p. 312. 
in New York ${ }^{67}$ and a 1954 protest over murals at the San Francisco Main Post Office. ${ }^{68}$ It is notable that while many artists were investigated by the House Un-American Activities Committee (HUAC), the most vociferous accusations of communist infiltration of the arts came from local committees like the Dallas Patriotic Council and the rogue congressman, Dondero.

In 1954 the HUAC visited Portland to seek out and expose communists. The focus of the visit was Reed College Professor Stanley Moore. As Michael Munk in "Oregon Tests Academic Freedom in (Cold) Wartime" recounts, Portland painter Michele Russo was also a target of the HUAC. Unlike Reed College which had dismissed its controversial professor, The Portland Museum Art School sheltered and protected Russo. ${ }^{69}$ The dean of students at Reed, Robert Canon, had accused Moore, Russo, and others of being communists.

Apparently based on Canon's statements to FBI agents and on its own investigations, HUAC issued a subpoena ordering Michele Russo ... to appear at its hearings. Tipped off that he was being sought, Russo slipped away to a mountain retreat until the committee left town, and thus was spared interrogation about Canon's accusation that he was a communist. HUAC's political strategy was not

${ }^{67}$ Ibid., p.298.

${ }^{68}$ Ibid., p. 301.

${ }^{69}$ Munk, Michael, "Oregon Tests Academic Freedom in (Cold) Wartime: The Reed College Trustees versus Stanley Moore", Oregon Historical Quarterly, vol. 97, no. 3, (Fall, 1996), p. 292. 
limited to public exposure, their methods also included "informational" visits to employers, intended to assure that their targets would lose their jobs. However, when HUAC staffers visited the art school's dean, William Givler, stating "Do you know that you have a communist on your faculty?" Givler replied, "Everyone knows that," and asked them to leave. Soon thereafter, Givler and Thomas Colt, director of the Art Museum, visited Russo at his home an assured him of their support. "You are not vulnerable," they told him. 70

Russo's disappearance and Givler's and Colt's support of Russo curtailed an extensive investigation of the role of communists in the Portland art community.

It speaks to the general public's indifference to modern art that the art world as a whole mostly escaped the scrutiny of McCarthy's witch hunt. It was more important to rid the motion picture industry of communism than it was to sanitize the art world. Perhaps if McCarthyism had not lost its momentum in the mid-fifties, the anti-communists would have eventually sought to purge the art world of "subversives."

In spite of the hostility of politicians and the apathy of the public, modern artists continued to dominate the serious art world. In the Portland art world, Louis Bunce was one of the few to achieve modest amounts of national recognition. Bunce's professional background is typical of the modernists of his generation. 


\section{Louis Bunce's Background}

Louis Bunce was born in Lander, Wyoming in 1907. He was named after his paternal grandfather, a polygamous Mormon who had three wives, all of whom were sisters. ${ }^{71}$ His parents encouraged the young Bunce's artistic inclinations. After the family moved to Portland in 1920, Bunce took several art classes at Jefferson High School. Bunce recalled that art classes were not particularly interesting. However, an English teacher, recognizing his talents, gave him a project of illustrating the Rime of the Ancient Mariner. Executing this project helped Bunce realize that he wanted to be an artist.72 In 1925, after graduating from high school, Bunce was walking through downtown Portland and saw a flyer for the Portland Art Association's Museum Art School. Bunce first enrolled in night classes filled with "housewives and amateur types."73 After the first term he was able to enroll in the day classes. After a year at the Museum Art School Bunce and his friend Bill Givler decided to go to New York. They had both heard about the Art Students' League of New York and could afford the $\$ 900$ a year tuition. ${ }^{74}$

In 1927 Bunce and Givler enrolled at the Art Students' League where Bunce took classes until the summer of 1931. Three instructors that Bunce

${ }^{71}$ Baker, Doug, Oregon Joumal, "Baker's Dozen: Oregon's Gully Jimson", (Sept. 7, 1977), p. D6.

72 Bunce, Louis, Oregon Historical Society Interview, p. 1.

${ }^{73}$ Ibid., p. 2.

${ }^{74}$ Ibid., p.3. 
had were Boardman Robinson, Max Weber, and William von Schegell. Other instructors who were at the League during this period were Thomas H. Benton and Stuart Davis. Bunce knew many of the artists who would later become prominent in the New York School of art. Bunce met Jackson Pollock during his last year at the League and they remained close friends until Pollock's death. He often went to exhibit openings with Pollock. Bunce attended the first show at the Museum of Modern Art in 1929 and was impressed with the work of Cézanne, Gaugin, Seurat, and Van Gogh. Other exhibits that he saw during this period were those of Picasso, Klee, Miro, Max Weber and Marsden Hartley. Close to this time, he also met Léger.

In 1931 Bunce returned to Oregon. By doing odd jobs and living cheaply, he was able to continue painting. In 1934 Bunce began painting for the Public Works of Art Project. Paid by the canvas, the artists were encouraged to paint "American scene" subjects. Beach, Port Orford (Figure 5) painted in 1934, appears to be a simple beach. However, Bunce clearly employs many modernist touches that he learned during his New York education: the perspective is skewed and there is a de Chirco-like figure casting a shadow on the beach. In 1936 Bunce was hired as an assistant to John Ballator, who was painting a mural for the St. Johns Post Office. After learning the techniques of working with egg tempera and the large scale of

* The Smithsonian has letters from Pollock to Bunce that explain the beginnings of his drip paintings. Given to the Smithsonian by Bunce's son Jon, these letters are often cited by Pollock scholars. 
public murals, Bunce was commissioned to do a mural panel for the Grants Pass Post Office (Figure 6). This realist mural is at first glance very similar to the work of other government muralists. It shows small groupings of Native Americans against the sparse background of Eastern Oregon's terrain. This arrangement and portrayal of village life is reminiscent of Gauguin's Where Do We Come From? What Are We? Where Are We Going? Like Gauguin's Islanders, Bunce's Native Americans appear to be looking up from their everyday chores, contemplating the approach of an unknown future. This work does not have the obvious social realist message that we associate with the 1930s muralists but has a more subtle message that witnesses the fate of Native Americans.

After the Grants Pass mural, Bunce was involved with the Works Progress Administration (W.P.A.) in Salem, Oregon. He was at first a teacher and later the Assistant Director of the Salem W.P.A. office. In 1939 Bunce returned to Portland and became involved with the Easel Project of the Work Projects Administration. The Easel Project only stipulated that an artist produce a certain number of paintings per month - the artist was free to pick the subject matter and style. With this artistic freedom Bunce chose to experiment with Surrealism. Bunce had participated in the 1939 Golden Gate International Exposition. It was at this show that he had seen the work of Giorgio de Chirco, a painter who would strongly influence his next works. In Structure No. 10,1939, (Figure 7) Bunce put a unexplained two-by-four construction in the middle of the familiar Portland sea wall. A 
Figure 5: Bunce, Louis, Beach, Port Orford, 1934.

Rosenfield, Rachel. Louis Bunce, A Retrospective, exh. cat., (Portland Art Museum, 1979), p. 9, fig. 1.

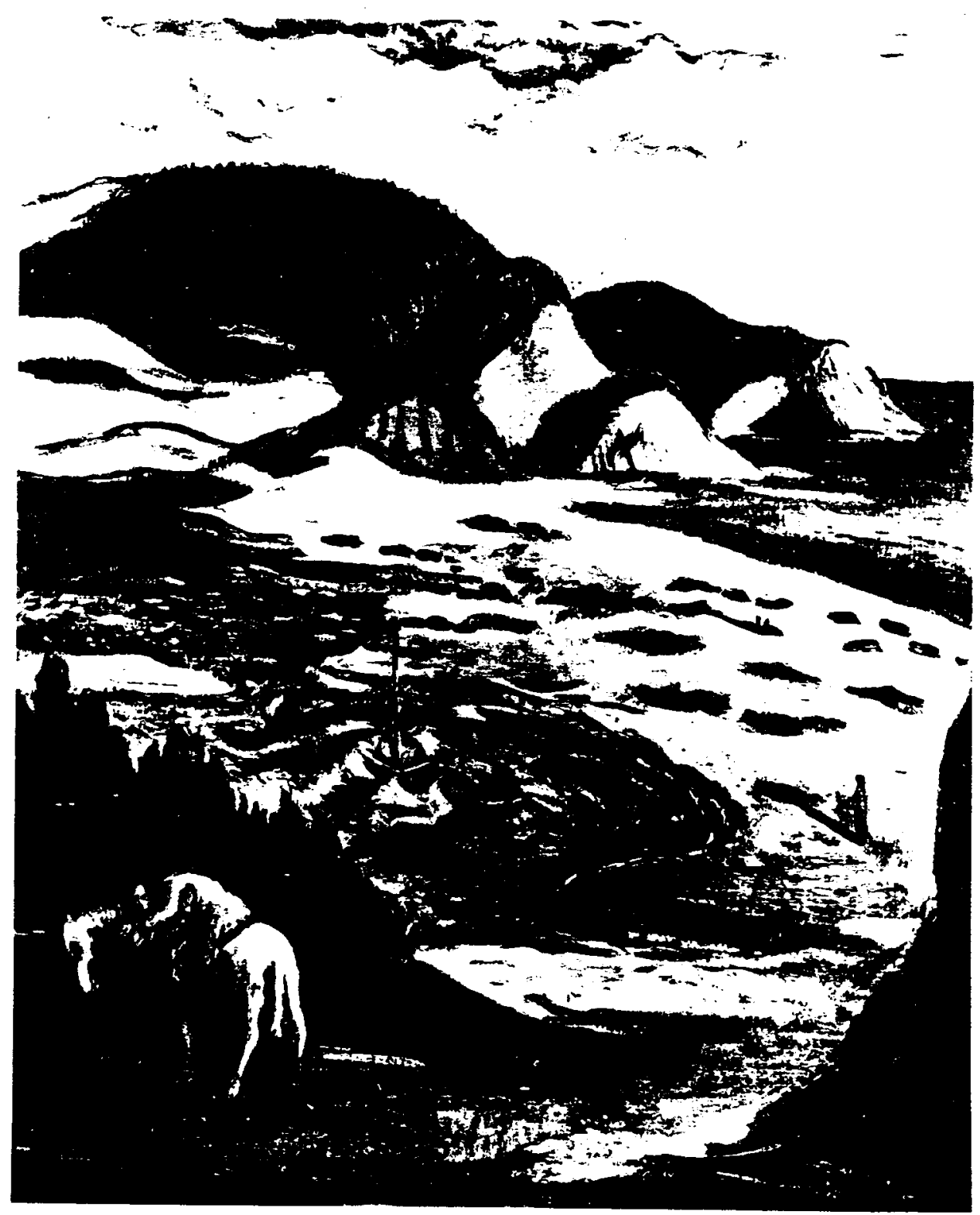


Figure 6: Bunce, Louis, Mural, Grants Pass Federal Building, 1935.

Oregonian, Feb. 16, 1958, p. 28, c. 1, "Space conflict! Port ponders the world of abstract art, Louis Bunce mural for airport".

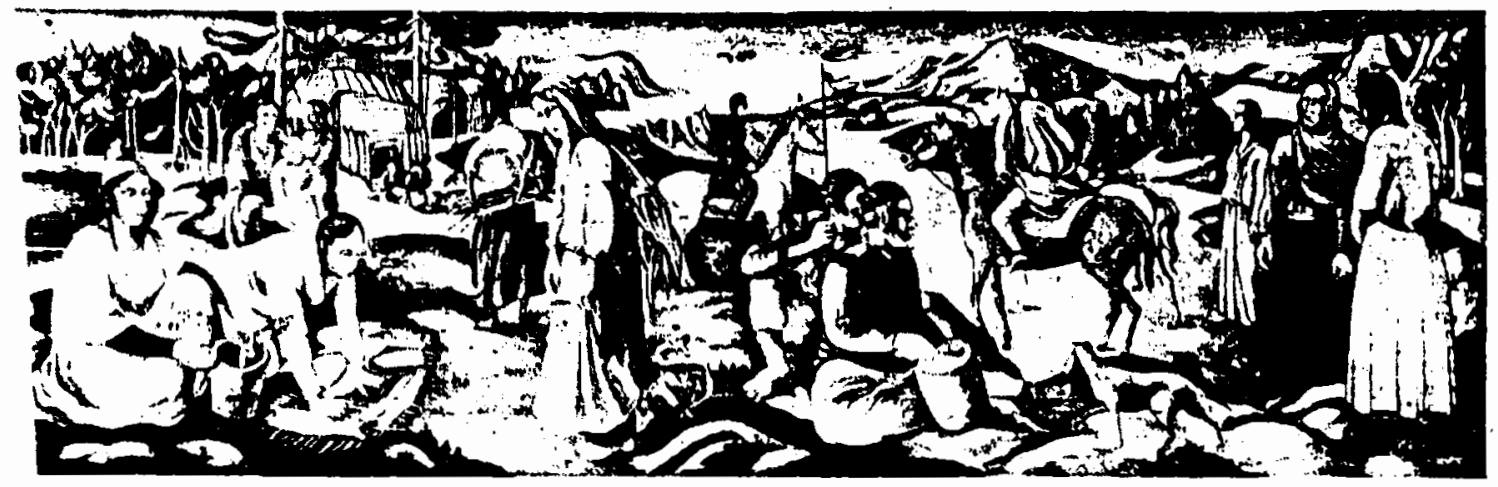


Figure 7: Bunce, Louis, Structure No. 10, 1939.

Kingsbury, Martha. Art of the Thirties, the Pacific Northwest, exh. cat., (Henry Art Gallery, University of Washington Press, 1972), p. 35, fig. 2.

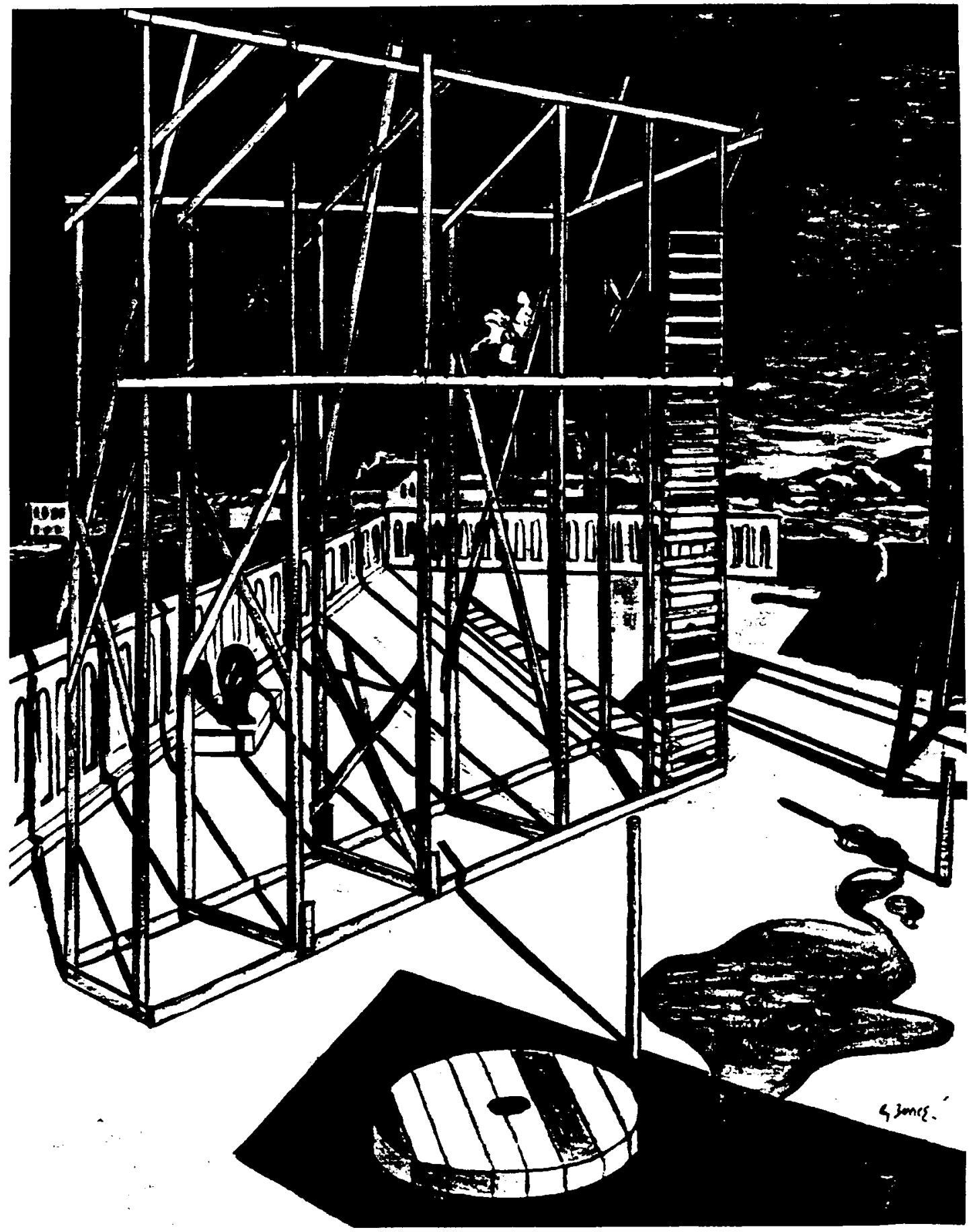


mysterious figure lurks in the shadows and there is an almost Dali-like puddle in the foreground.

In 1939 Bunce returned to New York. On his way to New York, he saw a large exhibition of Picasso's paintings at the Chicago Art Institute. Bunce was familiar with Picasso's work prior to this trip but, as he reminisced in the 1970 s about his early years, he said about the late 1920s:

Picasso worried me for a while. In fact I admired him so much that although it wasn't until later that he was influential on me, I used to buy all of his catalogues and books and gave them away disdainfully. ${ }^{75}$

Bunce's work from 1939 until well after World War II shows both the influence of the Surrealists and Picasso. Images, 1946, (Figure 8) is typical of Bunce's work of this period. There is the Surrealist element of oddly juxtaposed elements: the ship bollard, the giant bird cage and the streetscape. There is also a Léger-like treatment of the city background. While it is hard to see in reproduction, the bird is executed in a manner reminiscent of Picasso.

Very few of Bunce's canvases from his second stint in New York exist. There were so many paintings produced in the New York Easel Project that many of the paintings by Bunce and other artists were eventually sold for scrap. Bunce was told that a junk dealer bought a large number of his paintings with the intention of using the canvas to wrap pipes. ${ }^{76}$

$75_{\text {Rosenfield, p. } 13 .}$

76 Oregonian, "Happy Birthday, Louis Bunce", (Nov. 16,1982), p. E4, c. 1. 
Figure 8: Bunce, Louis, Images, 1946.

Rosenfield, Rachel. Louis Bunce, A Retrospective, exh. cat., (Portland Art Museum, 1979), p. 16 , fig..6.

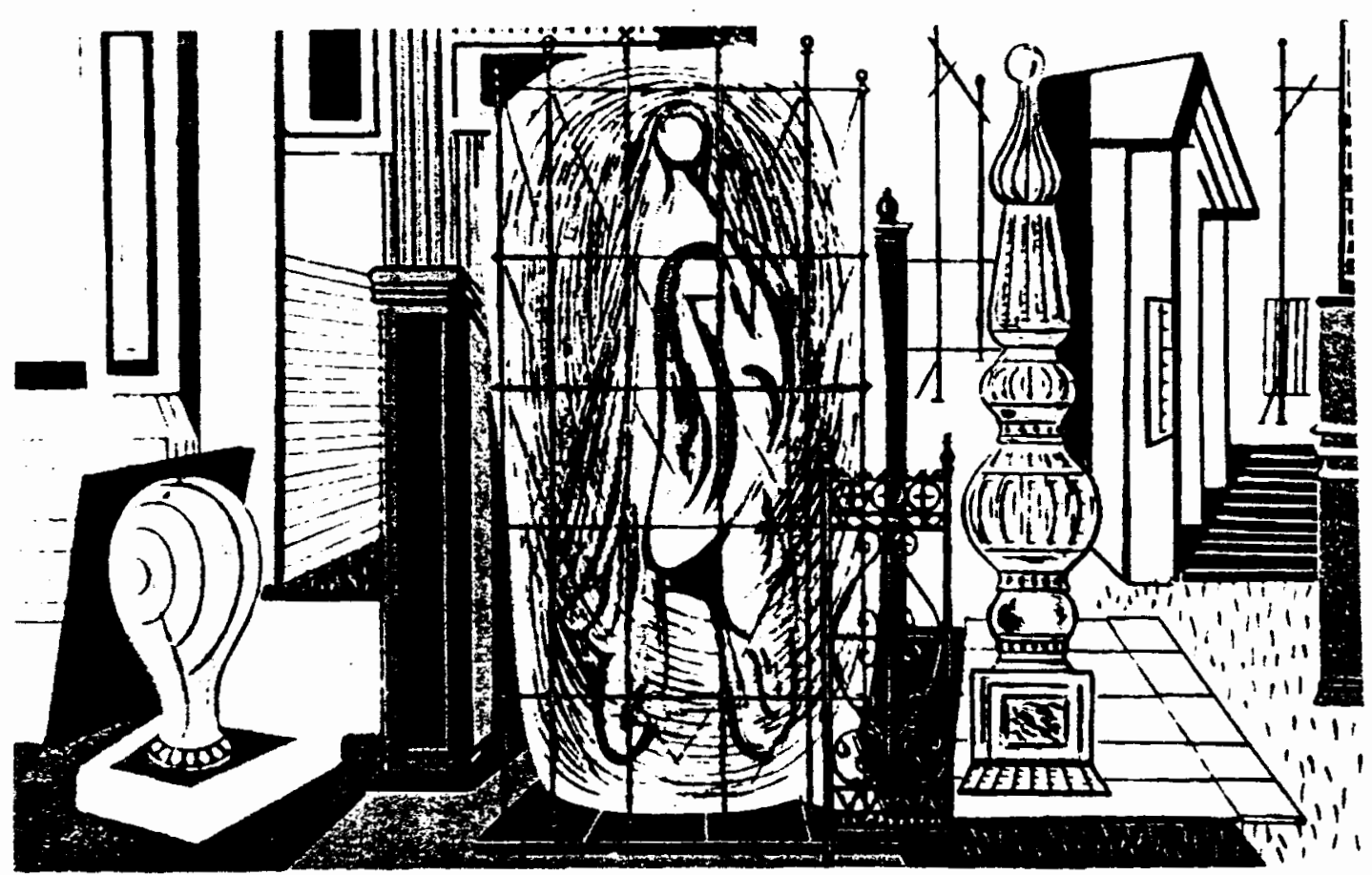


In New York, Bunce participated in the W.P.A. Easel Project until 1942. Jack McLarty later said, "Bunce talked his way on to the W.P.A. project 'illegally' through some friends. He was very charming and good at that."77 Bunce remarked later that during this period he got to "rub shoulders with everyone in the art community."78 In 1940 Bunce became the art editor of Now, a literary magazine that only produced two issues. In his role as editor Bunce became acquainted with Stuart Davis. They became good friends and the two visited many jazz clubs together. During this period Bunce also renewed his friendship with Pollock. Bunce later reflected on the liberty he felt during this stay in New York:

I remember Jack Pollock and I tried to get into a couple of galleries and they just frankly said, 'Well, we like what you're doing, but there's no market for Americans.' They wouldn't take a chance and we got very disgusted. We were all in the same boat. No one actually tried too much to get a gallery because that was remote. You began to think, 'Forget it.' It was very liberating in lots of ways. We worked in our studios and we got together and talked about what we were doing. We really did talk about art constantly it seemed. 79

In 1942 Bunce and Pollock went together to an anti-war protest at the New York Draft Board. With the start of the draft and the ending of federal arts programs, Bunce returned to Portland in late 1942 and was granted a

\section{${ }^{77}$ McLarty.}

${ }^{78}$ Bunce, Louis, Oregon Historical Society Interview, p. 4.

${ }^{79}$ Bunce, Louis, Memorial Service Flyer, (1983), Portland Art Museum Library's Northwest Artist Files: Louis Bunce. 
draft deferment, conditional upon his finding a job in war-related industry. He started working at the Oregon Shipbuilding Company. In the shipyards Bunce's job required him to take the ships' blueprints and create drawings which would help the workers visualize how pieces of the ship were to fit together. Bunce said that the colors of the cold cut steel and the shadows of the shipyard at night are what impressed him most about this experience. ${ }^{80}$

After the war, Bunce was hired as a teacher at the Portland Art Museum School by Bill Givler, who had attended the Art Students' League with him. Until his retirement in 1972, Bunce continued to teach at the Art School. He also spent several summers teaching at the Oregon coastal town of Newport. In Boat Dock, 1952, (Figure 9) Bunce expressed his fascination with the Oregon coast. The work departs from the strong surrealist allusions that characterize Bunce's earlier work. The elements of this work all have a vaguely nautical feeling; the biomorphic shapes suggest clams or fish and the thin lines suggest fish line or rope. The composition of the work is reminiscent of Synthetic Cubism and it has the rhythm and business of a Stuart Davis work. Bunce worked sand into the paint of this canvas - not unlike contemporaries in the New York School.

In the early 1950s Bunce began to paint abstractions of Northwest scenery. Two consistent themes in the fifties were the Oregon coast and the Oregon mountains. Rachel Rosenfield, in her catalog essay, noted that Bunce started painting in larger brush strokes and using larger canvases. ${ }^{81}$

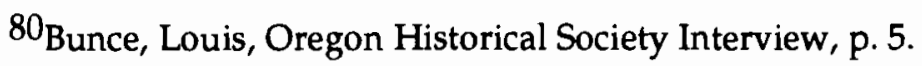

${ }^{81}$ Rosenfield, p. 27. 
Figure 9: Bunce, Louis, Boat Dock, 1952.

Rosenfield, Rachel. Louis Bunce, A Retrospective, exh. cat., (Portland Art Museum, 1979), p. 23 , fig. 9.

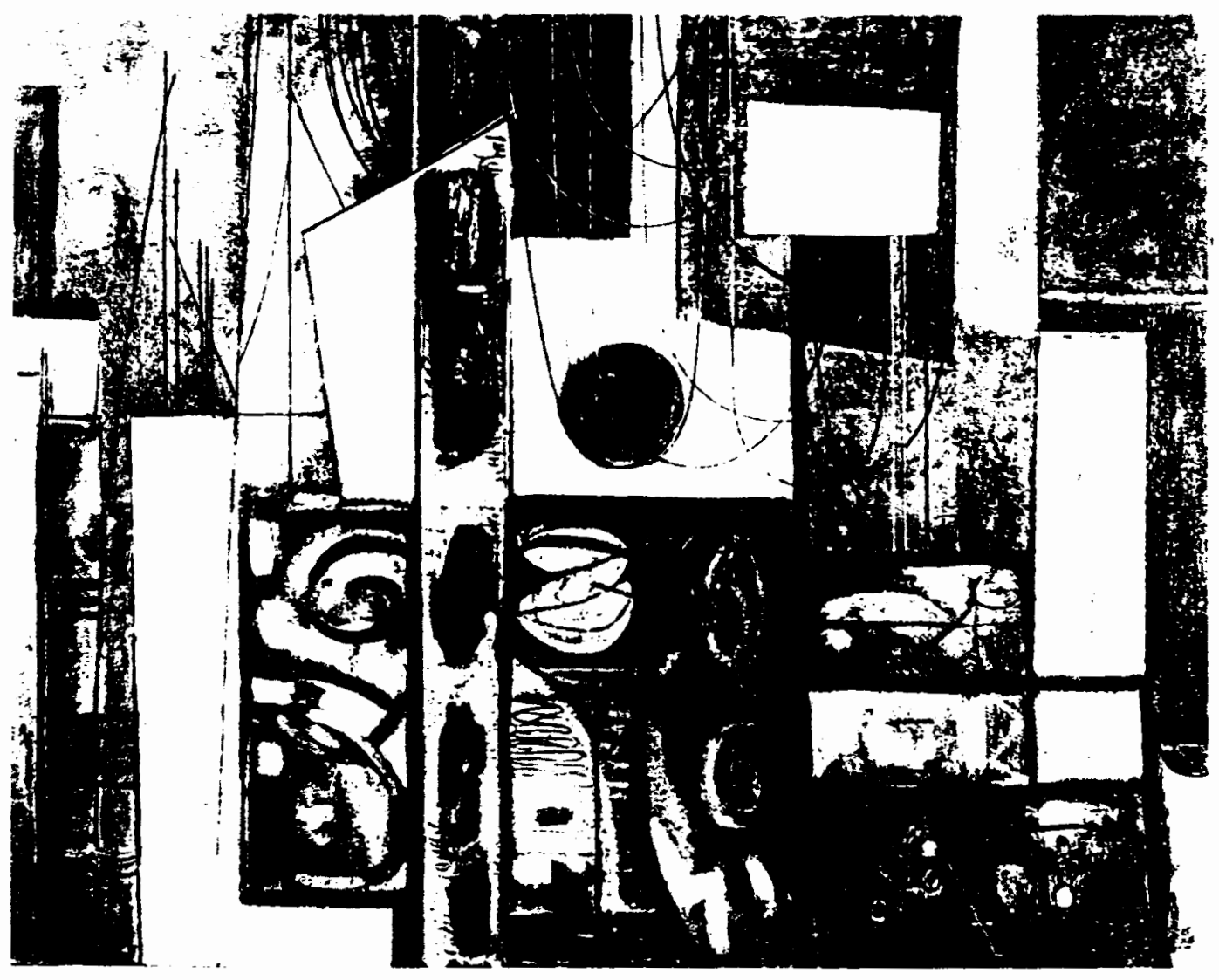


He also began, like many of the Abstract Expressionists at the time, to fill in the entire canvas. Cliffside, 1952-53, (Figure 10) is typical of Bunce's style of this period. The colors of the work reflect the browns, blues, tans, and oranges of an Eastern Oregon ravine. There is a small sliver of white in the upper portion of the work that represents the sky. Unlike the New York School artists of the time, there is a strong sense of depth and perspective. The overall effect of the piece is suggestive of analytical cubism, as if Georges Braque had painted the Snake River Canyon. Bunce said at the time:

I no longer pose form in a single space. Space, suggestive space, is much more evocative. Space is alive to the very edges of the canvas, with no single forms in space. The whole thing is space, and the forms suggest more space, a continuous space, expressionistic and abstract at the same time. The colors are sometimes soft, sometimes aggressive. 82

Bunce's explanation of his work sounds like art analysis given by the early cubists. His explanation is concerned with perspective and the subject. There is none of the self-awareness and transcendentalism that was associated with the New York School artists. There, action painters such as Pollock had abandoned the subject; while color field painters like Rothko attempted to stimulate emotions through shape and color. 
Figure 10: Bunce, Louis, Cliffside, 1952-53.

Rosenfield, Rachel. Louis Bunce, A Retrospective, exh. cat., (Portland Art Museum, 1979), P. 26, fig. 10 .

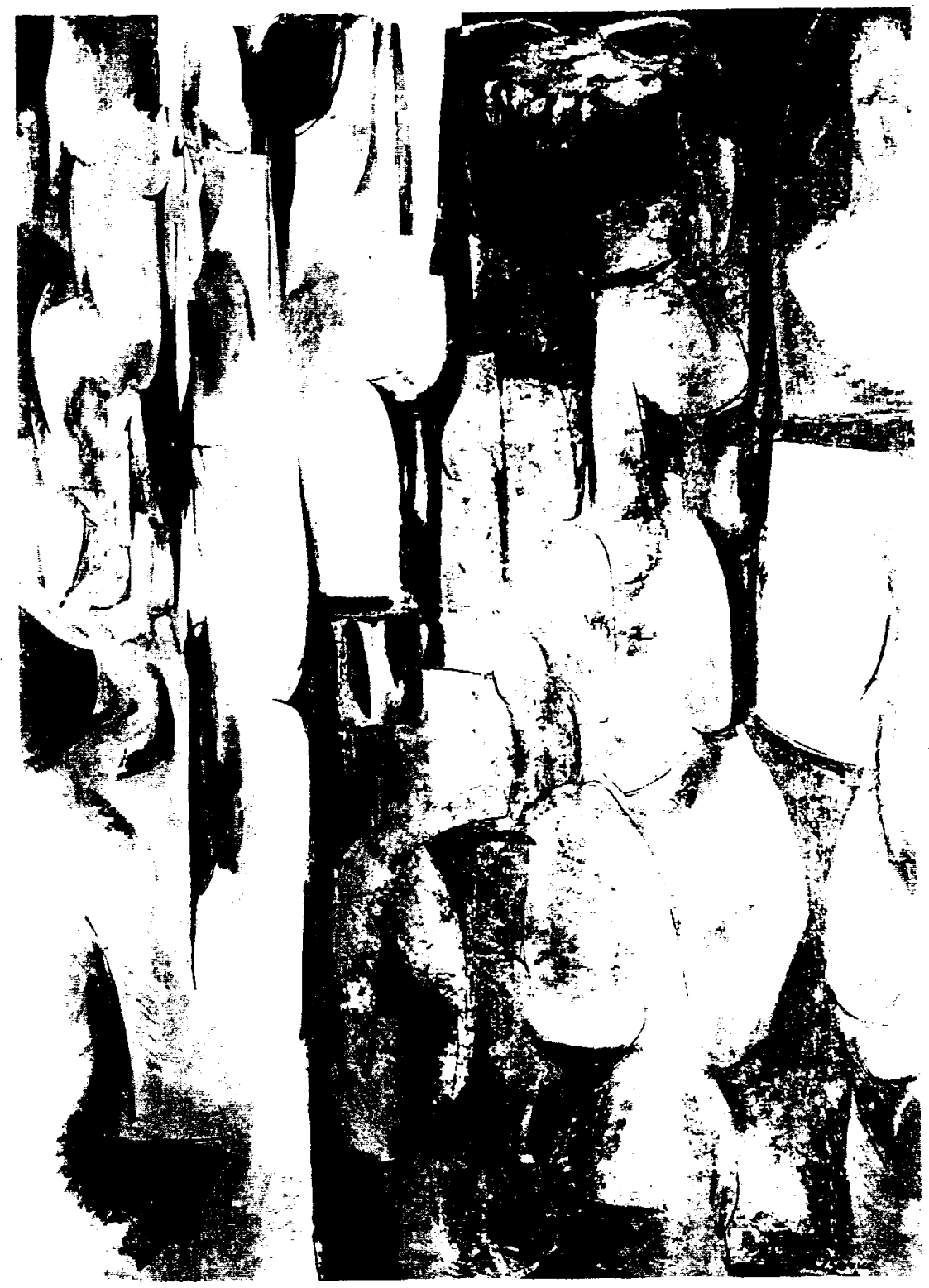


Bunce's work of this period reflects somewhat the influence of C. S. Price, the patriarch of Northwest Art. Price, born in 1874, had studied with Charles Russell, the famous "Cowboy Artist," at an art school in St. Louis. After a few years in Monterey, California, where he stayed in the former home of Robert Louis Stevenson, Price moved to Oregon. Price's early work was comprised of realistic scenes of farm life. By the mid-1930s, Price was painting in strong thick strokes suggestive of the 19th century American realist Albert Ryder and utilizing a Cézanne-like reduction of form* (Boats, Figure 11). By the time of his death in 1950, Price had reduced the subjects of his compositions to mere angular suggestions. In Horses in Landscape, 1948, (Figure 12) the title is the only clue to the viewer that there are horses in the mountain-like shapes. Price was the old master of Northwest art and Bunce undoubtedly had quite a bit of contact with him. Price established a style of abstractions of the Oregon terrain. After his death, Bunce carried on and further developed that style.

During the 1950s, Bunce had several shows in New York galleries. He showed at the Kraushaar, John Heller, and Meltzer Galleries and received favorable reviews from the New York press. ${ }^{83}$ In 1950 six of his paintings were shown in the Penthouse Gallery of the Museum of Modern Art and in 1951 he was included in a show at the Whitney. In 1955, Bunce was given a retrospective exhibit at the Portland Art Museum.

\footnotetext{
* Paul Cézanne (1839-1906) is widely regarded as the father of modern painting for his call to painters to rely on the "cylinder, sphere, and cone" to construct all artistic structures. ${ }^{83}$ Rosenfield, p. 22.
} 
Figure 11: Price, Clayton S, Boats, circa 1930

Cowels, Charles and Kingsbury, Martha. Northwest Traditions, exh. cat., (Seatle Art Museum, 1978), p. 88.

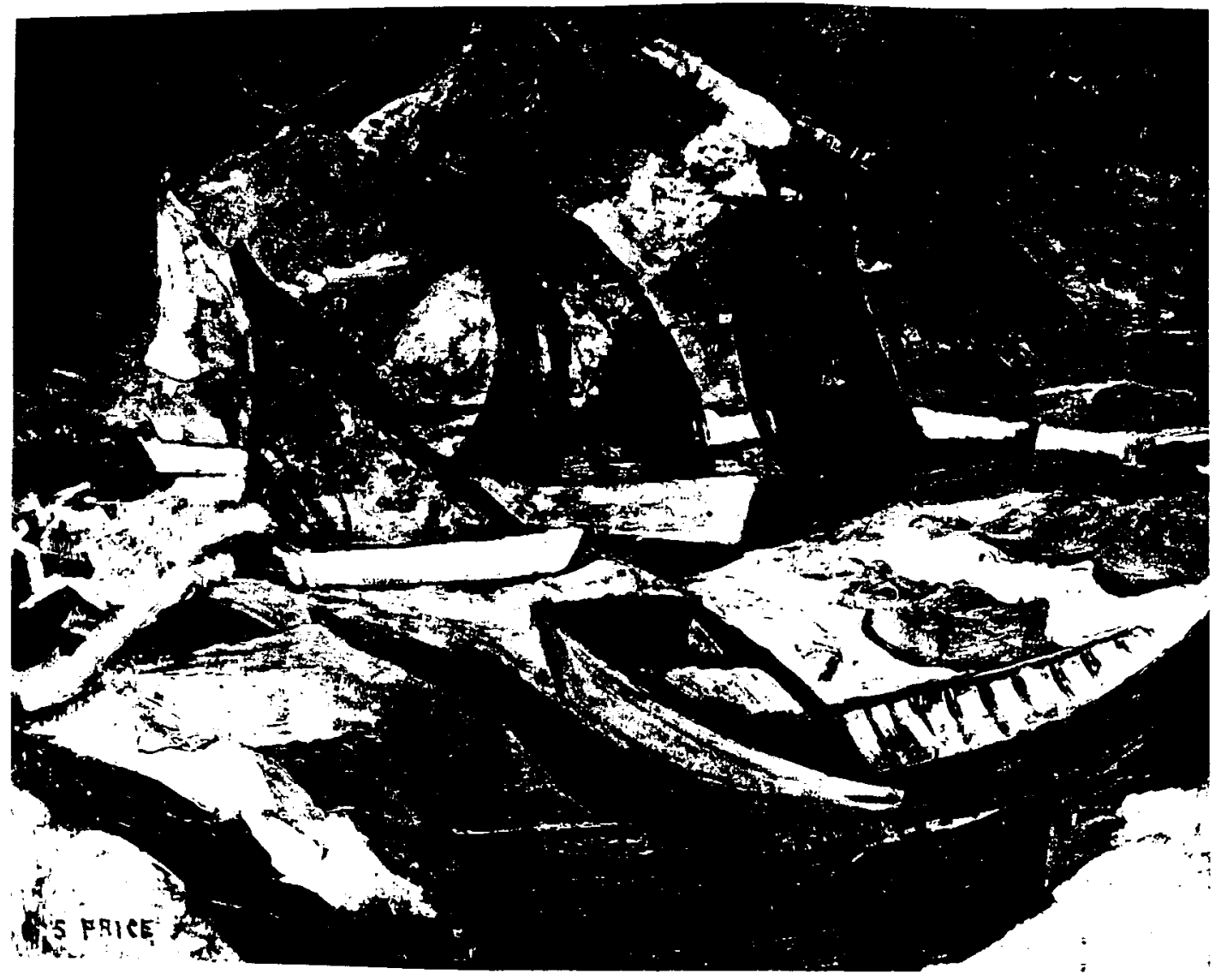


Figure 12: Price, Clayton S, Horses in Landscape, 1948

Cowels, Charles and Kingsbury, Martha. Northwest Traditions, exh. cat., (Seatle Art Museum, 1978), p. 24.

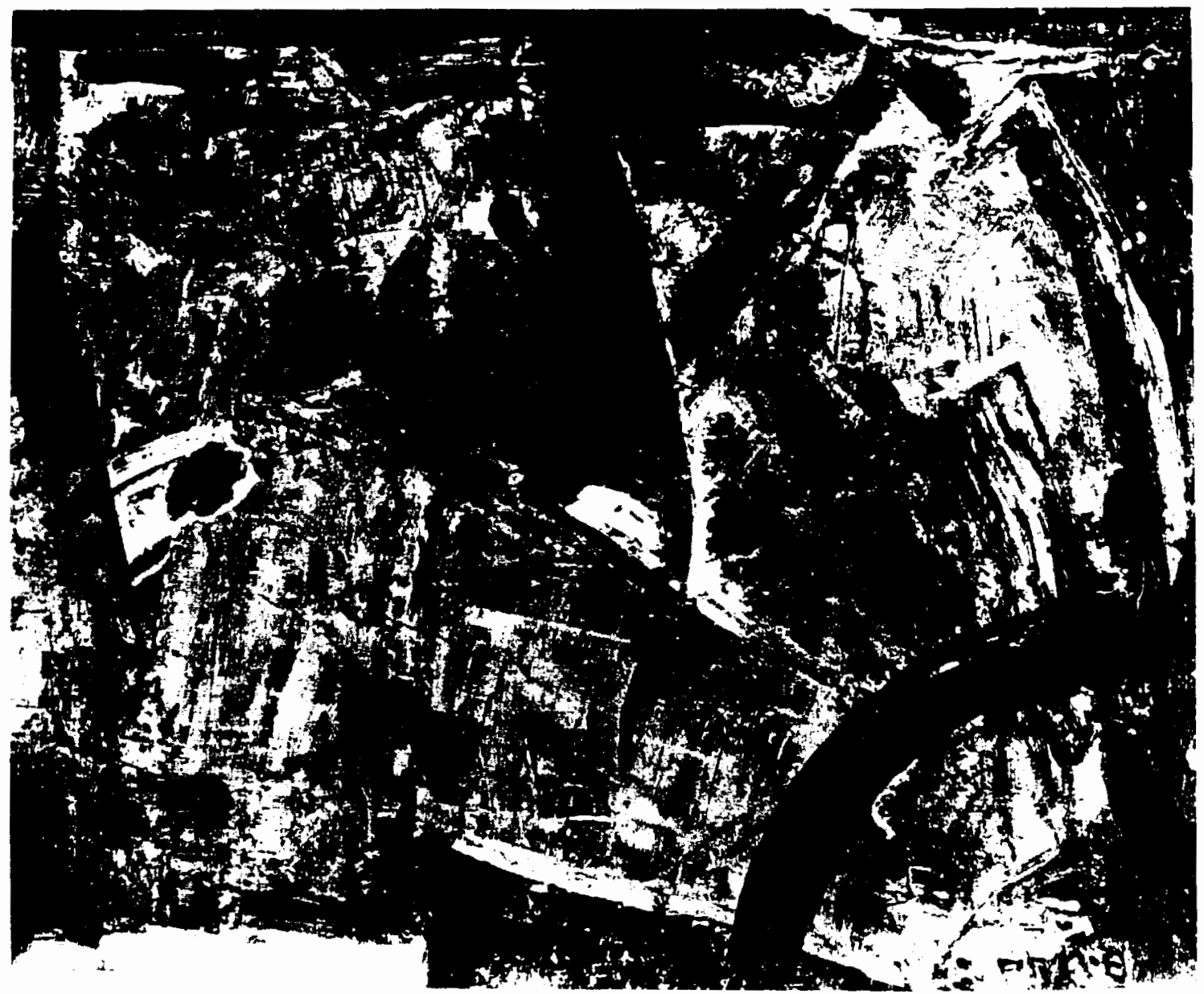


In the Fall of 1957, a Life magazine article on the art of the West featured four artists: Douglas Snow of Utah, Enrique Montenegro of Colorado, Robert Diebenkorn of California, and Louis Bunce of Oregon. The artists all painted in a broad expressionistic manner suggestive of their state's landscape. All four of the artists were pictured holding a canvas that was similar to a small photo of their state's landscape (Figure 13).

Bunce was shown holding Beach, Rising Mist . Like his paintings of the rugged Oregon mountains, this work suggestively outlines its subject. The ocean is alluded to in the far upper-right corner and the broad flat surfaces suggest strips of beach and rolling mist. In the left half of the painting an area painted with short choppy strokes is meant to represent the coast's rock formations. Bunce recalled later that the Life photographer asked him to identify the location of Beach, Rising Mist. Bunce replied that the painting was not of a specific location, but "reflected" impressions of many places on the coast. Bunce was later pleased and surprised that the photo that was used in the layout was close in spirit to the painting. ${ }^{84} \mathrm{On}$ the opposite side of the Life spread was Cliffside. Of the four artists featured, only Bunce was given two pages of coverage.

With his New York shows and Life feature, Louis Bunce was clearly the most prominent artist in Portland in 1958 -- he was the local boy who had been recognized by the East Coast art establishment. His selection as the muralist for the city's entry into the jet age seemed natural.

${ }^{84}$ Bunce, Louis, Oregon Historical Society Interview, p. 7. 
Figure 13: Life, "Art of the West" showing Bunce with Beach, Rising Mist. The oposite page featured Cliffside.

November 4, 1957, p. 68 - 69. Full color both pages.

ART OF WEST sontinuto

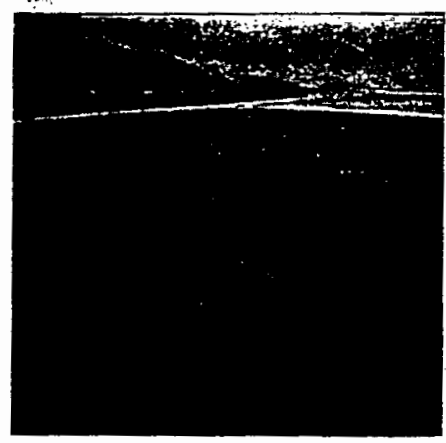

\section{SHIFTING IMAGES}

\section{FROM OREGON SHORE}

From the time he was 2 boy in Oregon, Loui Bunce liked to explore and atetch the cosacel regions near his home in Portlond. But is w'at not ustil he returned from a three.year stey in New York, where he absorlued the styles of ab. stract art, that he feit ready to incerpet the special moodand qualities of the Oregon cous. special moodand qualities of the Oregon caust. come and go of sea and sund, he cieaced peins. come and go of sea and sund, he crealed pains. ings like Beach, Rising. His (below) emphasiz. ing the shifting, elusive forms of rapors that drift over the oeesn and dappled shoals in aress like Cannon Beach (leffi). Though now in what he calls his "ses period," 50ryeat old Bunce also is inspired by the local wnode and eraggy revines (opposite) which he tramslatea into srangemens of simplified inieriocking shapa to sonvey an eifect of primeval solidity.

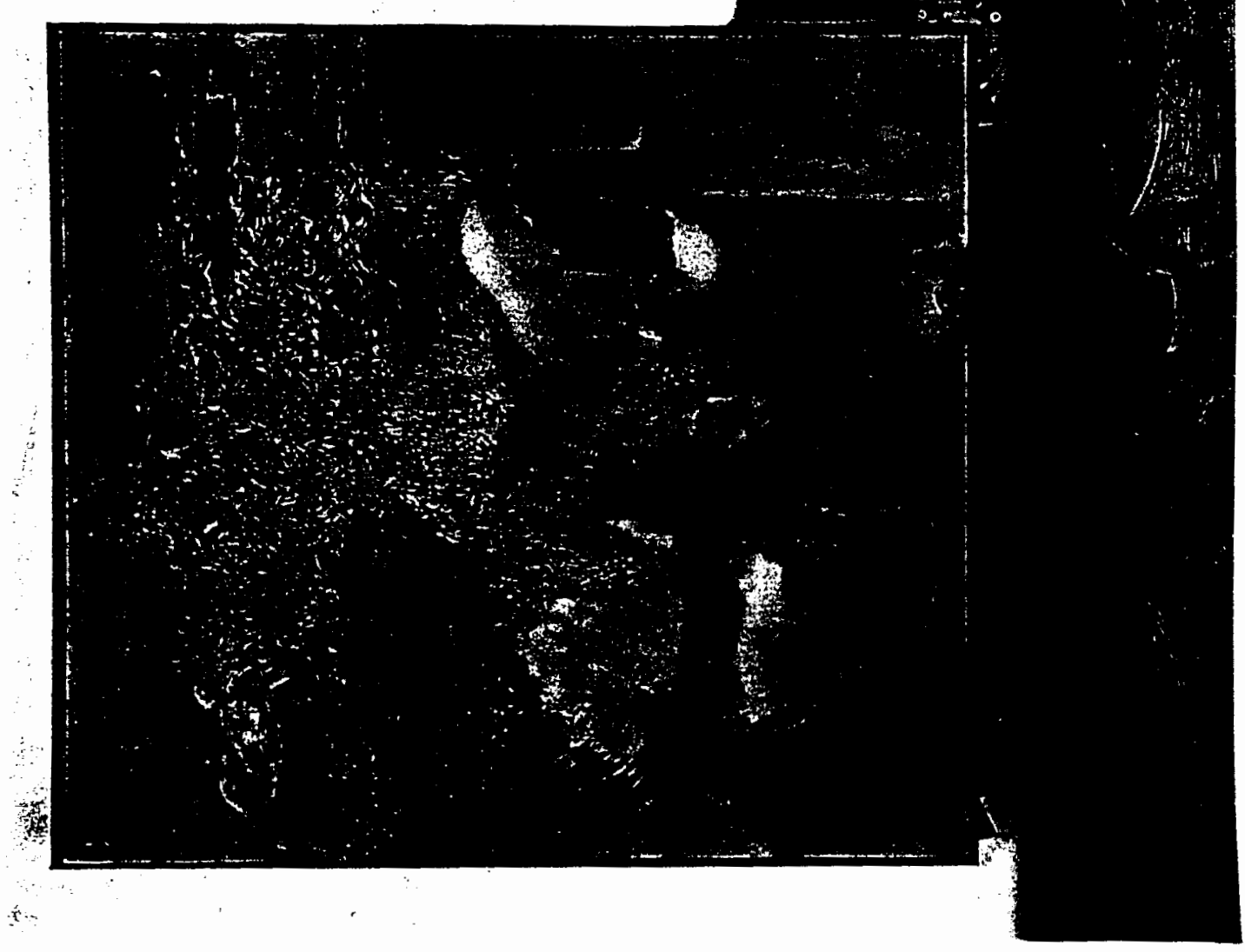




\section{The Controversial Mural}

In 1958 the Port of Portland was nearing completion of a new Terminal Building. The old airport terminal (Figure 14) built during the 1940s, was inadequate to handle the increase in air travel that had occurred since its construction. The new airport terminal designed in 1954 (Figure 15) was a dramatic International-style building. The architects had included a space in the terminal for a large mural. In late 1957, the architects asked the Port Commission to obtain an artist. The Port Commission decided that an open competition would be "too complicated" and delegated one of its members, L. Hawley Hoffman of Hoffman Construction, to serve as a "committee of one" to select an artist. Hoffman, then President of the Portland Art Association, first consulted with Max Sullivan, the Museum's director, and then quickly picked Bunce. Bunce was to be paid $\$ 300$ for a preliminary sketch, and $\$ 20$ per square foot for the final 11.5 by 20 foot mural.

The sketch for the mural (Figure 16) is similar to Bunce's other work from that period with its dramatic composition of cubist-like shapes. Unlike his paintings of mountain ravines and ocean beaches, however, there is no strong geological reference. Bunce painted Region (Figure 17) at about the same time. The similarity of the two works and the title of Region suggest that Bunce was expressing an overall impression of the Northwest in the mural sketch, perhaps even an impression of an aerial view of the region. 
Figure 14: Architect's sketch of the Portland Airport Terminal, circa 1940. Oregon Historical Society's Vertical Files: Portland Airport.

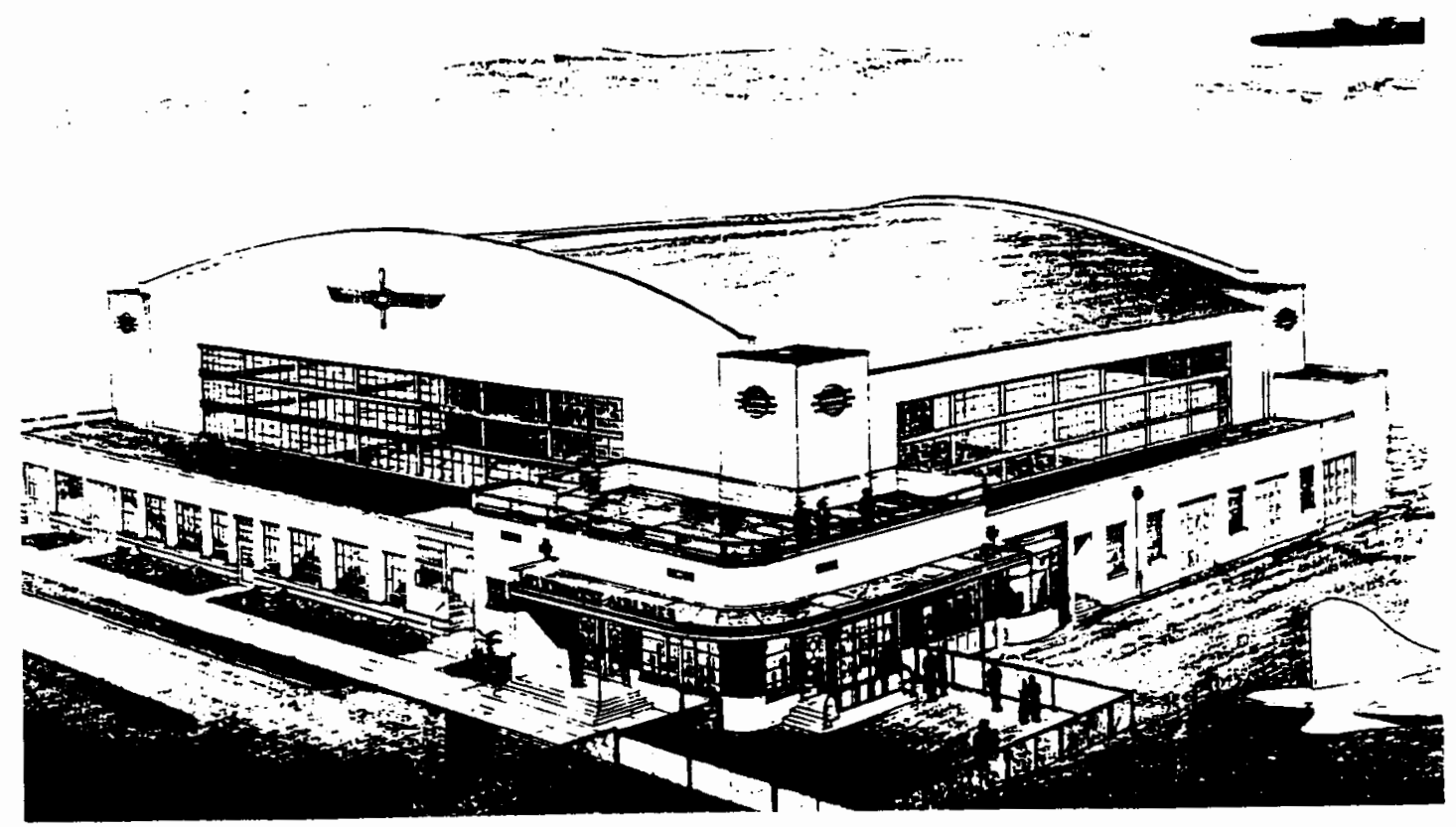


Figure 15: Architect's sketch for the Portland International Airport, circa 1954.

Oregon Historical Society's Vertical Files: Portland Airport.

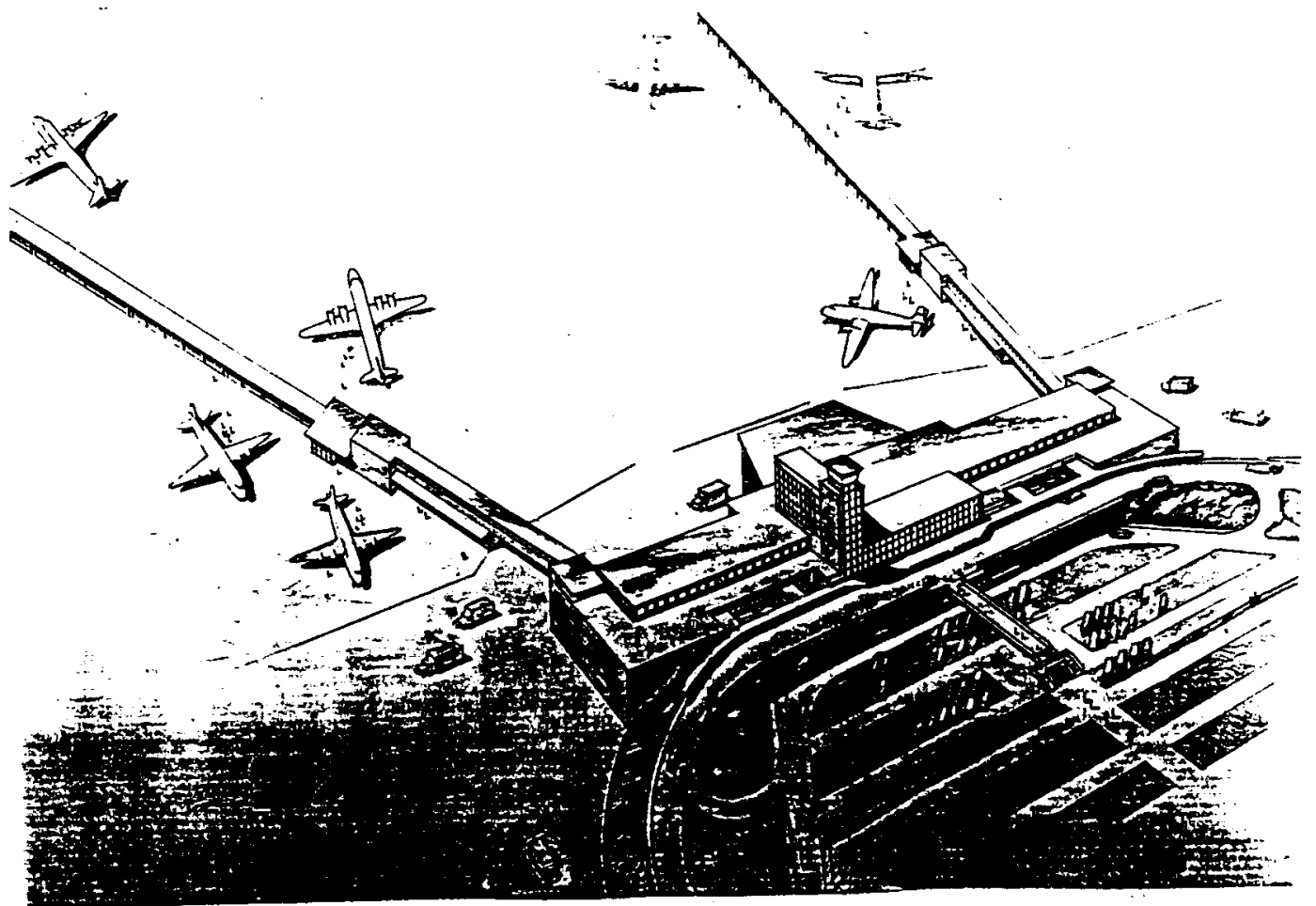


Figure 16: Bunce, Louis, Sketch for airport mural, 1958.

Rosenfield, Rachel. Louis Bunce, A Retrospective, exh. cat., (Portland Art Museum, 1979), p. 29 , fig. 12 .

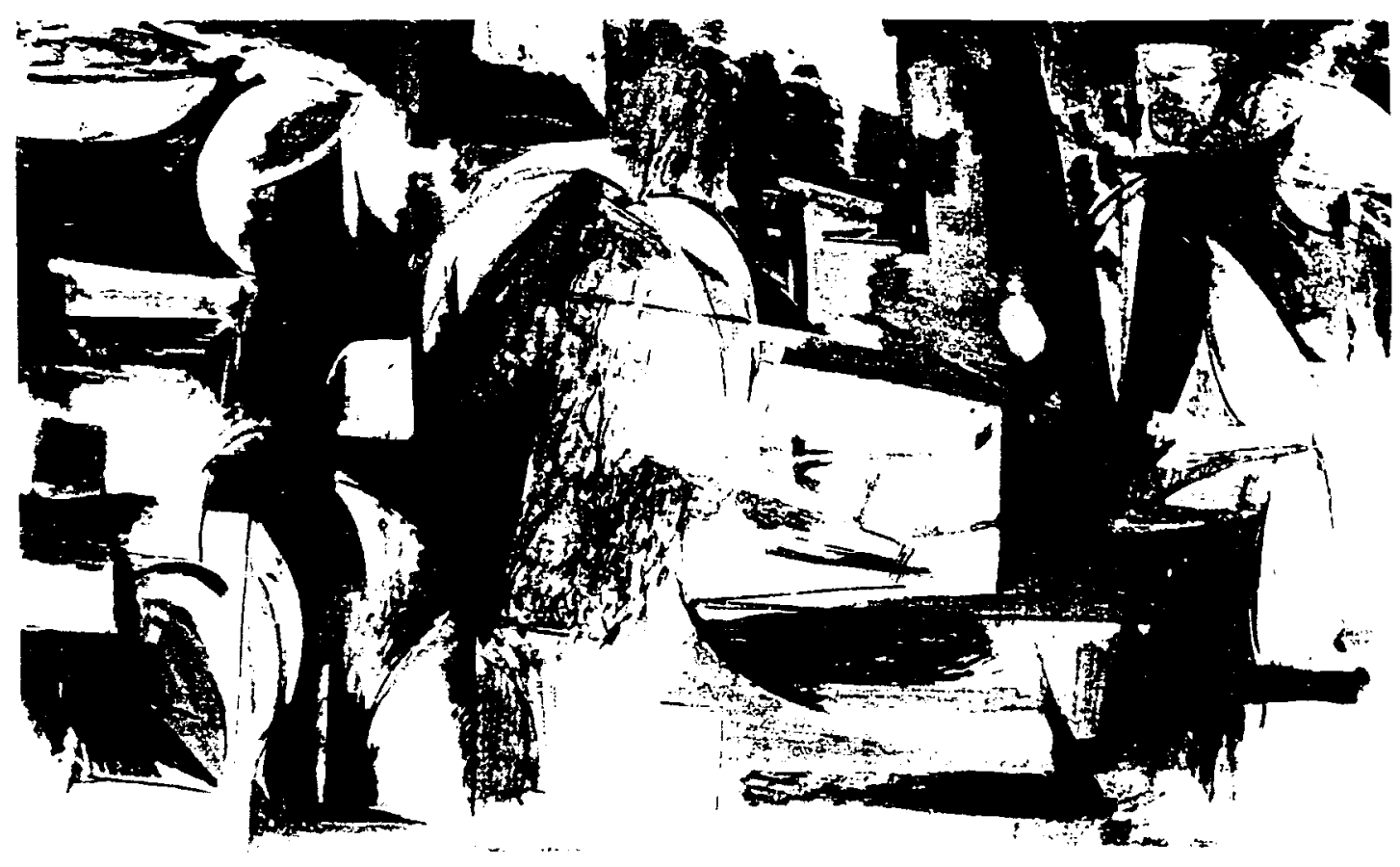


Figure 17: Bunce, Louis, Regions, 1958.

Rosenfield, Rachel. Louis Bunce, A Retrospective, exh. cat., (Portland Art Museum, 1979), p 25 , plate 4 .

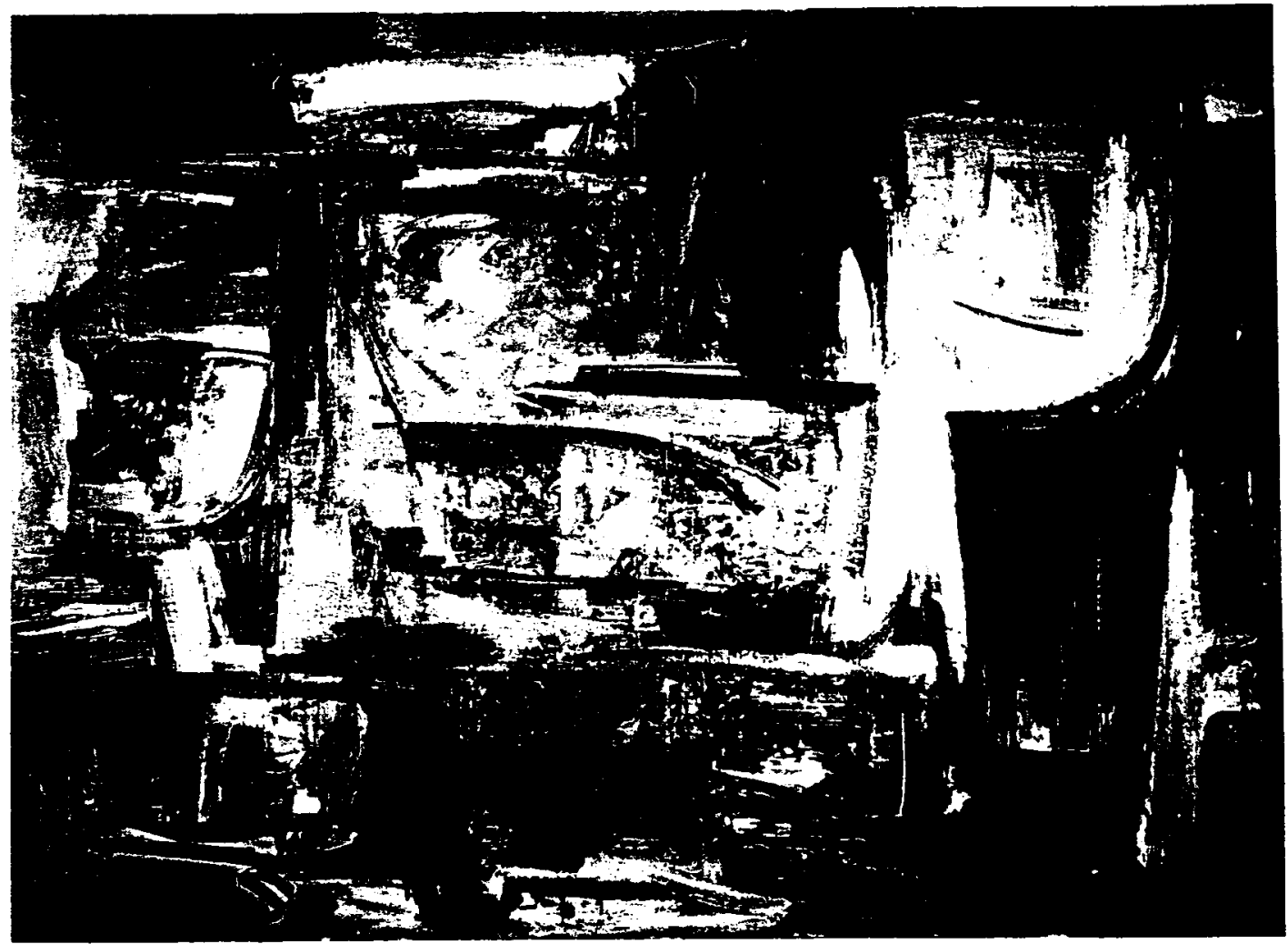


Bunce completed his sketch for the mural in early February of 1958 and delivered it to the Port of Portland's office on Monday, February 10. He was to meet with the Port Commission later that week. Someone in the Port office took the painted sketch into the boardroom and hung it on the wall. Unbeknownst to Bunce the Port Commission was meeting that very afternoon. Later Bunce was told that one of the commissioners walked into the room and exclaimed, "What in the hell is that?"85

A spectator in the room compared the piece to "The Tillamook Burn portrayed in scrambled eggs," 86 an ironic statement because the Tillamook Burn was the subject of several of Bunce's works that were shown at MOMA. Two of the commissioners, Dennis Lindsay, a local attorney, and Luke Roberts, a production manager for KOIN-TV, suggested that the mural would be a great conversation piece and that it would bring national attention to the Portland Airport. Unfortunately L. Hawley Hoffman was absent from this meeting. Hoffman had taken a leave of absence and was vacationing in Arizona. ${ }^{87}$ When the commission voted seven to one to rescind Bunce's commission, Dennis Lindsay was the only commissioner to support Bunce. Luke Roberts explained his own vote:

Personally I feel this is a fine piece of art, which would lend distinction to Portland. If you don't think the public will accept this then we have to go to cows or horses, or

85 Oregonian, "Louis Bunce - an Introspective Journey", (Jan. 19, 1975), NW Magazine, p. 4. 86 Oregonian, "Abstract art for airport declared to need score card", (Feb. 12,1958), p. 1, c. 2. ${ }^{87}$ Port of Portland Board of Commissioners Minutes, (Dec. 17, 1957), p. 81. 
timber, or mountains, or airplanes - something they can recognize. 88

The Commission instructed the director of aviation to investigate art that "everyone can understand." 89

Bunce learned of the Port's decision the next morning when the newspapers contacted him for a comment. When pressed to explain the painting Bunce said:

I tried to create a mural which would be as modern in concept as air travel and the building itself ... without specific type references such as airplanes, people, or buildings ... but incorporating a sense of space and movement ... something handsome as a decoration and yet reflecting these other things.

On Tuesday afternoon, January 11, The Oregon Journal featured a picture of the sketch on its front page with this headline above it: "Today: Yes, But What Is It?" The next morning the Oregonian also featured the Bunce sketch on page one with the headline: "Abstract Art for Airport declared to Need Score Card."

Bunce's supporters soon came to his defense. The following night the Portland Art Commission met and offered to help the Port "review" its decision. The Portland Art Commission had been founded by the City Council in 1955 with the express goal of selecting public art works. The commission, appointed by the mayor and comprised mostly of local businessmen, generally included one or two art community members

${ }^{88}$ Ibid.

${ }^{89}$ Oregon Joumal "Airport mural too modernistic", (Feb. 11, 1958), p. 1, c. 7. 
among its membership. The commission said that it had been contacted by Artist's Equity to take a stand on the controversy. The Portland Art Commission's vice-president, Mrs. D. V. Jennings, strongly chided the Port for making such a hasty decision. That same day Luke Roberts, the Port Commissioner who had supported the artist, said that Bunce would be given a chance to defend his work, and hinted that Bunce had told him that he was willing to redesign the mural but was "against some wellknown scene or something pastoral."90 Dennis Lindsay later remarked that Luke Roberts had been the most vigorous supporter of Bunce on the commission in Hoffman's absence. ${ }^{91}$ The following Thursday morning, the editorial column of the Oregonian called for the reconsideration of the Bunce mural..$^{92}$ The paper supported the position that the Port delegate its decision to the Portland Art Commission, suggesting that the Port would not dream of building a airport without the guidance of architects and engineers and that "its venture into decoration deserves the same precautions." 93

A Oregon Journal editorial echoed the Oregonian position the next day. In the Sunday Oregonian Bunce was given a full-page feature, unprecedented for a Northwest artist. The paper's layout showed a

90 Oregon Journal, "Port group may reconsider painting rejection, Art group offers services, Louis Bunce artist", (Feb. 13, 1958), p. 9, c. 1.

91 Lindsay.

92 Oregonian, "Gateway Art", (Feb. 13, 1958), p. 18, c. 2.

${ }^{93}$ Ibid. 
miniature version of the Life magazine spread on Bunce with the national magazine's logo prominently reproduced. A picture of a Hans Hoffman mural was shown to illustrate that "in New York building owners want unusual work."94 The accompanying article recounted Bunce's positive reviews from New York critics (including Henry McBride and Dorothy Adlow) in an effort to show that:

Bunce, who has lived in Portland for 35 years is not a capricious dabbler carelessly tossing paint on a canvas, but a top regional artist of national and international stature. . . art museums and wealthy collectors have backed their praise by paying out hard cash for his output. 95

On the next Wednesday, Bunce met with the Port Commission and told them that he wasn't there to defend his sketch, but that the final mural might differ because of problems that could arise from working in a larger scale. Several others spoke at that meeting. Frederick Jensen, a Portland real estate agent who represented the "freelance map and aviation painter" Alfred Owels, volunteered his client's service. Cahot Therkelsen spoke to protest the involvement of the Art Museum, a "group that only represents its 1800 members' minority taste." Therkelsen warned that "people taking airplane rides are going to be greatly shocked" by the mural.96 A staff member from the Port reported that they had received 12

${ }^{94}$ Oregonian, "Space conflict! Port ponders the world of abstract art, Louis Bunce mural for", (Feb. 16, 1958), p. 28, c. 1.

95Ibid.

96 Oregon Journal, "Port asks help of art arbiters", (Feb. 20, 1958), p. 11, c. 7. 
offers by artists to produce a mural. The meeting concluded with the six Port Commissioners present voting to refer the matter to the Portland Art Commission. The Portland Art Commission was given three weeks to report back to the Port.

On March 7, the Portland Art Commission held a public meeting and announced its recommendation to the Port that Bunce should not only be given the commission but also the full freedom "in the development of the painting." 97 The art commissioners repeatedly stated that the only way to create meaningful art was to give the artist his freedom. John O. Merrill, Jr., an architect, said anything pictorial at the airport would be "miserable." 98 John Blew, president of the Art Directors Club, reminded the group that only 20 years prior some of C. S. Price's paintings had been deemed unsuitable for the Timberline Lodge. The highlight of the Art Commission's meeting occured when it was discovered that Bunce's sketch was shown upside down. ${ }^{99}$

Monday, March 11, the Port of Portland met to consider the Portland Art Commission's recommendation. The Oregonian reported that "thirty art students and teachers from the Portland Art School and Reed College,

97 Oregonian, "Art groups warmly recommend controversial mural", (Mar. 7, 1958), p.1, c. 2.

98 Ibid.

${ }^{99}$ Ibid. 
some of them sporting beards,"100* appeared at the meeting. With little debate, the Port voted to accept the Art Commission's recommendation with only one dissenting vote. That vote was by Lee Caldwell, the representative of the United Steelworkers.

Bunce started work on his mural, but the flurry in the newspapers continued. Letters to the Editor columns were filled with angry condemnations of the Port's decision while the editors themselves praised the Port and the artist. In May, the Oregonian published a article by Meyer Levin, "an art critic and best-selling author," that commended the selection of Bunce and offered a historical review of other notable art controversies. Meyer especially was bemused that the Port had chosen to pay Bunce, "an artist of international stature," less than five thousand dollars. Levin suggested that the Port really didn't know the value of art and that Bunce should receive a bonus. ${ }^{101}$

Bunce painted the final mural in a large gallery at the Museum because the piece was too large to paint in his studio. 102 Jack McLarty remarked that it was interesting to watch Bunce paint the large canvas because he used the small strokes of a easel painter rather than the bold

100 Oregonian, "Bunce gets free hand from Port (additional details on p. 12.)", (Mar. 11, 1958) p. 1, c. 1 .

* Italic highlight added by author.

${ }^{101}$ Levin, Meyer, Oregonian, "Critic Applauds Louis Bunce's Abstract Mural, Suggests bonus for Portland Artist", (May. 10, 1958), p. 1, c. 1.

102 Bunce, Jon. 
stokes generally associated with large abstract expressionist canvases. ${ }^{103}$ The Oregonian reported that the canvas for the piece had to be specially ordered from New York. ${ }^{104}$ In June, both of Portland's daily papers showed Bunce hard at work on the mural (Figure 18). On August 7, the mural was unveiled at the airport (Figure 19). Again, the local newspapers praised Bunce's "Visual World."105 The mural's canvas was adhered to the wall of the airport terminal with lead white paint. ${ }^{106}$

The final mural (Figure 20) departs dramatically from the small unrecognizable planes and angles of the sketch. The final piece is far more geometrical and all of the lines and angles are considerably more defined. When he finally was awarded the commission by the Port, Bunce had hinted that the final version might incorporate recognizable forms such as the rudders and wings of an airplane. ${ }^{107}$ Bunce did incorporate some airplane-like structures into the work. There are geometric forms that vaguely suggest airplane components. Some of the geometric planes in the mural seem solid and static, while others are subdivided and bisected and lend a sense of Futurist dynamism. In the upper right hand corner of the

103 McLarty.

104 Oregonian, "Airport mural nears completion (additional pictures on page 5)", (June 21, 1958), p. 1, c. 1.

105 Oregonian, "Louis Bunce Mural has first Viewing at Airport", (Aug. 7, 1958), p. 1, c. 1.

${ }^{106}$ Bunce, Jon.

107 Oregonian, "Bunce gets free hand from Port (additional details on p. 12.)", (Mar. 11, 1958), p. 1 c. 1. 
Figure 18: Oregonian photo of Bunce at Work.

Oregonian, Jan. 19, 1975, NW Magazine, P. 4, "Louis Bunce an Introspective Journey".

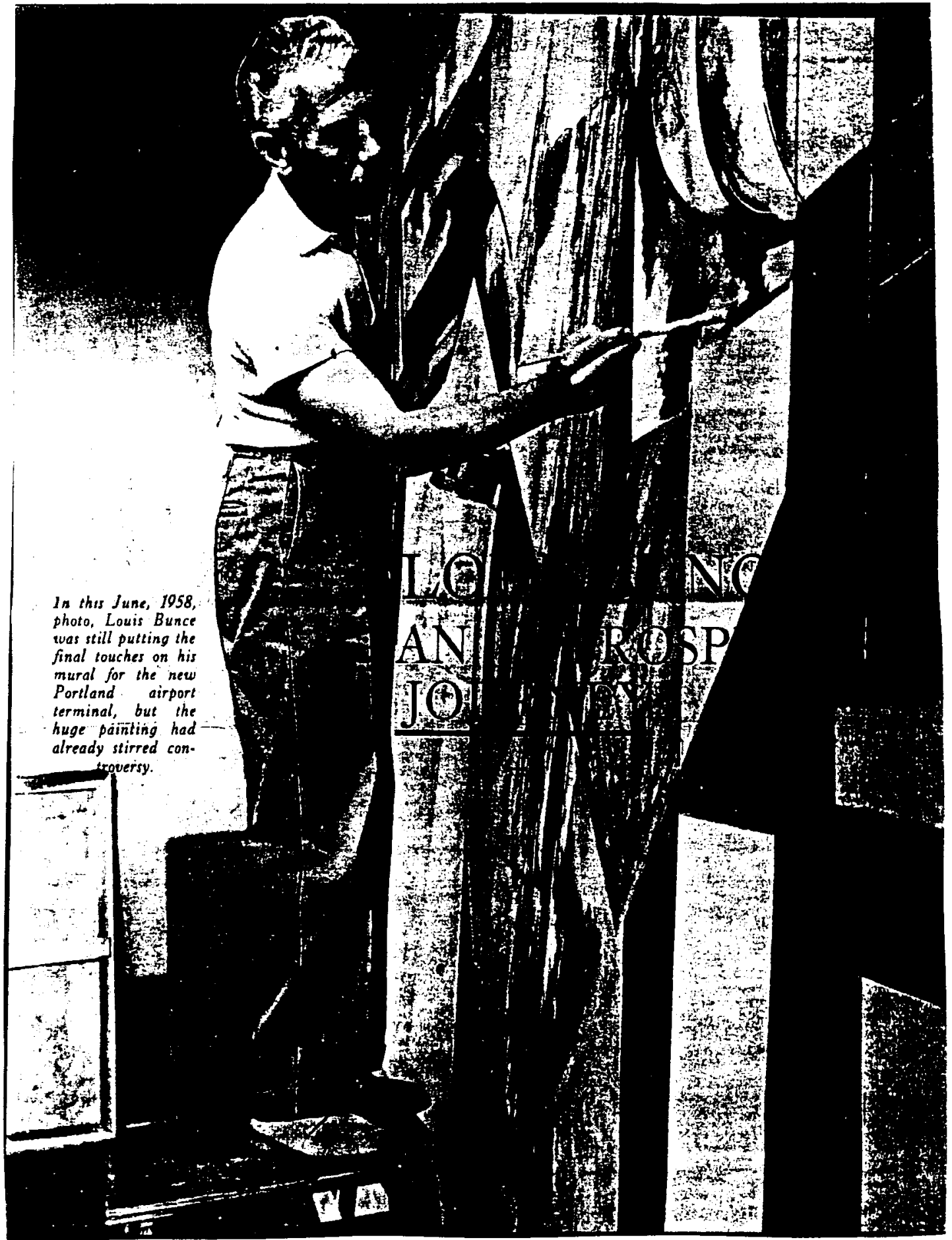


Figure 19: Oregonian photo of the airport and the mural.

Oregonian. August 7, 1958, "Louis Bunce Mural has first Viewing at Airport".

\section{Louis Bunce Mural Has First Viewing at Airport}

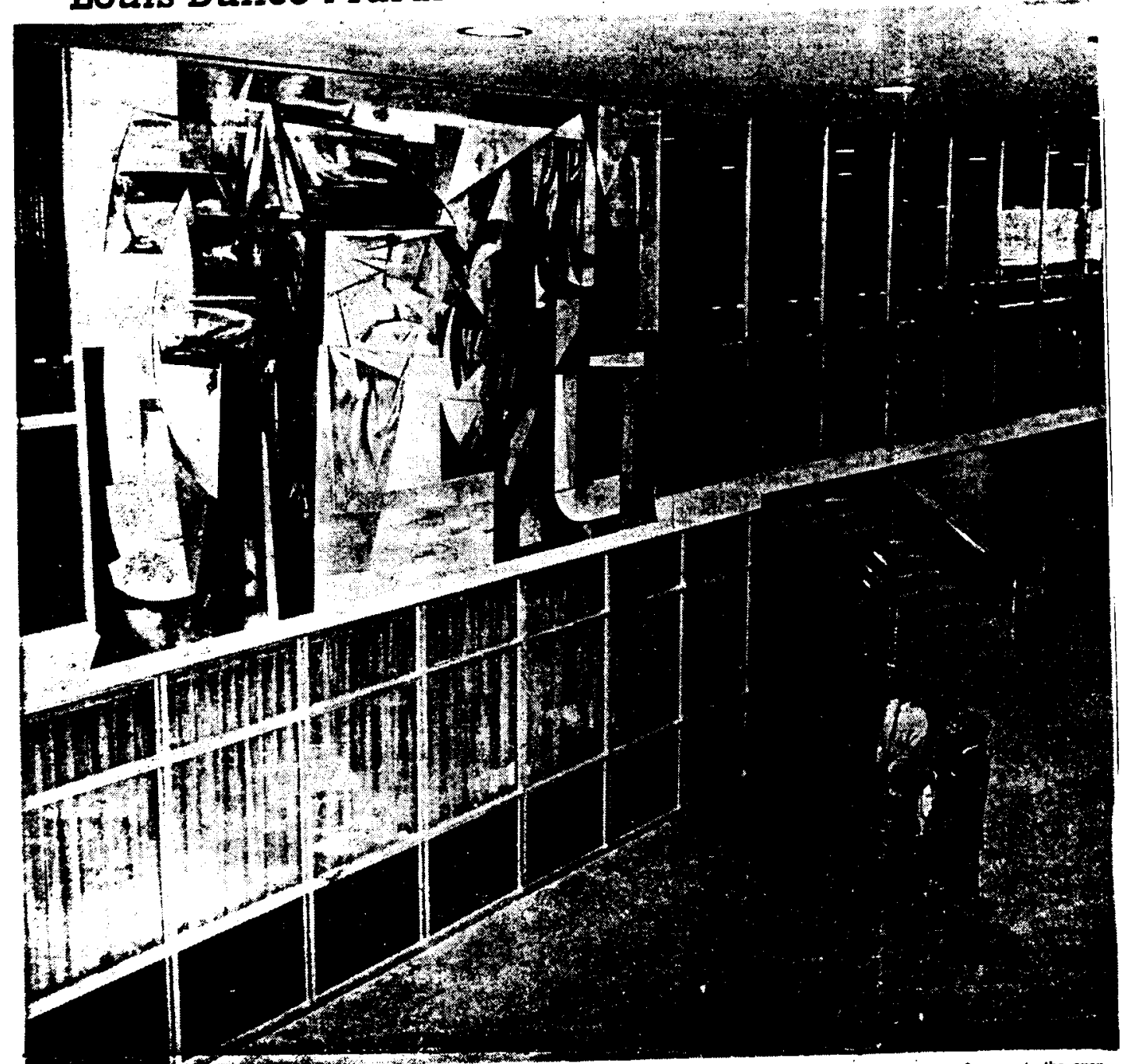

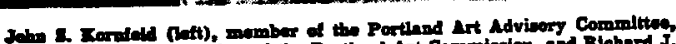

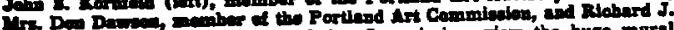

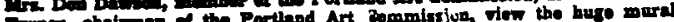

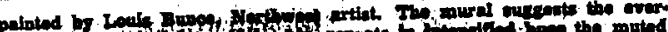

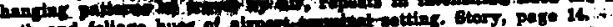




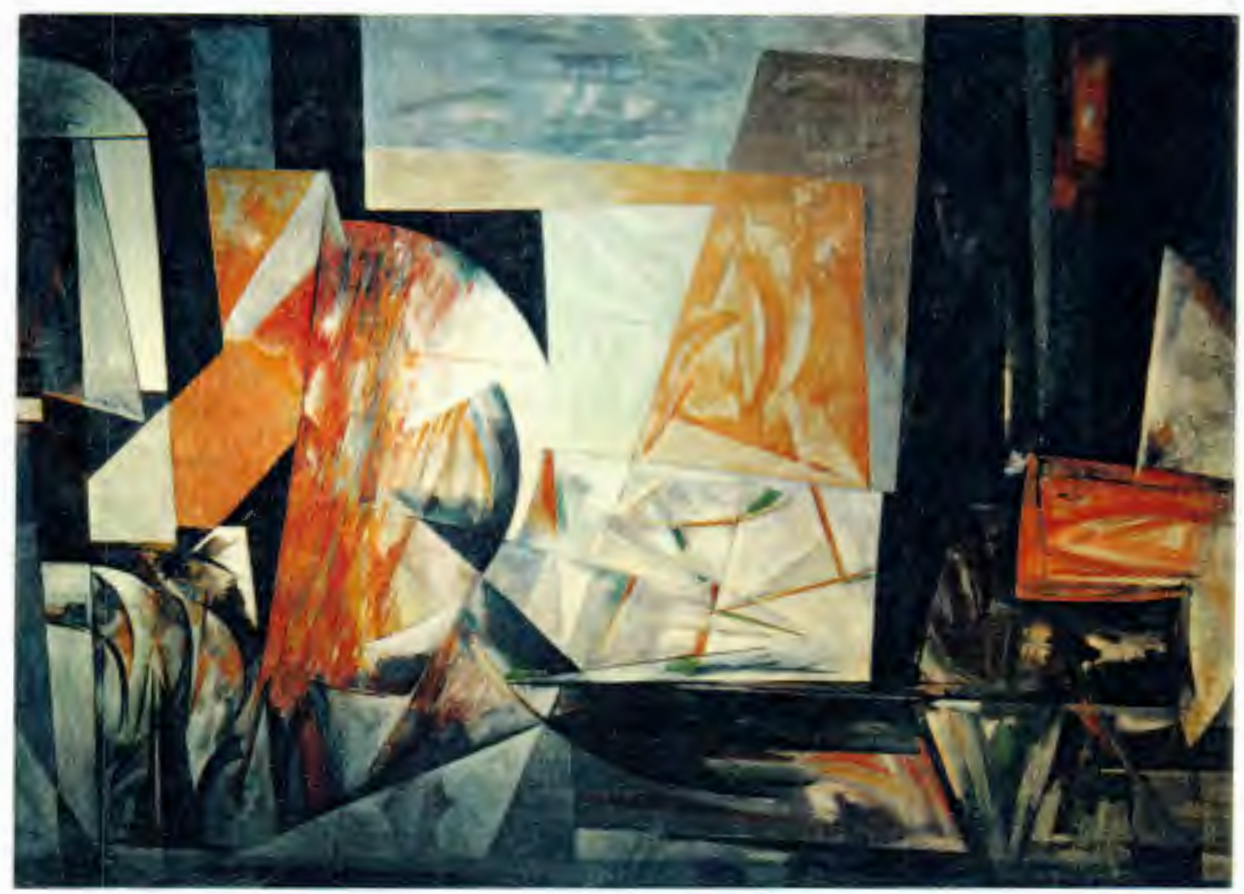

'966L '0704d s,Io4nin

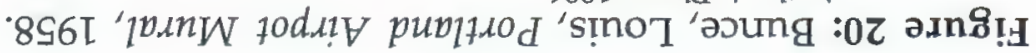


piece are a pair of bird-like shapes that are reminiscent of the birds in his works during the 1940s (see Figure 8). It is almost as if the birds are perched on the rock formation of a dappled cliffside. The colors in the mural are suggestive of the colors of steel and iron, both new and rusted. Perhaps this was an allusion to the metal of the wartime shipyards or to new aircraft.

If the Port had anticipated a more representational work than the original sketch, what it received was a piece that was easily just as abstract. It is only with considerable familiarity with the painter's previous work that one can attribute the particular shapes and colors to concrete objects and it is only with an understanding of Cubist and Futurist idioms that one can attribute motion and movement to the various components. Bunce's son Jon has said that the title of the mural was Flight, a title that does provide a clue to the casual observer of the dynamic aspects of the work. ${ }^{108}$ However, this title was not mentioned in any of the newspaper descriptions of the work, and there is no evidence that Bunce shared this title with anyone outside of his family. Jack and Barbara McLarty both said that Bunce must have felt he was "carrying the banner for abstraction."109 Bunce's failure to make public the title of the painting only strengthens this assertion.

The unveiling of the mural heightened the fury in the local newspapers. Letters to the editor ranged from the serious to the quick "cheap shot" at the muralist and the Port. One hostile critic complained

${ }^{108}$ Bunce, Jon.

${ }^{109}$ McLarty. 
that the painting looked like a "DC-6b splattered over a hillside." [A naive criticism, but one that is actually very insightful.] Another wrote to declare that everyone had neglected the great public service that Bunce had provided:

I too have seen the mural and am fully convinced that if anyone can study it seriously for even 10 or 15 minutes without experiencing a deep internal feeling of gastric upset, he need not worry about the need of dramamine for the rest of his flight. 110

Letters in support of the mural were also received. Barbara McLarty recalled that she felt compelled to write a letter when she read a letter proposing that the Port commission Stuart Holbrook to paint a Mr. Otis painting for the airport. 111

On October 15, Bunce was sufficiently offended by a letter from Rabbi Julius Nodel that he responded with a letter to the editor. Nodel had written that he could not make sense out of the Bunce mural and concluded that modern art was a big joke. Bunce wrote:

I have been reluctant to waste the dialectical verbiage needed to answer the many inane letters which have appeared almost daily in the Oregonian since the inception and conception of the terminal mural. However the letter of Rabbi Nodel deserves serious attention in that he is a leader and spiritual voice of a large group of intelligent people in the community. . He admits his own

110 Oregonian, "The Peoples Own Corner: Mal de Mural", (Oct. 15, 1958), p. 38.

${ }^{111}$ McLarty. 
limitations of artistic judgment, but immediately takes on the role of informed critic and aesthetician. ${ }^{112}$

The editors in the column opposite "The People's Own Corner" announced that day that they would no longer publish letters regarding the mural. "There are some things such as Elvis Presley, limburger cheese, and the sack dress, of which readers either approve or disapprove. . In this category we place abstract art."113

Bunce later reported that the abuse was not limited to the media flurry. He received threatening phone calls, had rocks thrown at his house, and had garbage dumped on his lawn. ${ }^{114}$ Bunce's friends and family later said that Louis thrived on the attention from the controversy but also found it a bitter experience. ${ }^{115}$ Bunce said that the experience helped raise Portland's art awareness, but it also made him realize that he "had no real professional status as an artist. Society can treat you like -- well, compare you to all sorts of strange things - to a chimpanzee that paints."116

112 Oregonian, "Mr. Bunce Replies", (Oct. 15, 1958), p. 38.

113 Oregonian, "The End", (Oct. 15, 1958), p. 38.

${ }^{114}$ Bunce, Louis, Oregon Historical Society Interview, p. 5.

${ }^{115}$ Bunce, Eda; Bunce, Jon; Gilkey; and McLarty.

116 Oregonian, "Louis Bunce - an Introspective Journey", (Jan. 19, 1975), NW Magazine, p. 4. 


\section{Continuing Controversy}

In November of 1958 Bunce was once again in the news. He had been hired to paint a $12 \times 20$ foot mural at a donut shop in downtown Portland. The "Doughnut" mural (Figure 21) was markedly different from the airport mural. The piece is similar to the cityscapes in Bunce's early surrealist and cubist works. Léger-like abstractions of the city and the mountains are interspersed with familiar Portland landmarks: the Skidmore Fountain, a Benson drinking fountain, and the Main Street Elk. After the donut shop closed, the painting was rescued and stored. It was purchased by John Booth and later given to the City. ${ }^{117}$ It now hangs in the Georgia-Pacific room at the Memorial Coliseum. Bunce also created a mosaic of tiles on the side of a tile store in Milwaukie, Oregon for which Bunce and the store's owner received the brief attention of the local press. 118

In 1959 a new art controversy began that once again involved Bunce. That year the State of Oregon celebrated its Centennial with an exposition at the Multnomah County Exposition Center near Delta Park. The exposition, which was to run for most of the summer months, had contracted with Bunce, Carl Morris and other artists to alter the fairground buildings of the Expo Center. Bunce was selected to paint a mural on the side of the horticulture building. Bunce's mural was to be located between

117Widman.

${ }^{118}$ Bunce, Jon. 
the "Garden of Tomorrow" and the midway rides.119 In April the Centennial Commission accepted Bunce's sketch. The sketch (Figure 22), full of biomorphic shapes representing bugs and vegetables, is very much like Bunce's earlier synthetic cubist works. The murals by the various artists were painted on plywood which was then bolted to the barnlike buildings at the Expo Center. The cost of the total mural project was $\$ 25,000$. Bunce was paid $\$ 2,500$ for his $22 \times 32$ foot portion. As could be expected, news of abstract murals provoked a reprise of the airport controversy. Portland's two dailies were once again full of letters to the editors protesting the expenditure of public money on abstract art. A large photo of the soon-to-open exposition appeared on the front page of the Oregonian on May 27 (Figure 23). While the photo does not show Bunce's horticultural mural, the other murals were all in the same spirit as Bunce's.

Mrs. C. G. Murphy, known as "Dell," took particular offense at the proposed murals. Dell's husband Chester Murphy was an artist (Gordon Gilkey describes him as a "fairly decent representational watercolorist"120) and was a member of the Oregon Society of Artists (O.S.A.).

In April of 1959, Mrs. Murphy and a small group of "six or eight people... housewives and businessmen with an interest in art"121 met to

119 Oregonian, "Latest Bunce painting unveiled", (July 14, 1959), p. 5, c. 3.

${ }^{120}$ Gilkey, Gordon, unpublished interview with Michael P. Craven, (1996), unpaginated.

${ }^{121}$ Murphy, Mrs. Chester G., Summary of Activities, Citizens for Art, 1959. (Author presumed to be Mrs. C. G. Murphy: Circa 1960). 
Figure 21: Oregonian or Oregon Journal photo of Bunce signing the "Doughnut Mural" - circa 1976.

Portland Art Museum Library's Vertical Files: Louis Bunce.

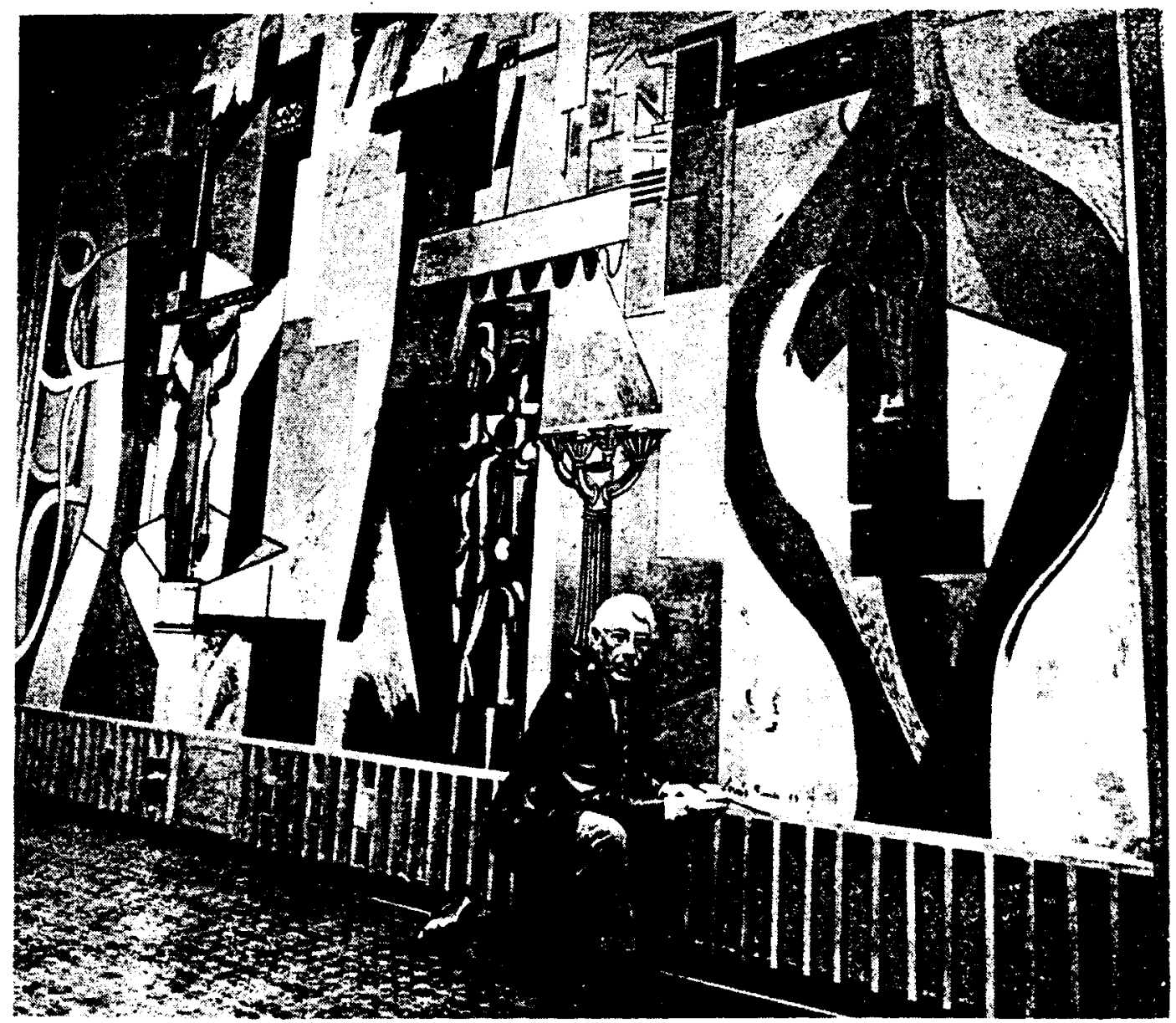


Figure 22: Oregon Journal photo of Bunce's Mural for the Centennial Expo.
Oregon Journal, April 28, 1959, p. 1, "Bugs and Flowers Join Centennial Art".

\section{'Bugs and Flowers' Join Centennial Art}

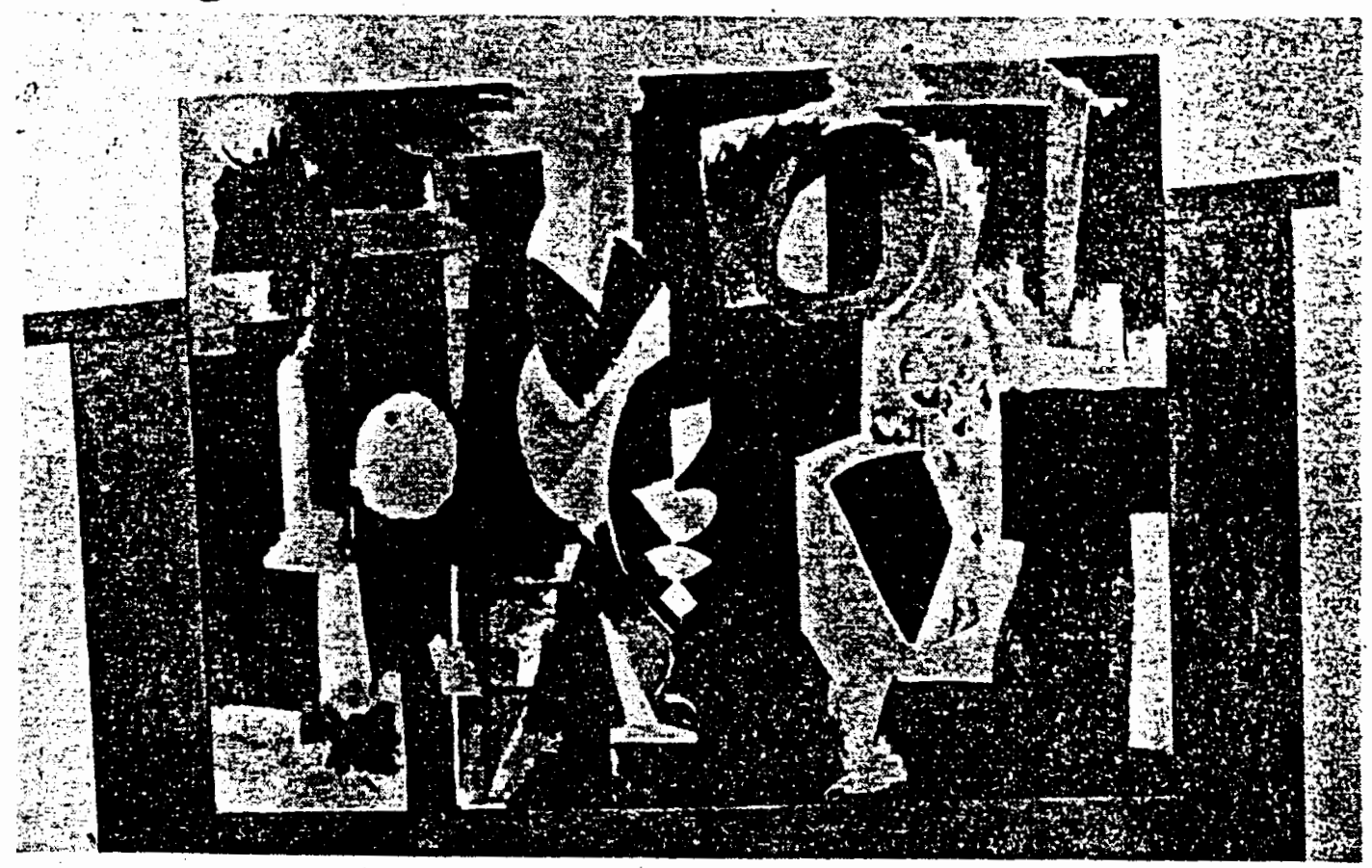

REPRESENTATIONAL?' No, but Centennial commission sald model of large Louls Bunce mural for horticultural

bullding is fust what it wanted anyway. Bright, warm colors dominate. Shapes represent leaves, flowers-and bugs. 
Figure 23: Oregonian photo of the murals by various Northwest artists. Oregonian, May 27, 1959, p. 1, "Mural, Frontier Billage Show Centennial Home-Stretch Progress".

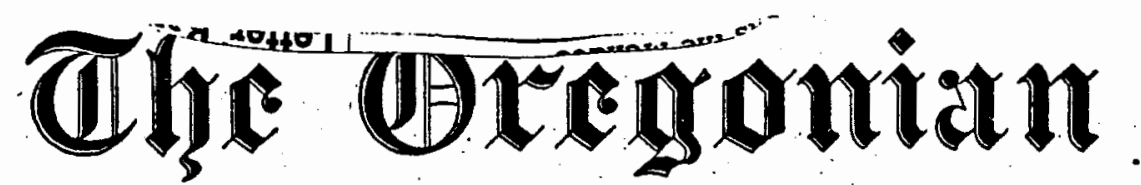

Iin

\section{Mural, Frontier Village Show Centennial Home-Stretch Progress}

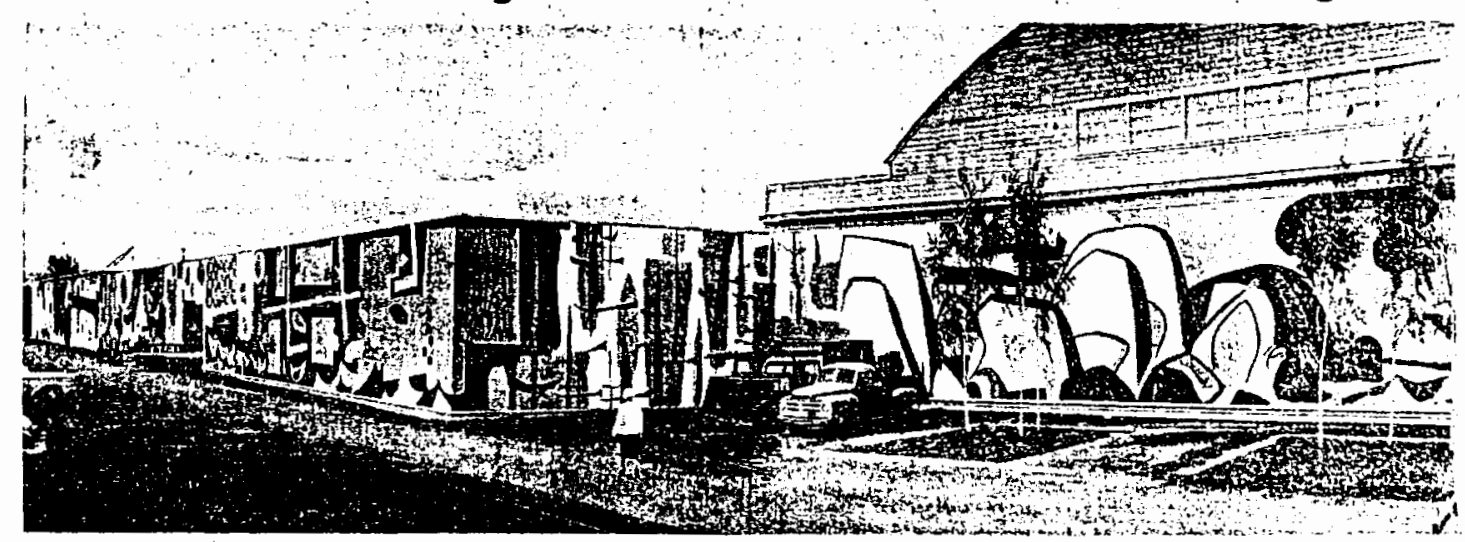

Mits cleat, bright-eolored, lmpressionistic mural covering enat ond af Centonnial Fxpoix. ton Building probebly will gooerato mired foelines among the thouravds wo vipw it 
discuss the abstract murals and their frustration with the Centennial's art show that was planned for the summer. The group felt that the jurors for the exposition's art show were too biased in favor of abstract art. Most of the works by the O.S.A. artists were not to be included in the show. O.S.A, while deeply resentful of the Portland Art Association and the abstract artists, was essentially an apolitical organization and did not want to be accused of "sour grapes." Therefore, from the small group that gathered to discuss art, Murphy began to develop the group Art for Oregonians to promote "beautiful and understandable art in Oregon."122

In May of 1959, Murphy (Figure 24) announced that she had conducted an "informal survey of average citizens."123 The survey was actually a petition with "between 3,000 and 4,000" signatures of people who supported the goals of the group. In June Murphy's group formally organized. The Oregon Journal reported that forty to fifty people attended the organizing meeting at the Central Library.124 When the Centennial opened later that month, Art for Oregonians picketed the murals (Figure 25). The publicity surrounding the art at the Centennial continued until September (Figures 26 - 29) when the exposition ended and the daily papers declined to print further letters regarding the event. In the swirl of controversy orchestrated by Mrs. Murphy, it went unreported that Louis Bunce had won a prize at the Centennial's art show. Bunce submitted

122 Ibid.

123 Ibid.

${ }^{124}$ Oregon Joumal, "Art for Oregonians select slogan", (June. 7, 1959), p. 8B, c. 1. 
Figure 24: Oregonian photo of the Mrs C. G. Murphey. Oregonian, July 7, 1958, "New Art Group Gains Popularity".

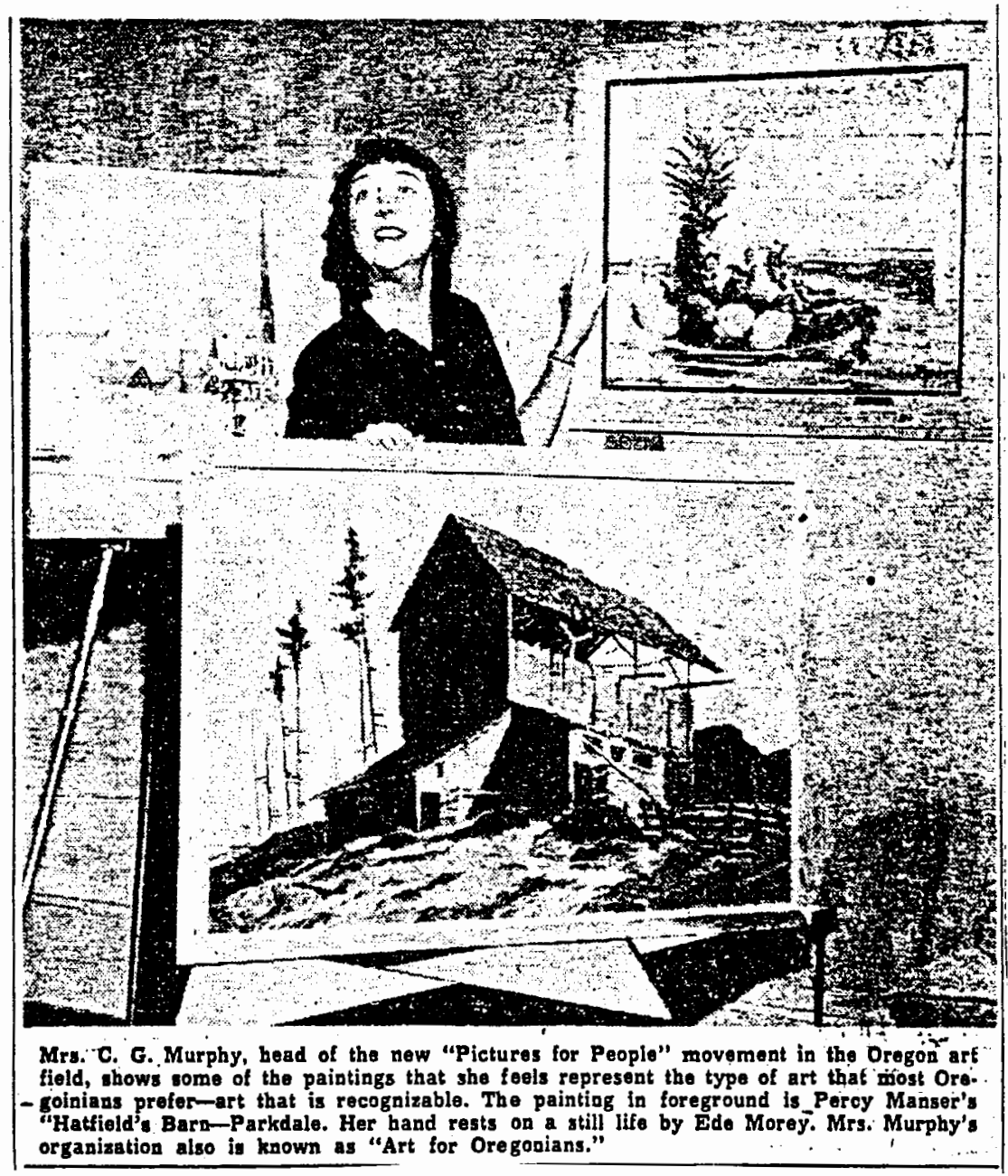


Figure 25: Oregon Journal or Oregonian photo of an Art for Oregonians protester - circa 1959.

Scrapbook of Mrs C. G. Murphy.

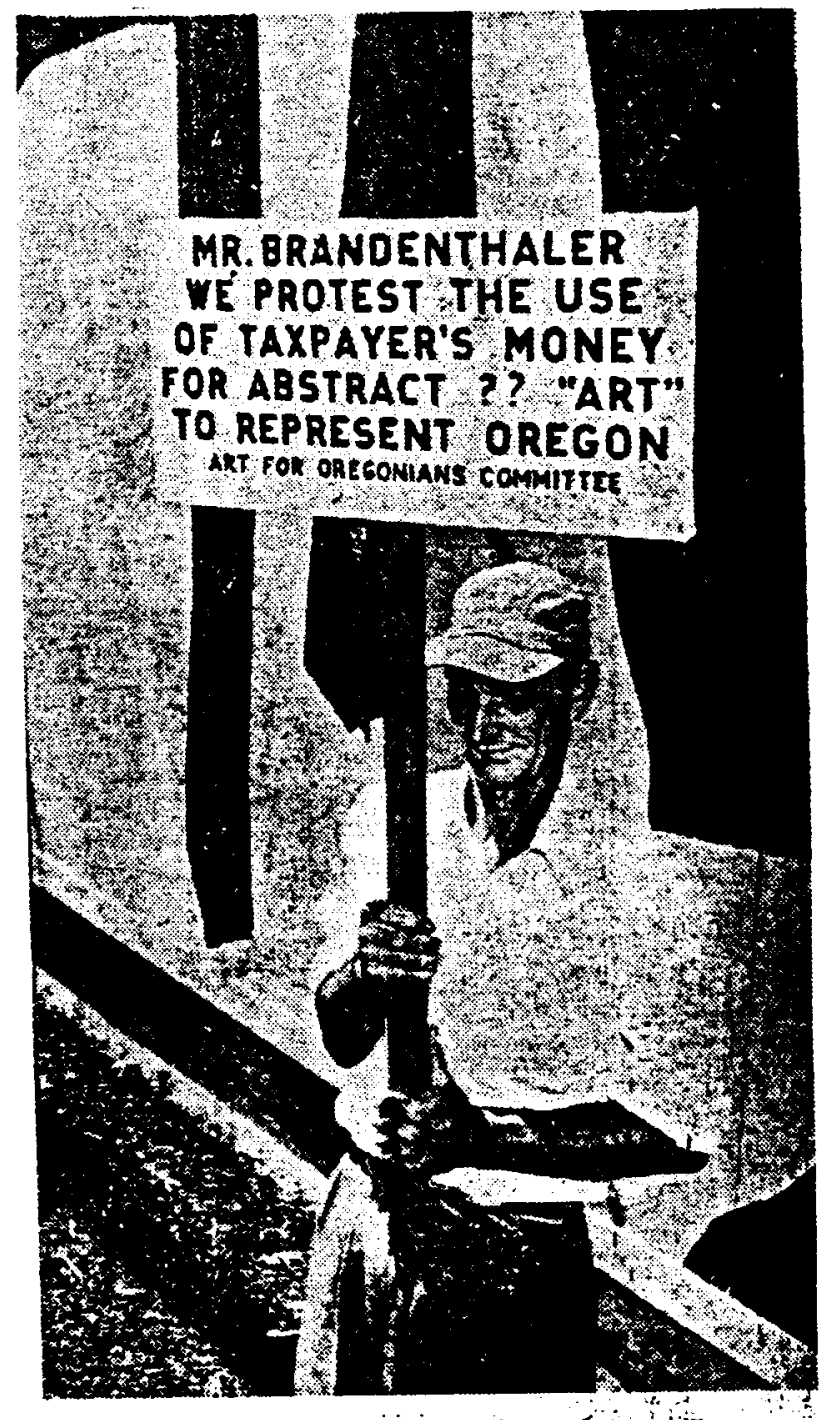

John Vaughan (above) carried this don then of censennial murals Iriday, protesting use of public monos an ibstrect axt Vauphes was hired for the picket patrol by sow group ealliog itsolf Ant for Orogonians. Ithls new. rzanisation will meot Mondas alfhe at Central Library... 
Figure 26: Page from the Scrapbook of Mrs. C. G. Murphy. Scrapbook of Mrs C. G. Murphy.

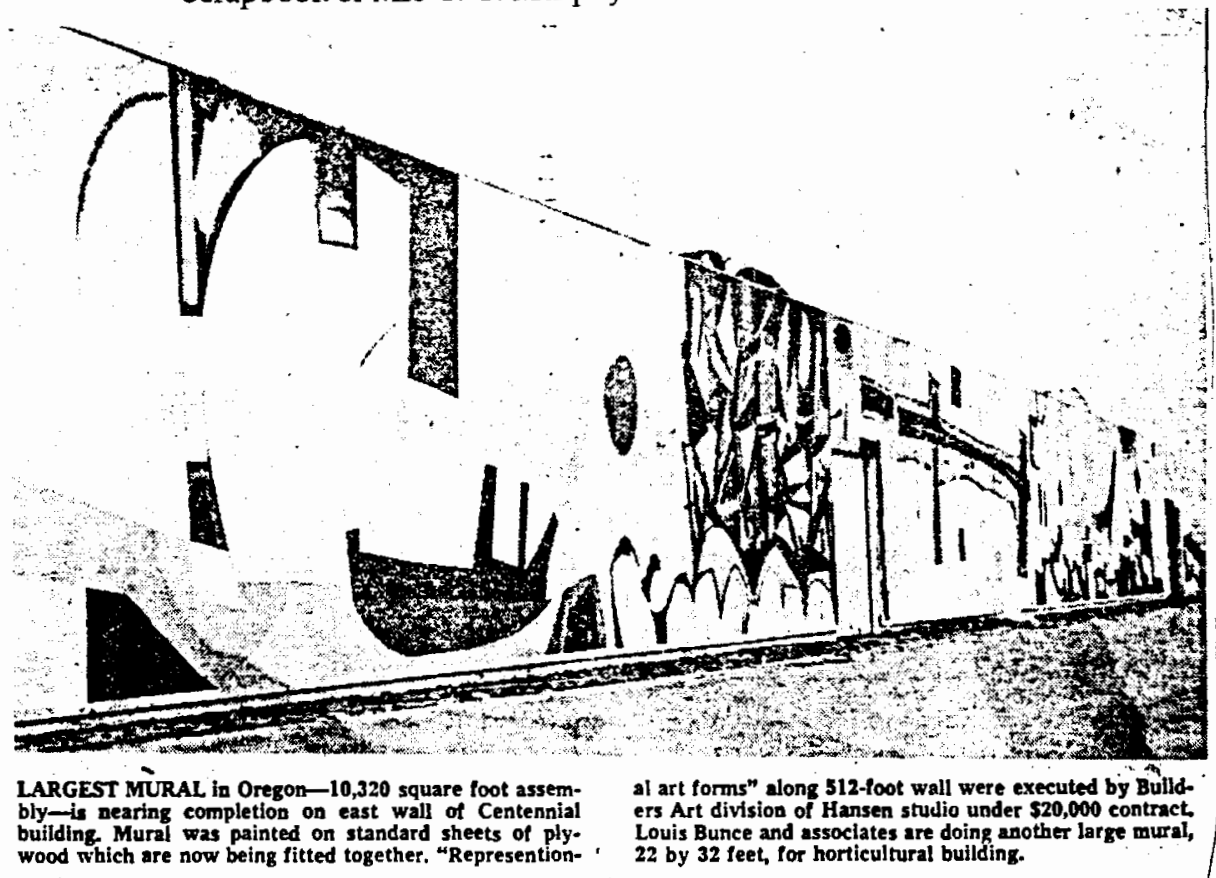

\section{Vancouver Store Littered After Roof Fall-}

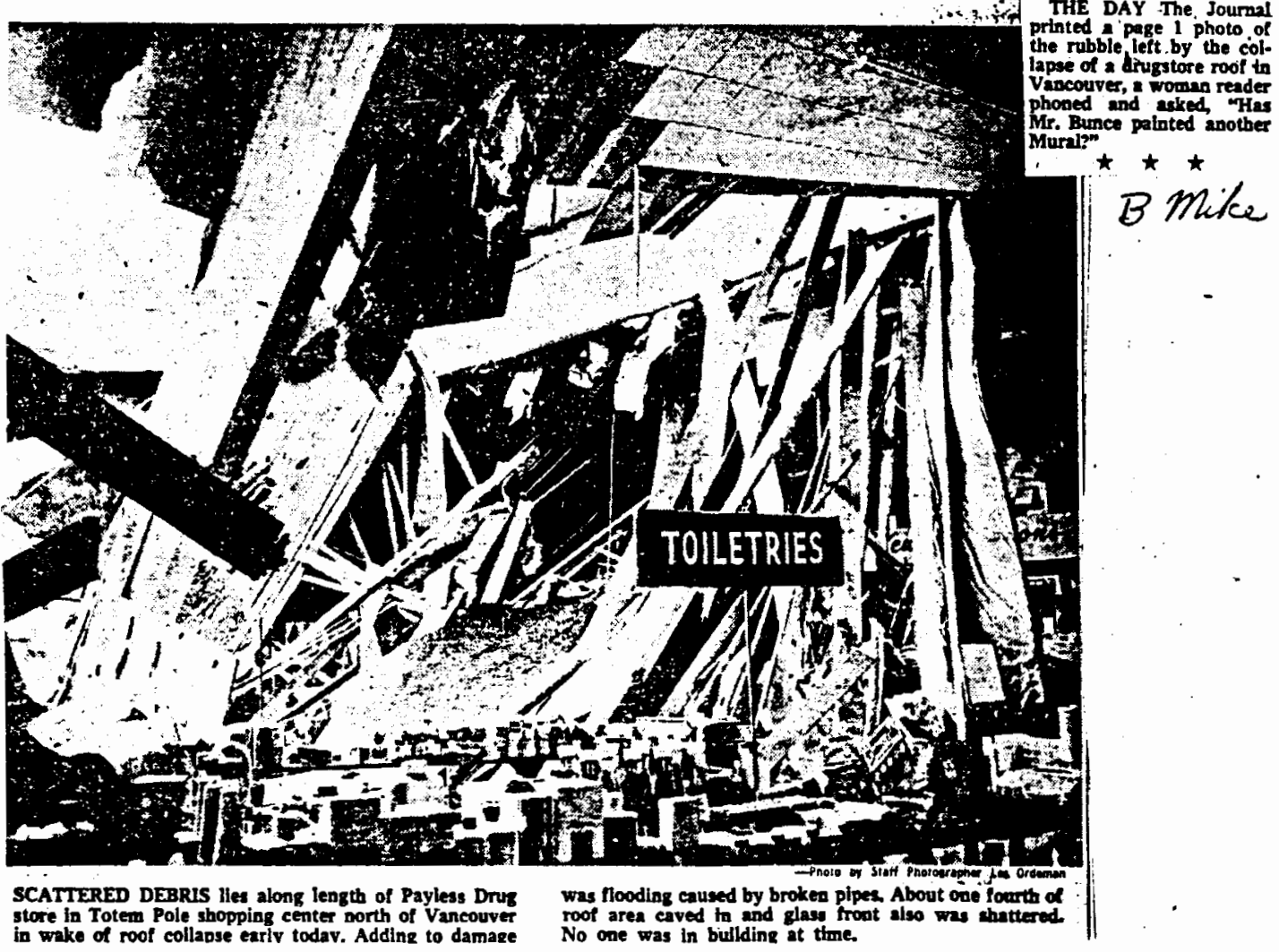


Figure 27: Page from the Scrapbook of Mrs. C. G. Murphy. Scrapbook of Mrs C. G. Murphy.

\section{$\pi \quad \pi$}

MOYÉS-You're a doll for letting a little much-needed light into some of the dark cor. ners of the Portland art dicLatorship with yout Friday col. unn.

What can you expect when the Orezon Centennial commission surrenders its independent judgment to the pince nez set which subsidizes the Portland Art museum and a stable of modern and abstract artists who front for the outfit?

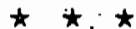

BUT that's not the important point! The Centennial commission is paid by Oregon taxpayers, is spending taxpayers' money, and should give at least a little consideration to the taxpayers' preferences.

I challenge the commission to conduct any kind of honest poll of representative taxpayers that vill show even 5 or 10 percent of them pre. fer modern or abstract art to realistic art $t+$

Gov. HATFIEL would do great credit to his offlce If instead of belore conctrned that all the World's religjons are represented in the 510,000 abstract mural of the history of religion, he were more concerned with the kind of 'art be's getting and if it represents what John Q. Publie wants for the Centennial?

WHOSE - SKIRTS is the Centennial commission hiding behind in turning down a magnificent mural by portland's Ed Quigley, whose work is considered on a par with that of the great Charles Russell and Frederick Remington, lor modern and abstract murals not even remotely related to Oregon's history?

Apparently, according to the papers, the Centennial commission is all set to approve a \$25.000 contract for 500 feet of murals to a sculptor from Vancouver, Wash who expects to use Portland Art museum artists and art students to paint some abstrnct covered wagons and three-legged horses.

Maybe we need a legisla-

tive invesipation. - JAMES

I.WARDWELL, Orenon City. $\times$ a

See where they're ofiering a prize for an Orczon Centennial poem. Toyed with the idea of doing something on the order of "Jlaryland, My Mlaryland" 一nly making is "OREgon JIy OREgon;" of course. But I rtalized how wirong that would be when I sarr some of the "Oregon seenes" to be displayed in the art exhibit and learned that the Civic theater has ehosen "Xo Time for Sergeants" as their Centennial pla:. Any recognizable reference to Oregon is probably taboo.

$$
\star \star \star \star
$$

INSTEAD of the Öregon Trail, I think I'll call it the Burma road and instead of pioneers, I'll teature so me redcosted mounties. Come to think of it, that's getting too close to heme.

I'll make them Bengal lancers. and write it a bit in the styie of T.S. Eliout 'so only Mr. Bunce and the art commission will understand it. I figure I"m a cinch to winSCENTENNLAL SUE (LiR2) $7 / 29 / 54$

MOYES-In that

Friday eivil detenso recent see where the tirst bomb was $4 P$ pos ed was dropped on the alrport Don't they know that our worst enemles wouldn't wart to rid us. of that mural?

Mlaybe one of the CD su. thorities looked it it and thought it had already sutfered a direct hit?-OTTO GOGH, Oswego. (iswe)

THERE'S a new $\star$ mural in Portland, and Louis Bunce's days as a mural expert are now numbered. IIt's at $\mathrm{St}$ Vincent hospital and it wins created by the hospital's crew of painters, men of sheer genius. $\because \cdots$

Originally it started out as a long sheet of plywood on which the crew cleaned their brushes and tried out their colors. After a while it looked so much better than a Bunce. that the painters had it tramed and tacked up as a mural Its title: "Dawn in the SCENTENNLAL SUE (Wi2R) $7 / 24 / 5 y$

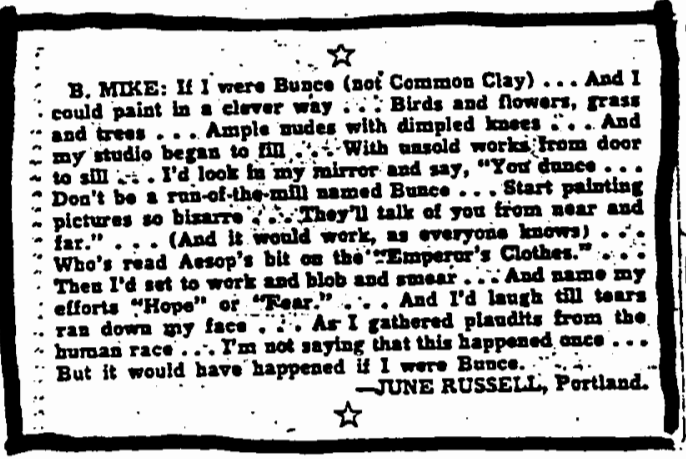

BII MOYES-I êtting con tracts to do certain "murals" locally leads me to believe that some people will fall for. I mean approve, almost anything. So if in the future the eity wants any murals painted Im hereby submitting my Qualifications.

$1 \mathrm{um}$ known from coast to const and from Canada to Merico. (got a friend at each place) I also guarantee the Pollowing:

1 The maral will have color.

2 I will be the oniy one who will know which is top or bottom

3 It! will have no top or bottom

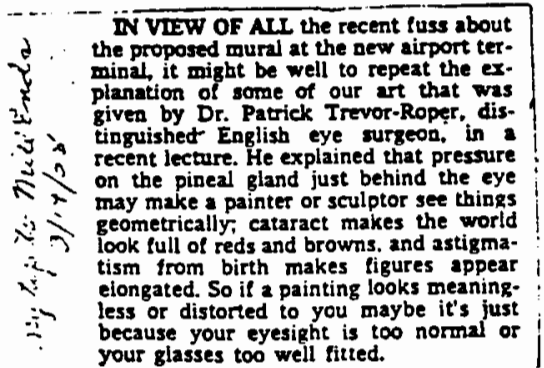
5 Four colors slapped on with one stroke (secret méth. od)

6 will cost four times more (naturilly).

7 Will use first grade students from uny $\mathrm{gram}$ m a school.

$8 \mathrm{Am}$ also a good shoe polisher. A ARTIST.

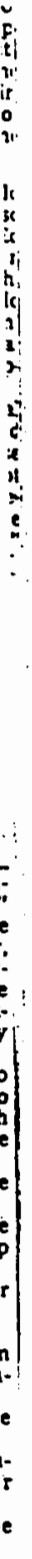


Figure 28: Page from the Scrapbook of Mrs. C. G. Murphy. Scrapbook of Mrs C. G. Murphy.

\section{Who's Un-American Now?}

Congressional criticisms of the American art exhibit in Moscow are twofold: (1) That many of the artists represented have been identified as members of Communist front organizations or are for other reasons suspected of Communist sympathies and (2) that the works themselves are dominated by abstractions and therefore not worthy of display. The strong implication is that there is a connection between the two, that a good red-blooded American likes his art to portray things as they are and that there is something subversive if not downright pro-Communist in works that are not representative.

One turns with some surprise, therefore, to a set of reproductions of paintings on display at the Soviet exhibit In New York. Lo, every single one is strictly objective, virtually photographic in the portrayal of the subject. Some of it is very good, but it is all very conventional.

This is the direct resuit of a conformity forced by Communist authoritarianism. Hitler, it will be remembered, brought about the same thing in prewar Germany: 'he was as outspoken against abstraction as is Rep. Walter of Pennsylvania. The critical U.S. congressmen do not appear to realize that their argu. ments, if carried to the logical end, would lead to a simllar bureaucratic im. position of standards in American art, a following of the Communist Party line.

If the U.S. butists represented in Mos: cow were true party-liners, their works - woifid be natioralistic and academic as aré the Soviet worlis on display in New York But such subversive-activity woild have escaped the congressional investigators. No one would think of calling a painting of a pretty-laced milkmald un-American. poor mixture

Ideology and art make a poor holding no good for the latter.

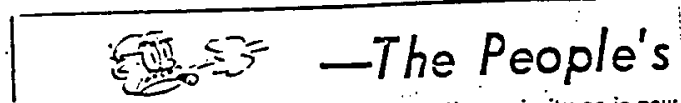

Europeans Lauglied

To the Editor: In your editorial of July 22 entitled "Who's un-American Now?" you point out that the Russian art now on display is very art now on you cite this as proof it is merely coincidence proof it is merely coincidence painters have Communist affiliations. It should be apparent to you that while the Rus. ent to you that while the kus sians are taking the lead in work, their. agents in this country are at the same time busy undermining our art with busy undermining our art with monstrosities and making us the world. And we play right into their hands when we exhibit their work. :"

The extent to which they have succeeded was demon: strated at the Brussels World Fair when crowds stood adFair when crowds stood admiringly before the Russian our poor showing And in writ. ing about the most recent of ing about the Amean exhibits abroad, the American exhibits abroad, that the abstractions were acclaimed and discussed with delight an anther manifestation of the barbarism and crudity of the barbarism and crudity that many Europeans identify they looked upon us as "noble savages" and had the consavages" and had the confused impression that our picEarp and $\mathrm{Al}$ Capone." Is this the way we want to be represeated to the world?

reseated to the world? say that our congressmen are trying to impose bureaucratic standards because they want to see us represented with art which is pleasing to the average citizen, the man you refer to as the "pood, red-blooded American." Bureaucratic presAmerican." Bureaucratic pres-
sure is required when a minority group imposes its de- ires on the majority as is now being done. None is - needed when the "good: ried-blooded American" himself is making the selection. " $\quad \therefore=$

You inter that since the Rus. sians have managed to turn sians havtiful, representational art under a totalitarian gov. art under a cotalitarefor if we ernment, that the of work it will mean that we have to talitarian government: Ihis is tal like saying that dog is an animal and cat is an is an anind this proves that a animal and this proves

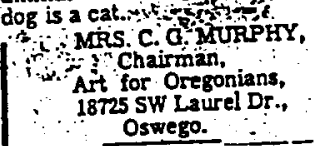

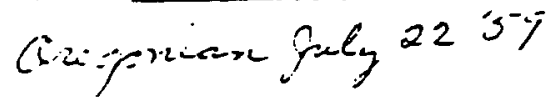


Figure 29: Page from the Scrapbook of Mrs. C. G. Murphy. Scrapbook of Mrs C. G. Murphy.

Murals Defended

To the Editor. In answer to

letters that have appeared in The People Speak through the summer. let me say it is fortunate that people in Oregon are becoming ware of the good contemporary art that is going out from the $m$.

directiy to the public. is Antagonism to what is new is a familiar reaction. In the past people ridiculed and rejected the truly vita no one their time. Today no one "Mother" or Van Gogh's "Mother" of Van Gogh's "Sunflowers," yet similar mis. informed and unsympathetic criticism was directed against these masterpieces as that used by Mrs. Murphy and her "Citizens for Art" in discussing the

THE KIND of painting which such people advocate which such people advocate as an altemative to the aruse

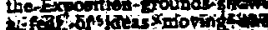

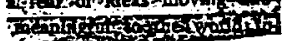
deferes because of the sep ration of church and state. and Jogically because of the need to represent 176 differen churches, universal abstrect. symbols had to be substituted for traditional religious forms. That we now have such a monument of great faith and great art is a tribute not only to the skill of the artist. Carl Morris. but also to the vision of the Centennial religious committee. No group so sadly lacking in understanding of what art is significant to our age is going to set back the clock!

6825 NE Fremont.

'Backward' Portland - is

To the Editor: In an-attempt to answer Arthur V. Goddard, who describes Portland's highly creative and fertile artists, led by Louis Bunce. is "Irus-" trated maniacs who can't tell beauty from horror." I should like to

In the production notes to his piay "The Glass Menagerie," piny "The Glass Menagerie," writes:

"Everyone should know nowadays the unimportance of the photographic in art: That truth, life, or reaity is an orimarination can represent or suggest, in essence, onily suggest, in essence, oniy through changing into other through changing into other merely present in appearmerely

The reluetance of many in Portland to accept this idea labels us uninformed, back. ward and unwilling to accept "new" concepts.

Also, may susgest that Mr. Goddard and those who agree with him see the Northwess $2 \mathrm{n}$. vitational Centennial show at in example of truly beaui. ful - and meaningful " moder art"? Artists exhibitine from Portland. Seattle. Britts Co lumbia, all over the Northwes: are represented. It is an

\section{Art as Expression \\ To the Editor. Now that the public has been instructed to keep its mouth shut and leave \\ $\therefore-5 F-7$} art to a politicaily appointed committee. it seems tume for us to reexamine this
subject very carefully.

We are being told, in effeck. that art is an esoteric, ob scure thing to be reserved for select few. Though the pub. lic is expected to foot the bill for in sublic buildings) as a mat. ter of fer of fach the groping for beauty and self-expression has been an integral part of man's nature since the first caveman painted a bison on the wall of his home. It is a part of all of us. And a real work of great explanation or apology.

TOURISTS from ail parts of the worid and all waiks of life stand in tribute before the painting of Mount McKinley painting of Mount McKiniey by Sidney Lawrence which hotel in Juneau.

I wonder it it will be possible to convince the people of Oregon that srt is a thing completely divorced from the ture around us. It is beauty that lured most of us to live here in the first place, and so it seems likely that wie have a citizenty that is peculia-ly sensitive to it 1 wonder if we are going to deny the integrity of our own instincts and ac. cept . as "art" distortions which are a negation of all this loveliness. Dell Murphy,

Oswego.

\section{From 'The Fountainhead'} To the Editor: I got quite a harge out of Eric Smith's leter about we intellectual mor. uns "attempting to discredit he reputation of ane arist and irtist? You can enlighten him hat it's morons' tax dollars. f wonder how many abstracts Mr. Smith has hanjing around in his borme for support of this artist.

Mr. Smith contradicts himself if he feels he falls into this "aristocracy of the mind who category. Part of his spiel it practically verbatim from the hero's speech in the courtroom from Ays Rand's novel "The Fountainhead," an excelien work of fiction. The hero wa could ligure out what the devil he was going on abouk. so giess we can acquis Mr.

We absolute zeros do not tir 20 push our stupidity onto the "aristocracy of the minas" as they try to

RICUARD BROWN. 10359 SW Eastridge Ave.
To the Editor: $A$ friend and I went to the Centennial Exposition. We hurried into the Ice Capades and saw a wonderfully beautiful performance. Such superb grace, such beautiful costumes, pretty girls and. the young ment is was well worth more than the price of
tickels, but it finally had to tickels.

We went around emong the exhibits, and they were very interesting, especially th a wood screen of carved teak. the work of three men for nine years. It must have been priceless, the labor of real art thing the could produce somerianity.

Then we walked out to view: the grounds. What a shock af ter the experience inside! The Iirst thing to meet our eye was that enormous splash of paint dauks on the sice of the building. A dozen kids with bucket of paint each could not have done worse. It was worse than the joke at the airport because it was larger. Then the painted iron things in the fountains and around the grounds. I saw some children climbing over one and trying to break a piece off it. I thought to myself. "They could not hurt it or make it worse." We went on to the open air pavilion with the frozen wood pile in the center. Anyone can see the beauty of a great tree; the avmil scraps

The Aeligious Mernorial building-those priceless me imentos of early religious life in Oregon surrounded by ' bunch of hideous blokches and palches-no meaning, no : re spect, nothing!

How 'Jong is Portland going to put up with this bunch of irustrated maniacs who can't tell beauty from horror? They are using our mooey to make? us look ridiculous not only to our visico

What letown atter the eautiful ice Capades! $2310 \mathrm{NE}$ 49th 'Ave.

mission has been the tarket of abuso from hamiess people Their superannuated opinions. Their attempts to discredit the repuration of one artist and those who support him have been too leeble to warrant an

The tactics of this crusarie have changed, however. This innovation came in the form of - question posed by one lelter writer. "Is it a healthy sign." he asks. "that a handful of Self-atyled 'experts' can impose their taste on the majority?" ject briliant new plan is to sub

To what does "the miority" reler? Does the "tord inply numerical superiority? The opin ion of the largest number of rock-and-roll, TV western. bage-satiated creatures actual ly counts? Millions of absolute zeros, whose ultimate function here on earth is to function passogeways for tood. should pass judgment on art?

It is very well possible that this bow-wow theory will one day be put into effect. The inwho ireely aupport the million doll treety aupport the millionin order to share vicariousty their tree jove existence: indirectly pay the wages of the tragh-picicers the wages of the of the picrs who write most shows, thrill-noveis, teievision zines: who provide and magahomes cutomide I vish robes for the lowest and vardof menkind who have leamed only the secret of prolonear dis. torted movements while sing. ing: who sllow men to singover $\$ 100,000$ a year for hittin well be thit yes, it may very which mates idols of those who exploit it, one day may deprive on irtist of a commission.

But it will never be possib] to control the creation of one who can shamelessiy say. "I have a brain." And none of us inpress our will upon him.

There is no such thing as an intellectual democracy. Th 
Figure 30: Oregon Journal or Oregonian photo of the Mrs C. G. Murphy denouncing the State Fair Art Jury, 1960. Scrapbook of Mrs C. G. Murphy.

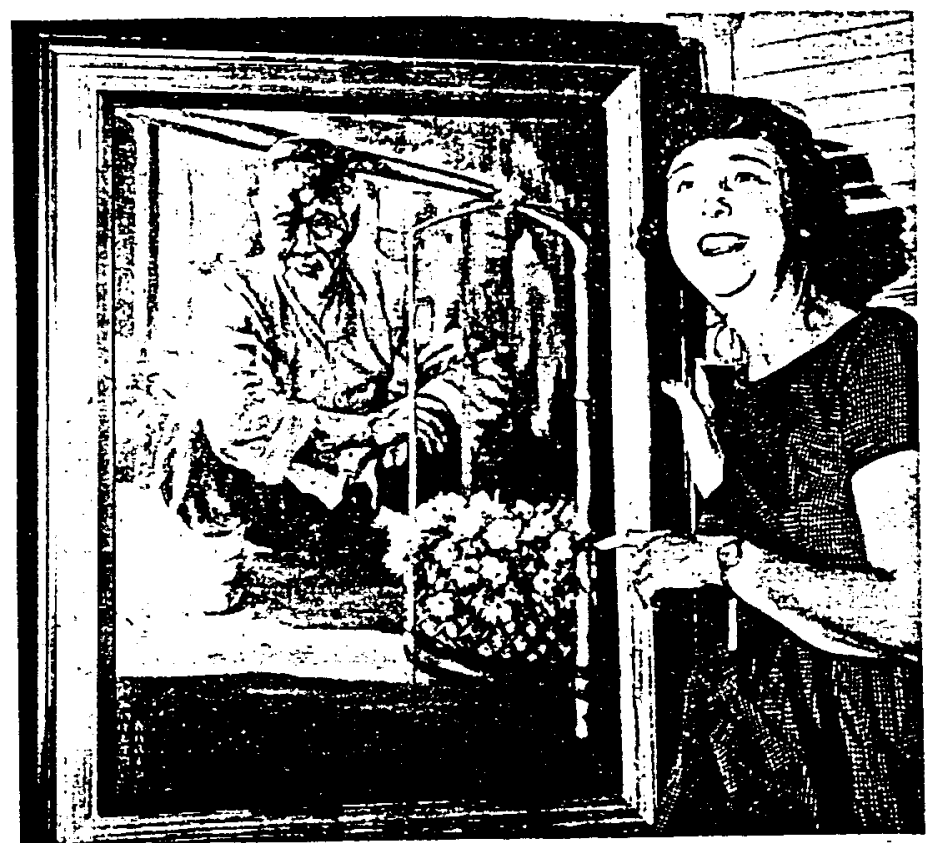

"This is excellent example of traditional art," said Mrs. Chester G. Murphy (right), Citizens for Art chairman, of oil by Hamilton Aaris above, that state fair art jury rejected. Another Aaris painting of Oriental is in fair exhibit at Salem. 
Regions, 1958, (Figure 17), a work that was similar in color and style to his airport mural sketch. In the year after the Centennial, Art for Oregonians changed their name to Concerned Citizens for Art in Oregon. The following year, Murphy's group called into question the jury process used by the Oregon State Fair's Art Show (Figure 30). This controversy eventually led the fair's art director to quit in frustration. Other Concerned Citizens for Art targets were Governors Hatfield and $\mathrm{McC}$ all for allowing the teaching of abstract art in state colleges 125 and the Portland City Council for giving $\$ 10,000$ to the Portland Art Museum.126 Gordon Gilkey, who was Chair of the Art Department, then Dean of the School of Liberal Arts at Oregon State University, recalled that Mrs. Murphy had on several occasions written to him to protest the way art was being taught at Oregon's colleges. One particular exhibition at Oregon State upset Mrs. Murphy. Gilkey recalls,

The Student Union (at OSU) put up a display by some minister's wife. The Oregonian called it "Psycho Art." She (Mrs. Murphy) wrote a nasty letter to me. Psycho Art was really psychological interpretations. She was upset and said that we shouldn't be showing that stuff to kids. I had to write back and say that I didn't have anything to do with it and that the student's union ran that. 127

Gilkey, as a prominent member of the Oregon art community, also served on both the State Fair Art Exhibition jury and on the Centennial

${ }^{125}$ Gilkey, (1996).

126 Oregon Joumal, "\$10,000 budget for museum sparks controversy", (June 27, 1963), p. 2, c. 1.

127Gilkey, (1996). 
Exhibition Art jury where he again encountered Mrs. Murphy. Mrs. Murphy objected strenuously to Gilkey's involvement in these exhibitions because he was a partisan of modern art. She explained in a letter to Gilkey:

We are aware that there are many, especially in the teaching profession, who have been forced by economic necessity or bureaucratic pressure to try to embrace both schools of painting ("modern" and "traditional"); and while we may sympathize with what must be an uncomfortable position astride two such conflicting ideologies, the fact remains that our traditional painters don't want that type of judge. They feel that these two means of expression are based upon concepts which are diametrically opposed, and that no person can do justice to both. One cannot love beauty and exalt ugliness. -- And surely the keynote of the so-called "modernistic" school of painting is ugliness! 128

In other letters to Gilkey, Mrs. Murphy asserted that she represented not only "concerned citizens" in Portland, but also groups in Tillamook, Sandy, Corvallis, and a group in "Southern Oregon."129 Murphy also sent Gilkey a "educational publication."130 The booklet was titled Our Future as Revealed by "Modern" Art and was written by Joan Bellaire. The preface of the booklet explains how Joan Bellaire had studied modern art but how "the emptiness of this form of expression had driven her from its

${ }^{128}$ Murphy, Mrs. C. G., Letter to Gordon Gilkey, (May 12, 1960).

${ }^{129}$ Murphy, Mrs. C. G., Letter to Gordon Gilkey, (June 21, 1960).

${ }^{130}$ Murphy, Mrs. C. G., Letter to Gordon Gilkey, (June 7, 1960). 
ranks." 131 The booklet describes how the art world had been taken over by "modernism" which was a part of a communistic, humanistic, and atheistic plot. The displacing of "beautiful" art standards with those of modernism was just the first step towards anarchy and communism. ${ }^{132}$ In their correspondence Gilkey asked Mrs. Murphy whether the name Joan Bellaire was a pseudonym. ${ }^{133}$ Mrs. Murphy replied that it probably was a pen-name but that "Under the circumstance she might be wary of communist agents."134

In the late sixties when Governor Tom McCall purposed and created an Oregon Arts Commission, Gilkey again encountered Mrs. Murphy. Gilkey recalled that:

We got the Oregon Arts Commission appointed and were defending it before the legislature. She came before it and passed before the committee photographs of nudes in the Museum, saying this was the type of art that the public was paying for at the Portland Art Museum. We had to remind her that the Museum was a private organization. And the minute we got all of it passed what started was pathos. Tom McCall told us to continue and we wrote a state of the arts book at that time and published it. Then who should on Tom McCall's doorstep appear but Mrs. Chester Murphy. She said she had a candidate for director of the

${ }^{131}$ Bellaire, Joan, Our Future as Revealled by "Modem" Art, (Fullerton, Cal.: Educational news Service, 1960), preface.

132 Bellaire, p. 6.

${ }^{133}$ Gilkey, Gordon., Letters to Mrs. Chester G. Murphy, (May 16, 1960).

${ }^{134}$ Murphy, Mrs. C. G., Letter to Gordon Gilkey, (June 7, 1960). 
commission: HER HUSBAND. (Big laugh) Tom just sort of ushered her out. 135

Gilkey noted that he didn't take her very seriously and said that "I didn't pay much attention to them until they started fussing with me," but as a public official felt that he had to respond to her so that "she wouldn't have an excuse."136When asked whether the organization Concerned Citizens for Art in Oregon was a one-woman crusade Gilkey responded:

No, she went around organizing in different communities

- Citizens for Art - and the little old ladies signed up. They had units in Eugene, Salem, The Dalles, I don't know where else. 137

The group remained active until the late 1960s. The Oregonian and the Oregon Journal both reported in 1964 that Concerned Citizens for Art had reelected Mrs. Murphy as president. ${ }^{138}$ Mrs. Murphy's own scrapbooks show that the group continued to write letters and oppose modern art until 1968. The last target of the group was a large metal sculpture by Bruce West installed in the lobby of the renovated Civic Auditorium. But compared to the protest surrounding the airport mural and the centennial the stir was minor. Doug Baker in his Oregon Journal column noted that there was little controversy and noted that "Mrs. C. G. Murphy has ceased to tilt at

${ }^{135}$ Gilkey, (1996).

${ }^{136}$ Ibid.

${ }^{137}$ Ibid.

138 Oregonian, "Group re-elects Mrs. Murphy", (Nov. 9,1964) sec. 2, p. 3, c. 6, \& Oregon Journal, "Officers named by art group, Mrs. C. G. Murphy", (Dec. 12, 1964), p. 2, c. 8. 
windmill abstractions." 139 Three days later Baker noted that "Mrs. Murphy, arch foe of the non-representational painters, is still wielding her lance" and printed a letter by Mrs. Murphy:

Dear Doug: Give me a windmill like the proposed $\$ 200,000$ in tax funds for the governor's politically-appointed art commission, and I'll start tilting. We are told that there isn't enough money to care adequately for unwanted or disturbed children, but they contemplate giving our money to the same individuals who defaced the Centennial grounds and more recently, the new auditorium. 140

${ }^{139}$ Baker, Doug, Oregon Journal, "Bakers Dozen: Nickel-Nursing Portland Deserves Third Rate Art?", (May, 27, 1968), p. D2.

${ }^{140}$ Baker, Doug, Oregon Journal, "Bakers Dozen", (June 1, 1968), p. D2. 


\section{Bunce's Later Work}

Bunce's work in the early 1960s shows that he was incorporating more de Kooning-like expression into his works. Big green, 1960, (Figure 31 ) is one of a series of works that are predominately green and blue with small amounts of yellow. The brush strokes of these pieces are much bolder and much less contained than his work prior to 1959.

The figure returned to Bunce's work in the Table of Lovers, 1963, (Figure 32). Part of a series of still-lifes, the painting can either be read as a abstract still life or as a reclining nude. Bunce said that both associations were equally valid.141 This painting, and many of Bunce's later works, subtly mock the conventions of art. In the late 1960s, Bunce was obviously influenced by the revival of Magritte. In Page of Skies , 1967, (Figure 33) five realistic paintings of clouds have been applied to a larger white canvas that serves as a frame. Apple, 1968, (Figure 34) is part of a series of fruit, tomatoes and roses. These realistic paintings enlarge the subjects of traditional still life to gigantic proportions. The traditional still life table is represented in these paintings by Bunce's application of the " $\mathrm{L}$ " shaped piece of metal (a builder's square) to the canvas.

Bunce retired from the Museum Art School in 1972. In retirement he continued to paint in his Portland studio and continued to show at Arlene Schnitzer's Fountain Gallery. 
Figure 31: Bunce, Louis, Big Green, 1960.

R2 plate 5, Rachel. Louis Bunce, A Retrospective, exh. cat., (Portland Art Museum, 1979), p.

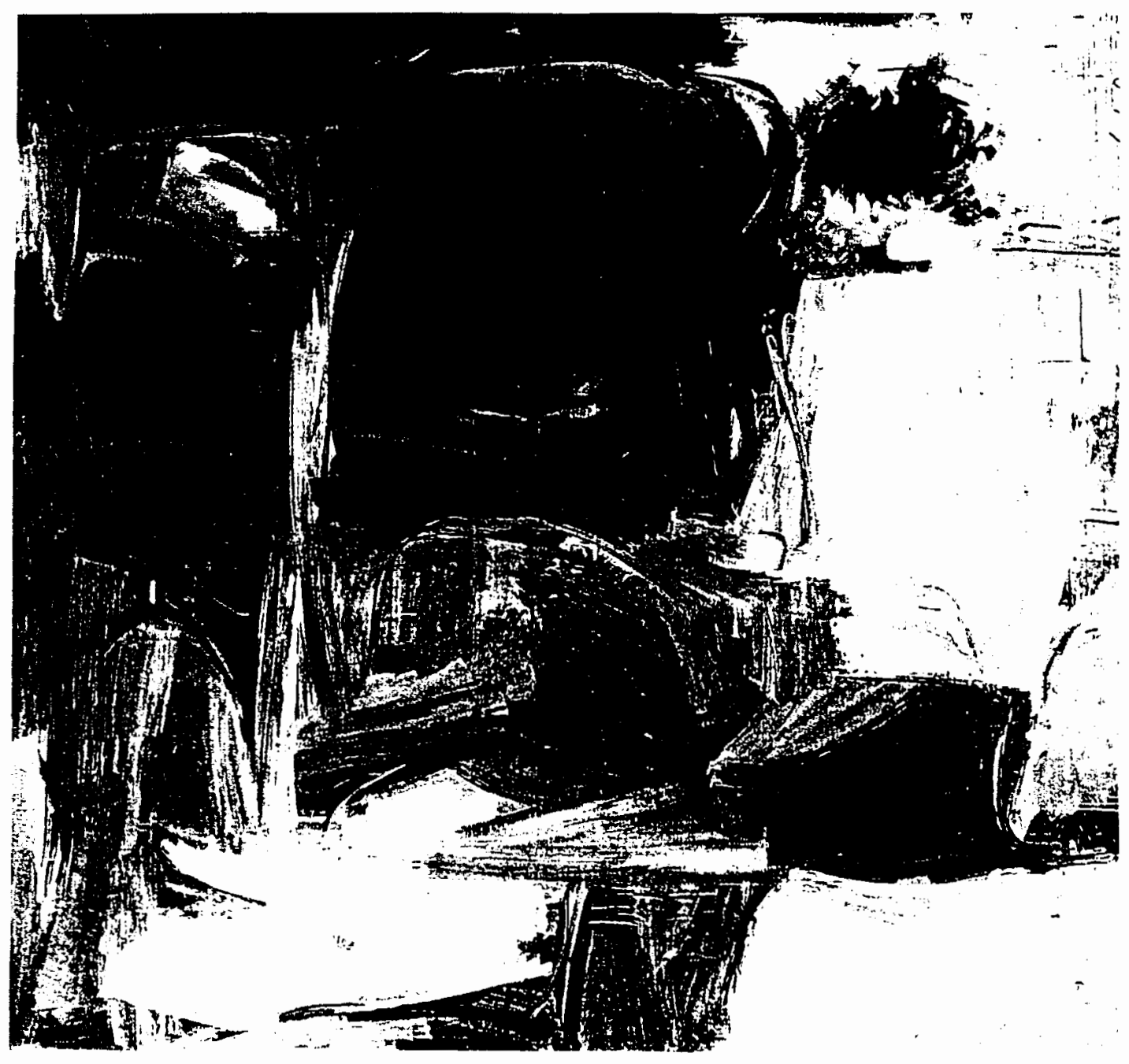


Figure 32: Bunce, Louis, Table of Lovers, 1963.

Rosenfield, Rachel. Louis Bunce, A Retrospective, exh. cat., (Portland Art Museum, 1979), p. 33 , plate 6 .

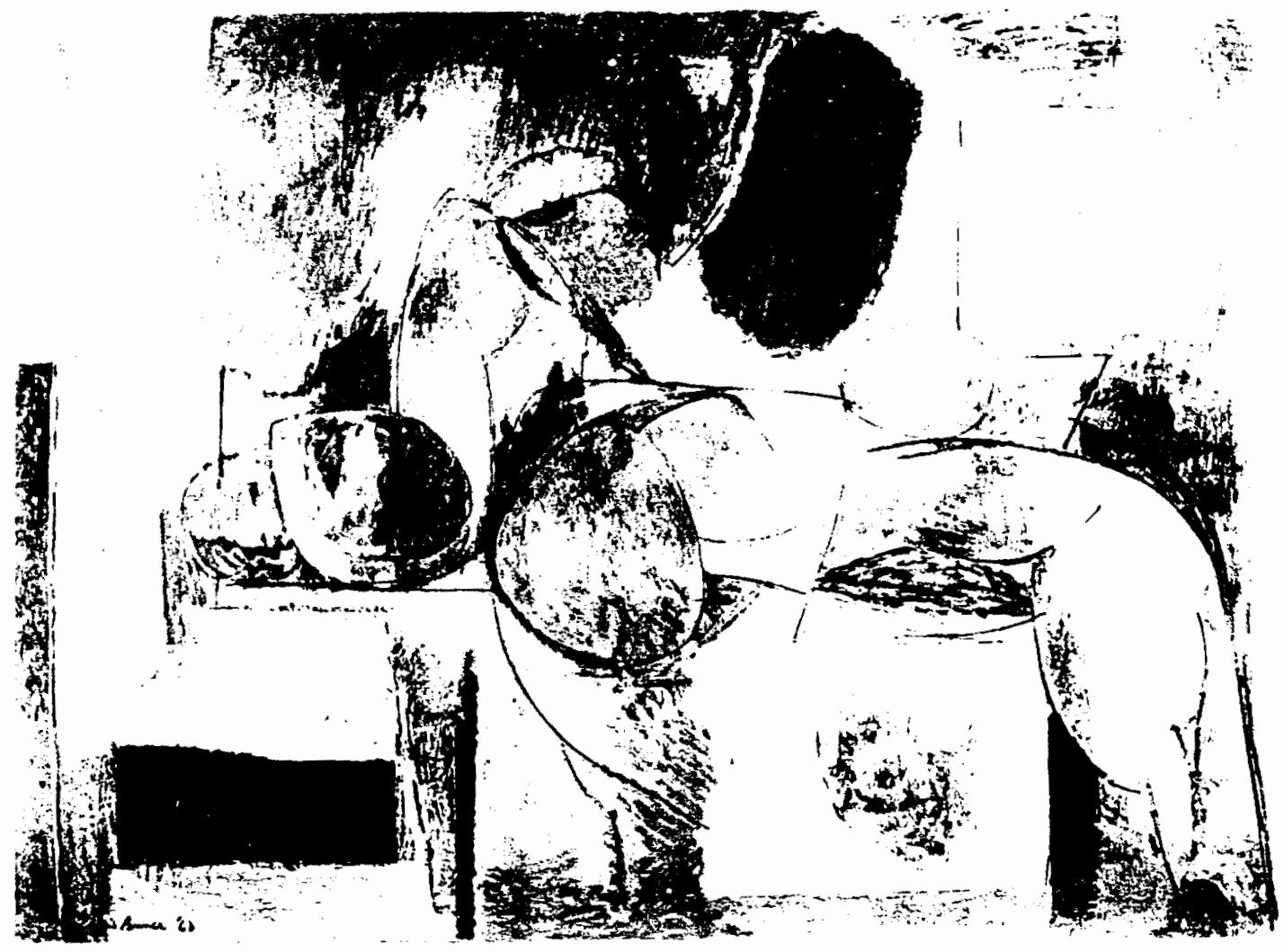


Figure 33: Bunce, Louis, Page of Skies, 1967.

Rosenfield, Rachel. Louis Bunce, A Retrospective, exh. cat., (Portland Art Museum, 1979), P. 43 , fig. 17.
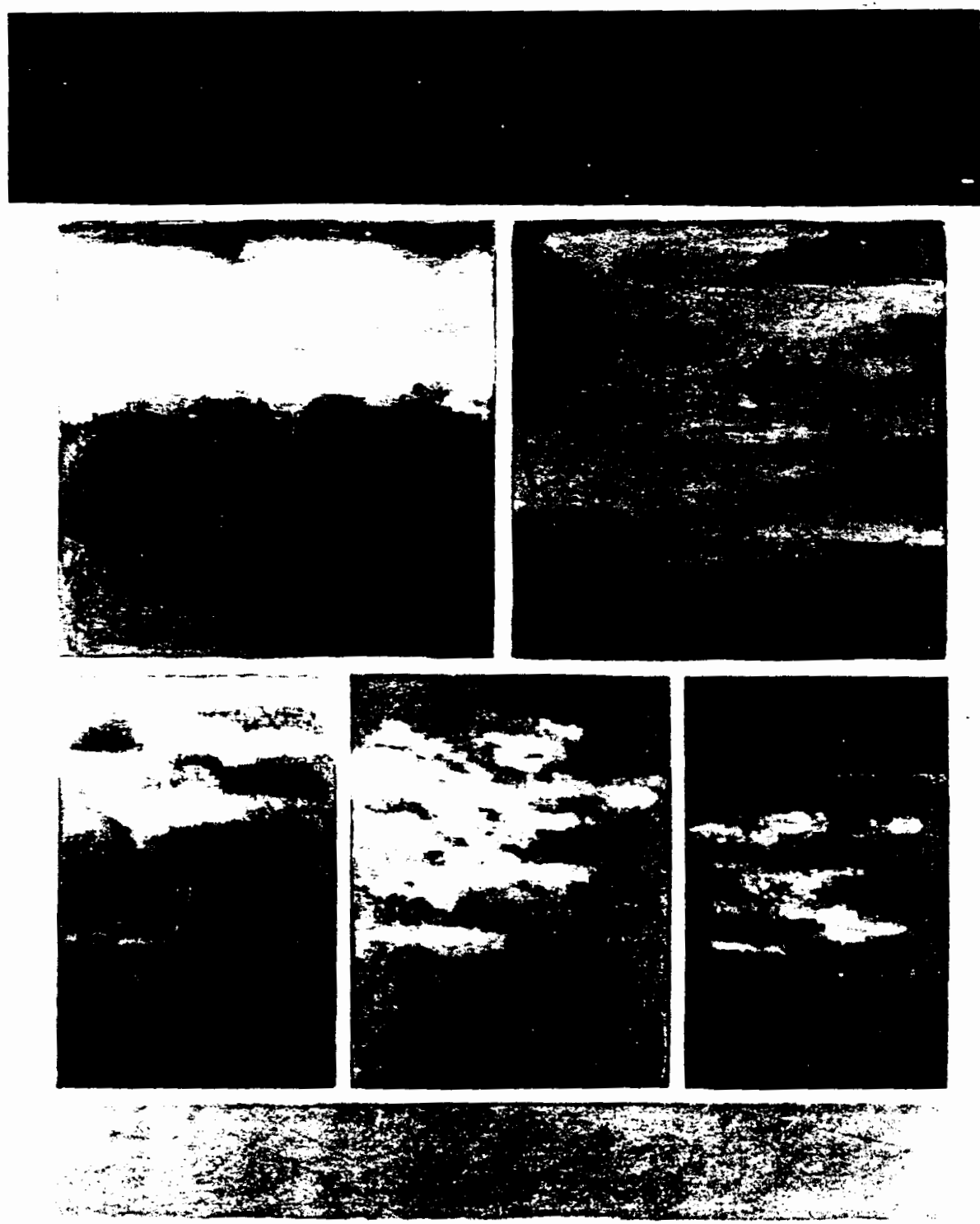
Figure 34: Bunce, Louis, Apple, 1968.

Rosenfield, Rachel. Louis Bunce, A Retrospective., exh. cat. (Portland Art Museum, 1979), p. 44 , plate 9 .

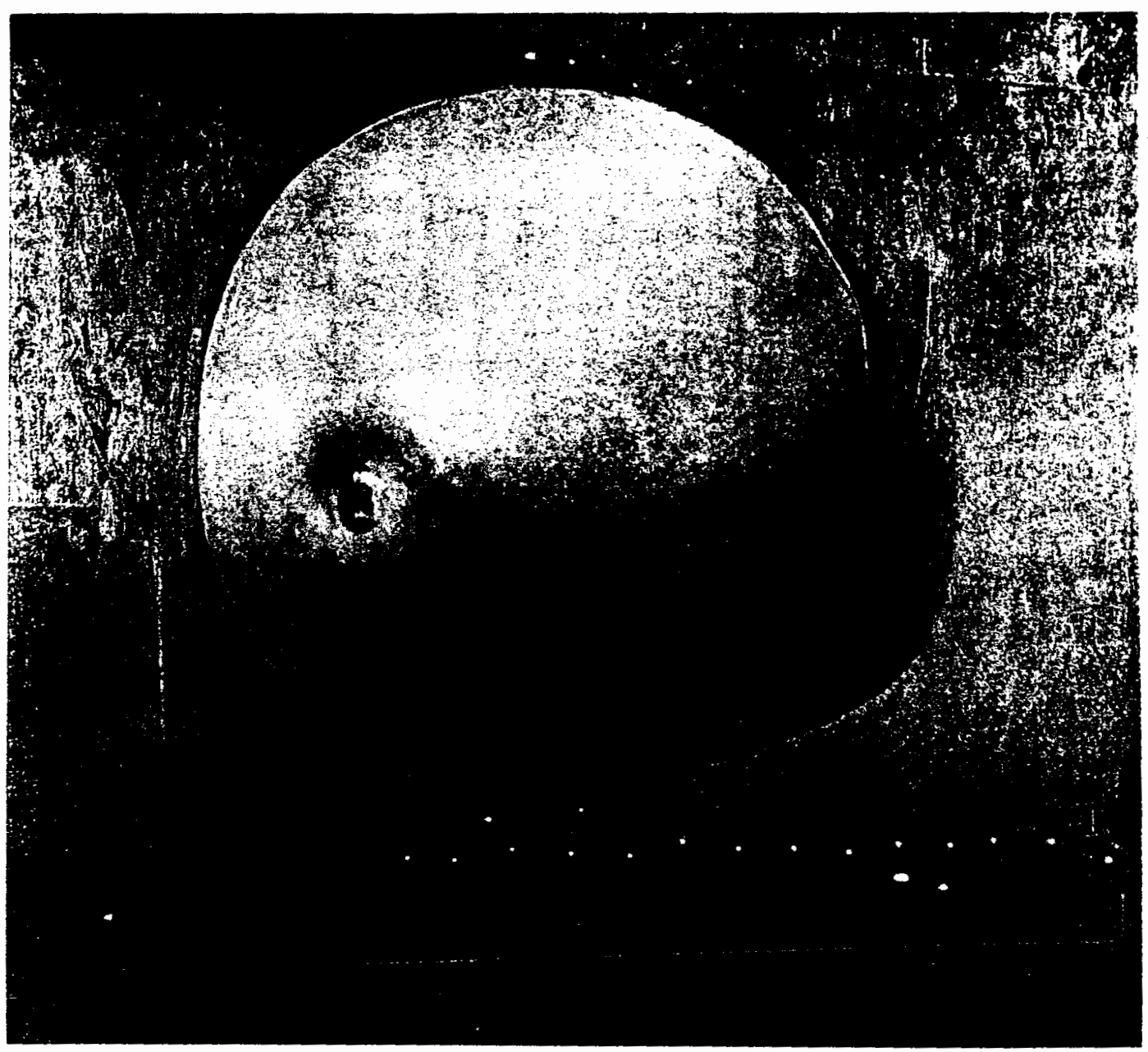


Bunce's late works show a dramatic simplification of line and a reduction to simplified forms. In Harborside II, 1978, (Figure 35) he again toyed with the juxtaposition of two art conventions: the nude and the landscape. The composition of the work recalls his 1934 work Beach, Port Orford (Figure 5). The lighter portions of the work are a sandy pink while the dark portion is dark blue-green. The work can either be seen as a harbor among sand dunes, or as a nude with her legs spread. In Bunce's last paintings, large vertical geological formations appear in his simplified landscape. These can be seen in the large unidentified painting behind Bunce in the photo from 1979 (Figure 4) and in Sea Sentinels, 1982, (Figure 36). In the painting in the photo and in other many works from this period the "sentinels" emerge from the sea like Haystack Rock and other Oregon coast landmarks. In Sea Sentinels the formations have freed themselves from the sea and appear to be floating up and out a window-frame view.

From the airport controversy until his death, Bunce was a prominent fixture in the Portland art scene, thriving on the media attention derived from being "the airport muralist." In 1961, two Portland television stations aired feature programs about Bunce. KPTV's "The Jazz Arts" featured Bunce painting while a jazz band played in the background. The Oregon Journal columnist Doug Baker reported about one occasion when he witnessed Bunce being interviewed by a local TV station. The interviewer asked Bunce if he painted nudes. Bunce responded "Yeah, but I really like to paint feet. You know feet reveal a person's entire character -- 
you can analyze a person by his toes." Bunce told Baker later "I think the guy thought I was serious." 142

When Bunce died of cancer in 1983 his memorial attracted three hundred people. He was eulogized by his former student Arlene Schnitzer and by other members of the art community. The Oregonian obituary pointed out the profound influence Bunce had on art in the Northwest: as gallery owner, as an art teacher, and as an artist. The paper neglected to mention the late 1950s controversies and Bunce's role in making Oregon "art conscious."

142Baker, Doug, Oregon Journal, "Baker's Dozen: Oregon's Gully Jimson", (Sept. 7, 1977), p. D6. 
Figure 35: Bunce, Louis, Harbor II, 1978. Schnitzer, Arlene. Fountain Gallery of Art, 25th Aniversery Exhibition, exh. cat., (Fountain
Gallery, Portland, 1984), p. 19.

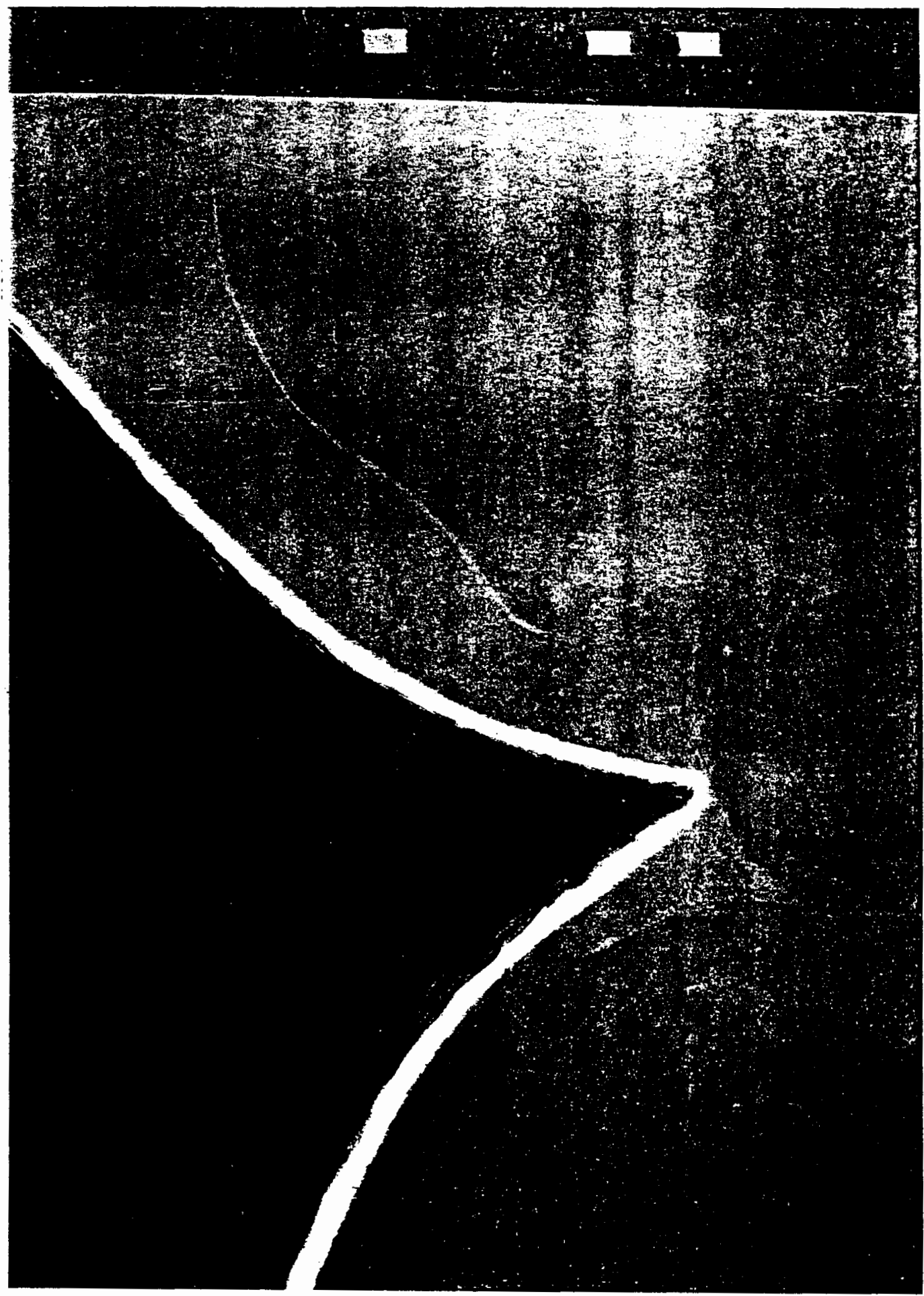


Figure 36: Bunce, Louis, Sea Sentinels, 1982.

Guenther, Bruce. 50 Northwest Artists, ( Chronical Books, San Francisco, 1983), p. 27.
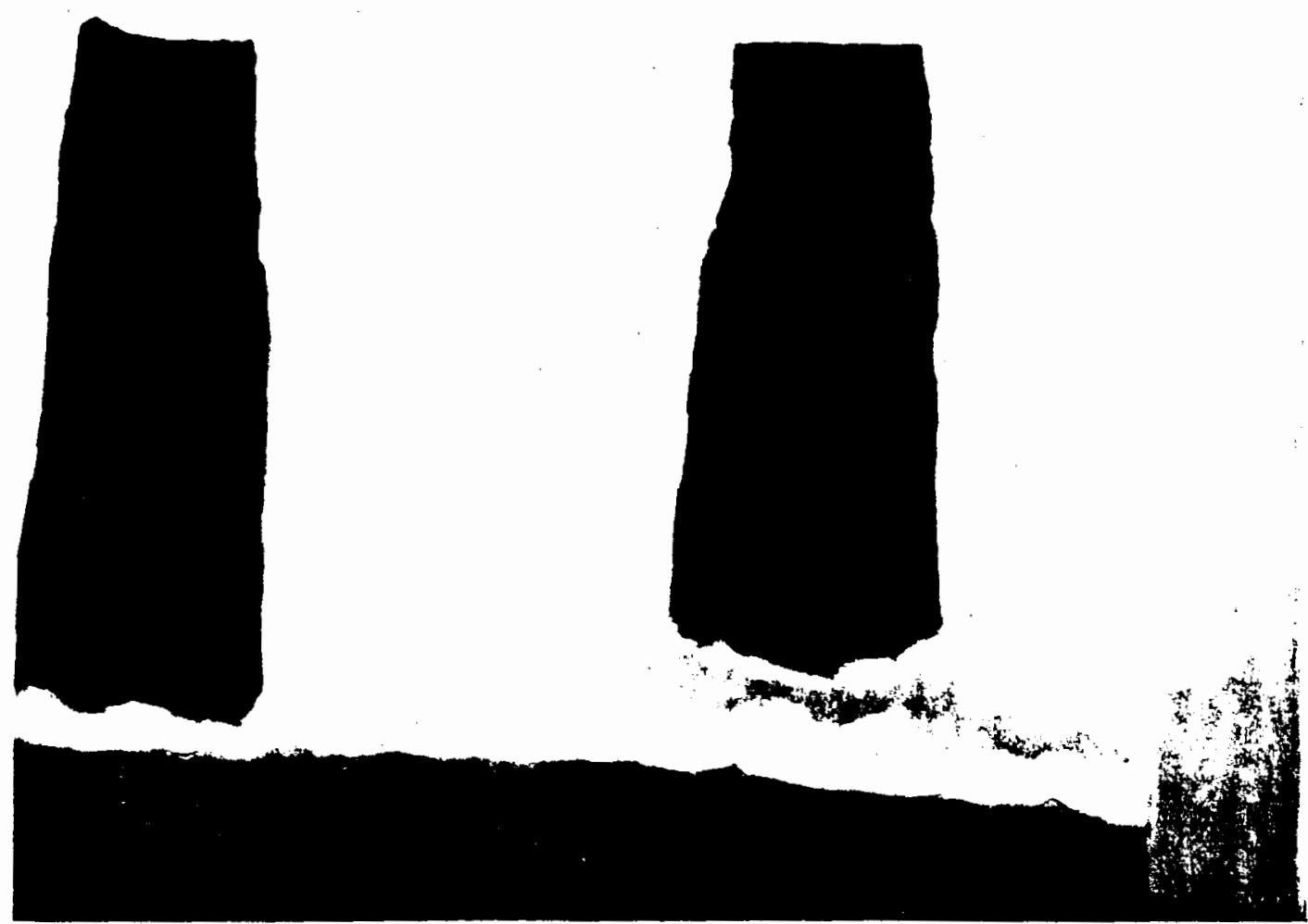


\section{Art and Patronage in Portland since the Controversies}

The Portland Art Museum and its school, now the Pacific Northwest College of Art, still remain the most prominent art institutions in Portland. However the Museum no longer is the only durable art institute in Portland. Since the fifties the Portland State University Art Department has expanded and now has almost as many instructors as the Museum's school.143 In addition the Oregon School of Arts and Crafts institute, Lewis and Clark College, Marylhurst, and the numerous community colleges have also expanded their student enrollment and fine art faculties. The Museum continues to mount a Oregon Biennial exhibition but seldom mounts shows of individual local artists. Most local artists show in the numerous private galleries which have proliferated in the last thirty years.

A few years after the Centennial Exhibition, two galleries opened to provide commercial outlets for Portland's modern artists. The first gallery was the Image Gallery operated by Jack and Barbara McLarty which opened in 1961. Arlene Schnitzer's Fountain Gallery opened three months after the Image.144 Arlene Schnitzer is the wife of Harold Schnitzer, a prominent real estate developer. She had attended the Museum Art School and had been a student of Louis Bunce. Arlene was able to use her social and business connections to help the Fountain become the premiere gallery in Portland. Jack and Barbara McLarty had begun their gallery with

${ }^{143}$ In Januarry 1997, PSU has approximately 39 instructors v. The Pacific Northwest College of Art with approximately 44 .

${ }^{144}$ McLarty. 
the financial support of a handful of patrons and artists, but without the social and business connections of Schnitzers, the Image Gallery remained a smaller concern, best described as an art gallery for artists, run by artists. The Fountain and the Image both closed in the mid-eighties, but by that time numerous other galleries were operating in Portland.

Many factors contributed to the expansion of the Portland art market: individual collectors were becoming more familiar with modern art; through their interior decorators and architects, Portland corporations bought many works; and, especially during the Reagan era, modern art became a investment vehicle. By 1997 the art community could boast of over a dozen art galleries featuring modern art. 


\section{Part Two:Theoretical Discussion}

Art controversies provide an unique opportunity to analysis art's functions of demarcating the cultural divides in our society. It is during the rare art controversies that the foes and allies of art are most candid and their positions most easily identifiable. While art controversies generate considerable attention and furor, it is important to realize that the great majority of art is produced and displayed without the comment of art world outsiders. This leads to the central questions of this thesis: what are the social factors that lead to the eruption of art controversies and how do these factors determine the outcome of controversies? To understand this we must first explore what defines the boundaries of the art world and the social positions of the participants in the controversies.

The sociology of the arts has for the most part neglected analysis of art controversies; those who have attempted to understand controversy relied heavily on the ideological interpretation of works. The Portland cases involved abstract art, an art ostensibly free of ideology. Unlike a Robert Mapplethorpe photo or a Diego Rivera mural, Bunce's airport mural and the Centennial exhibition do not provide ideological visual clues. How the foes of 1950 s modern art ascribed ideological meaning to these works is another question that deserves exploration.

\section{Related Theory}

One of the most cited works in the sociology of the arts is Howard Becker's Art Worlds (1984). This work is helpful in defining the scope of the art world in 1950s Portland. Becker's book, while primarily concerned 
with the social context of the artist, also discusses the role of the audience in interpretation of art. Becker argues that conventions guide the interpretation of art within the art world.

Using Becker's typology, we can describe the Portland modern art world of 1958. It would include painters like Louis Bunce and Jack McLarty, academics and Museum officials such as Gordon Gilkey and Bill Givler, art patrons including Hawley Hoffman, and art students like Arlene Schnitzer. This group would have been in agreement on the conventions of modern art. Louis Bunce was an integrated professional: an artist whose work fell within the conventions and consistently found an audience. Becker implies that those artists whose works are too avant-garde -- or stretch conventions too far (i.e. Charles Ives or Simon Rodia) -- find resistance from their audience and thus are neglected and ignored. With accolades from Life magazine and one man shows at the Portland Art Museum, Bunce was clearly not doing work that was outside of the contemporay art world's conventions.

Again applying Becker's typology, the members of the Port Commission who initially rejected Bunce's airport mural and those citizens who actively protested the mural were outside of the boundaries of Portland's modern art world. Becker does not discuss the active opposition of an artist's work by those who are outside of the artist's art world, but one can imply that such opposition may stem from distaste for work which does not share the conventions of their own world. Comments from commissioners such as, "What is it?" support a claim of a fundamental misunderstanding of the art world conventions. It is notable that the Port 
commissioners turned to the Portland Art Commission to evaluate the Bunce mural. The Portland Art Commission was composed of individuals who were members of the Portland art world. The Art Commissioners reported back to the Port that the mural was within the conventions of modern art. With this reassurance, the Port reinstated Bunce's commission.

While the Port's action may thus be described, Becker's typology does not explain the motivation behind the vehement opposition to the mural (and later modern works in Oregon) by "average citizens." In the case of Mrs. Murphy, it can be assumed that some of her motivation was due to seeing resources being spent on an artist like Bunce at the expense of artists like her husband, Chester. But most of the other realistic artists who chose to participate in the controversy had no monetary interests at stake. Becker does explore the reasons why governments censor artists. He explains censorship by looking at the political content of works. He states: "Political leaders usually believe that the symbolic representations embodied in both high art and popular art affect whether citizens can be mobilized and for what ends." 145 It is from these beliefs that censorship arises. While on several occasions Mrs. Murphy and others did express concern that modern art was part of a communist plot, it is not clear that this was the primary motivation for their mobilization in opposition to modern art. More frequently Murphy and the others asserted that abstract

145 Becker, Howard, Art Worlds, (Berkeley, CA: University of California Press, 1984), p. 166. 
art is "ugly," and that a hoax on the taxpayer was justification for their crusade.

In Arresting Images (1992), Steven Dubin investigated the art controversies that erupted in the 1980's and early 1990's. The book primarily chronicles these events, although Dubin does outline a weak theoretical framework for understanding the cause, likelihood, and outcome of art controversies. Dubin argues that art controversies are likely to occur when there is a "high degree of communal fragmentation, widespread civic malaise, and low communal morale. What becomes controversial are generally those works which address volatile, unsettled issues. And where this takes place is most typically at strategic public locations." 146 Looking at the airport and subsequent controversies we can identify one factor that is consistent with Dubin's framework. The airport and the Centennial were both "strategic public locations." However, the other elements of this framework are only peripherally applicable to these controversies. The Bunce mural and the other works did not address volatile and unsettled issues in their content unless we make an assumption that the medium of abstract expressionism is in and of itself volatile and unsettling.

In the letters and literature of Mrs. Murphy, there is a linking of abstract art to moral decay and anarchy, but none of the letters contend that the specific objectionable art works were addressing broader social issues.

146Dubin, Steven, Arresting Images: Impolite Art and Uncivil Actions, (New York: Routledge, 1992), p. 38. 
Regarding Dubin's assertion as to when a controversy develops, there is little indication that Portland suffered from low communal morale, communal fragmentation, or civic malaise. However, Mrs. Murphy and the other members of CCAO obviously felt somewhat isolated and removed from the decisions public officials made regarding public art, and an argument can be made that this alienation constituted some form of communal fragmentation. Dubin's concept of communal fragmentation would not include this instance. He described communal fragmentation in terms of race, gender, or religious differences, not aesthetic differences.

Dubin suggests that controversies are created by "governments to divert attention from pressing social problems, by moral entrepreneurs, and by groups who feel their values are threatened by what is depicted." 147 Again, applying these criteria to the Portland controversies proves difficult and unwieldy. Mrs. Murphy can be portrayed as a moral entrepreneur who used the Portland controversies to create status and prestige for herself. From all reports Mrs. Murphy thrived on the attention accorded her, but there is no evidence that her beliefs were not sincere and deeply felt, nor did she use the controversy to further political ambitions. We must assume that the abstract art was threatening to its opponents and explain why they felt so threatened. Unlike the controversies that Dubin explored, the prima facie explanation of objectionable content in the airport mural simply does not exist. Dubin's dependence on the ideological content of the

${ }^{147}$ Beisel, Nicola, "Morals Versus Art: Censorship, The Politics Of Interpretation, And The Victorian Nude", American Sociological Review, vol. 58, (1993), p. 146. 
work to explain art controversy is inadequate as well, for it does not explore why this art was threatening.

In "Morals Versus Art: Censorship, The Politics Of Interpretation, And The Victorian Nude," Nicola Beisel (1993), argues that Dubin's model fails to account for the censorship in a particular case that she examined. Beisel analyzed the 1887 obscenity trial of a New York gallery owner and found that "people of similar social positions held very different opinions about morality and art"148 and that all of the key combatants in the controversy were of the same class. The controversy did not pit one class against another. The upper class ignored the censorship of a small merchant selling nude photos, but actively protested the censorship of a gallery owner selling the same photos. Beisel suggests that this contradiction has a structural basis, as the "arrest of a leading art dealer for selling the photographs cast doubt on the moral purity of the upper class itself."149 Beisel maintains that the arguments for or against censorship in this case were made in ideological terms of class. Beisel also argues that in any art controversy, the strength of the competing meanings of works of art must be considered:

I argue that interpretations of cultural objects gain power by: (1) drawing on cultural schemas that constitute and are constituted by social structures such as family relations and relations between classes, genders, and ethnic groups; and

148 Ibid., p. 160.

${ }^{149}$ Ibid., p. 145. 
(2) allowing adherents to construct attractive images of themselves. 150

Biesel's argument does offer some insights into the Portland controversies. Portland's modern art world in 1958 constituted a small and highly-educated group of people well-placed in society. Participating as a patron in that group afforded affluent individuals like Hawley Hoffman an opportunity to use their prestige and influence to construct an image of themselves as progressive and forward thinking individuals. Likewise the artists, architects, and museum officials associated with modern art felt that they were involved in a noble endeavor benefitting all of society. It is not a large leap to claim that critics of modern art were calling into question the moral purity of Portland elites and the artistic community. Mrs. Murphy and other critics of art waged a moral crusade against modern art, especially modern art produced at the taxpayers' expense, attributing the evils of godlessness and communism to this art. When people like Mrs. Murphy called modern art "ugly" and "a hoax", these critics were also attacking the positive image that the patrons of modern art had constructed for themselves and their authority to decide what taste was. They attacked the moral right of the elite of Portland, and their proxies -- the art professionals, to regulate artistic production. The missing piece to Biesel's explanation of this art controversy pertains to how abstract art came to hold different meanings for those who participated in the Portland controversies. 


\section{Putting the Portland Controversies in a Bourdieuian frame}

Pierre Bourdieu is a theorist whose analysis gives insights into how different actors in a controversy arrive at their differing interpretations. Pierre Bourdieu's concepts of cultural production provide an excellent model for examining the social context of the Portland art controversies. Becker and other social theorists have examined the integrated roles of art world participants. Bourdieu expands these insights and provides us with topologies that allow for exploration of status both within the art world and between the art world and the rest of society.

\section{Bourdieu's Fields}

Central to Bourdieu's model of cultural production is the concept of field. All social formations are structured by a series of fields, encompassing varieties of power relationships (the economic field, the educational field, the religious field, the political field, the cultural field, etc.). Each field is relatively autonomous, "a structured space of positions in which the positions are determined by the distribution of resources or capital."151 Thus, the structure of each field is dependent on the positions of the actors who are operating in that field at the moment. Each field, while operating with different relations of power, is nevertheless homologous in structure to the others and reflects the greater framework: the field of external power, or, as Bourdieu occasionally refers to it, the field of social classes. This all-

${ }^{151}$ Corsaro, William A.,"Review: Language and Symbolic Power by Pierre Bourdieu", Social Forces. Vol. 71, No. 1, (1991), p. 242. 
encompassing field establishes the social hierarchy of economic and political power.

In the Portland art controversies during the late 1950s we can imagine three Bourdieuian fields that are of interest: the field of cultural production, the larger field of class relations, and the field of dominant power. The field of cultural production comprises many sub-fields, for example, fields of popular music, classical music, photography, literature, modern visual arts, etcetera. For this discussion I am using the term field of cultural production to refer to what Becker would call the visual art world.

In each field, agents compete for control of the resources that are particular to that field. Position and power are functions of each actor's capital within his field. Unlike Marx, Bourdieu's concept of capital is not limited to material assets, but rather encompasses any set of resources "that can be used to influence the behavior of others or to aid in the achieving of goals."152

Bourdieu identified four basic forms of capital: economic capital, symbolic capital, social capital, and cultural capital. The distinctions between the four forms are found in their different types of claims on "reified or living labor."153 Economic capital parallels Marx's conception of capital-money, means of production, property, and other material assets.

${ }^{152}$ Smart, Alan, "Gifts, Bribes, and Guanxi: A Reconsideration of Bourdieu's Social Capital." Cultural Anthropology, Vol. 8, No. 3, (1993), p. 393.

${ }^{153}$ Ibid., p. 390. 
Symbolic capital consists of all forms of accumulated prestige or distinction (i.e., celebrity status, academic degrees, renown attached to a family name). Social capital is the system of obligations linked to a network of mutual acquaintance. Cultural capital is the knowledge or internalized code which equips the "social agent with empathy towards, appreciation for or competence in deciphering cultural relations and cultural artifacts." 154 The acquisition of cultural capital is through family, formal education, and interaction with other educated persons within the field.

Of the four types of capital, symbolic and social capital are hardest to separate conceptually. "Symbolic capital involves claims by the possessor that he or she be treated in a particular way by classes of others. Social capital consists of claims to reciprocation and solidarity from particular others." 155 Another distinction must be made concerning education and its relation to cultural and academic capital, a form of symbolic capital. Institutionalized education can increase both types of capital; it can confer a degree which increases symbolic capital, and it can also increase one's cultural capital by enlarging the scope of one's knowledge of cultural artifacts and cultural relations. These four forms of capital are distributed unequally across classes. While under certain circumstances these differing forms of capital can be converted into other forms, (i.e. an academic degree can further one's status in the job market), they are not necessarily

${ }^{154}$ Johnson, Randal, "Editor's Introduction", The Field of Cultural Production: Essays on Art and Literature, (New York: Columbia University Press, 1993), p. 7.

${ }^{155}$ Smart, p. 389. 
equivalent. Possession of one type of capital does not imply possession of other forms.

\section{Field of Dominant Power}

Bourdieu conceptualized the field of social classes as the space of positions that encompasses all of society. Within this larger space, he identifies the field of dominant power. Actors in this field compete in political and economic battles. While Bourdieu does not identify a separate field of political power, one can easily imagine a subdivision of the field of dominant power into sub-fields such as political power. In this discussion of the dominant field of power, I will treat it as one unified space.

The field of dominant power would thus be that portion of society which contains enough economic, symbolic, social, and cultural capital to have a credible impact on struggles that structure the larger field of social class. Examples of individuals or professions that would fall within this category include politicians and academics. Artists and academics are included in the field of dominant power because of their role in creating and maintaining the cultural capital that differentiates the elite members of society from the middle class. Ortega y Gassett and other theorists have noted before the class distinguishing function of the modern art world. In return for creating the artifacts that create class distinctions, the artist receives social and economic capital. Bourdieu's topologies show the reciprocal relationship of the artistic producers with the other members in the field of dominant power. The actors in this field would vary in the amount of each type of capital that they possessed, thus dynamics of the field could be analyzed by plotting the positions of each actor according the 
amount of each capital that the actor personally possessed. For example, consider the two dimensions of cultural capital and economic capital in the mid 1950s. This chart treats economic and political capital as synonymous, although these two capitals could also be used to plot yet another dimension.

Figure 37: Field of Dominant Power

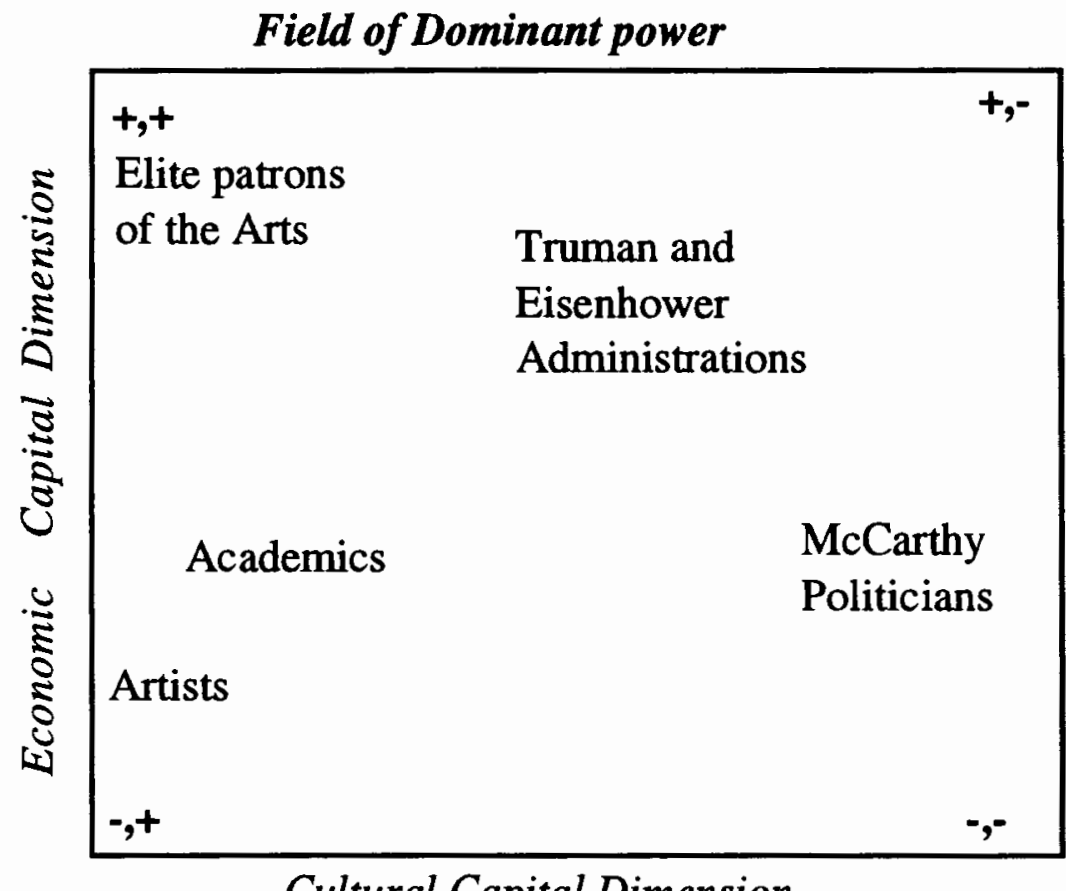

Cultural Capital Dimension

This is by no means a comprehensive plotting of all the actors from this period, or even merely from the context of the modern art controversy alone.

Within the field of dominant power, two related struggles can be examined: McCarthyism and Anti-Intellectualism. McCarthyism can be 
easily identified with particular political actors: Senator Joseph McCarthy, Senator Richard Nixon, and FBI Director J. Edgar Hoover. The McCarthyist movement can also be associated with a particular time: 1947 to 1954 . Antiintellectualism, a much broader phenomenon, is much harder to tie to specific individuals or to a specific time period. The Anti-Intellectual phenomenon operates throughout the entire range of the field of social class, and can be characterized not only as a series of struggles, but more importantly as a disposition or habitus. The influence of AntiIntellectualism shall be discussed in greater detail later when the topic of habitus is explored. The struggle over McCarthyism can be pictured in the encompassing space between McCarthy politicians and academics and artists. (See Figure 38.)

The chart of the field of dominant power in Portland in 1958 is roughly similar to the previous charts (Figure 39). We can easily place Hawley Hoffman in the upper left hand corner. With a Harvard education, a family tradition of participation in the arts, political influence and wealth, Hoffman clearly demonstrated both cultural and economic capital. Because of their dependence on elite patrons like Hoffman, Louis Bunce and other artists would be located in the lower left corner. Political officials like Dennis Lindsay and other Port Commissioners would be located in the upper right hand corner. While they wielded both political and economic power, they deferred to Hoffman and others rich with cultural capital. Mrs. Murphy and other opponents of modern art would be located in the lower right corner or even outside of the field. 
Figure 38: Space of McCarthyism

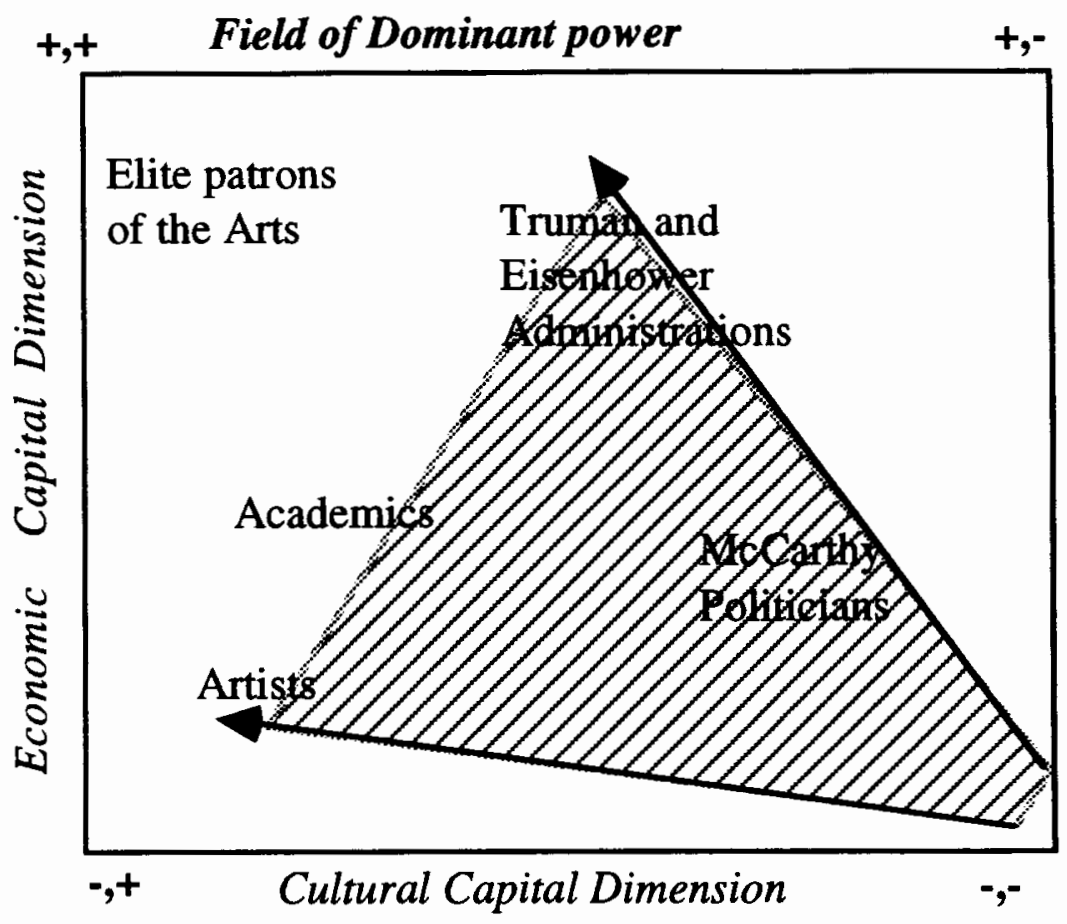


Figure 39: Field of Dominant Power, Portland, 1958

Field of Dominant power

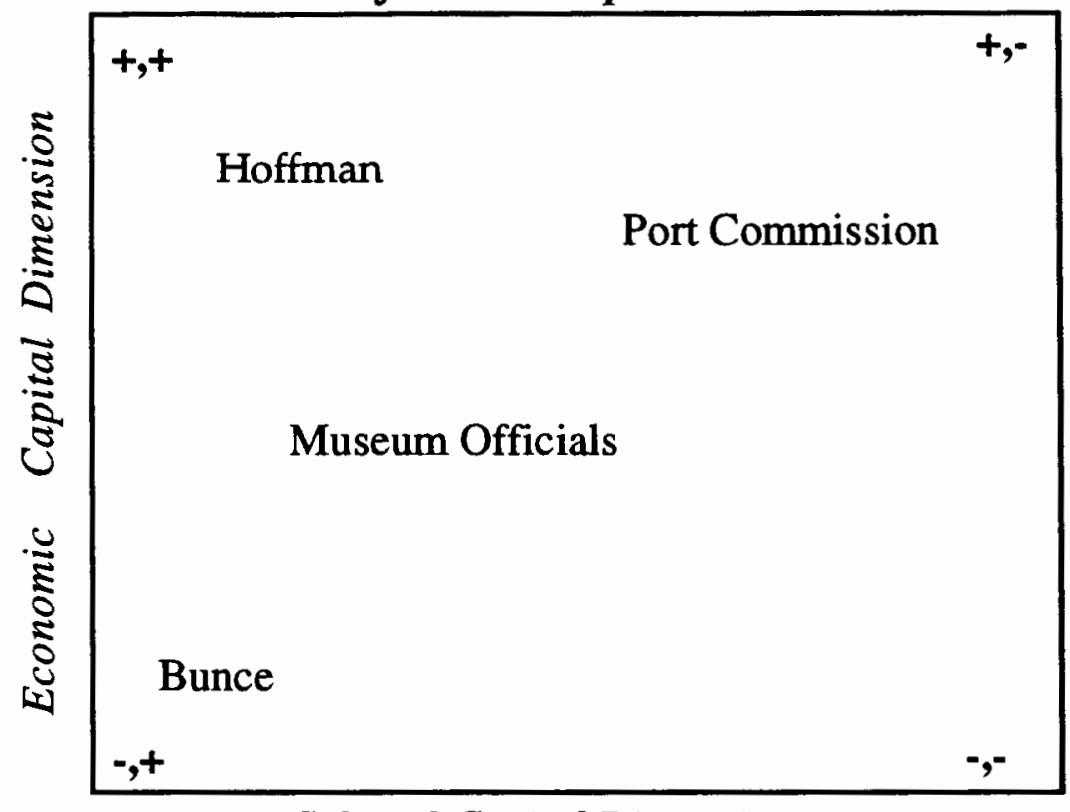

Cultural Capital Dimension

Murphy 


\section{Field of Cultural Production}

In his essay The Field of Cultural Production, or The Economic World Reversed (1993), Bourdieu embarked on an analysis of not only cultural works and their creators, but also on the underlying questions of what makes those works possible, how they are consumed, and how the creators of those works position themselves within the framework of the field. Every effort is made to place the works within a social context without creating a class-deterministic reading of the works that does not account for the individual's strategies and position-taking. On the other hand Bourdieu echoes his work in the Love of Art and rejects the 'art for art's sake' charismatic explanations as well.

The literary and artistic field is just one of many contained in the encompassing field of power. It contains not only the direct producers of a work - the artist, composer, and the writer - but also encompasses those who contribute to the meaning and value of the work - the critic, the publisher, the gallery director, and all others whose combined efforts create consumers capable of recognizing and appreciating art. Thị field would even include the parents and teachers of future art patrons. For recognizing this large and diverse set of agents involved in the production of art contributing a view of collective action - Bourdieu credits and lauds Becker. However Bourdieu criticizes Becker's model for only providing for interaction among the art world and not accounting for the position-taking inherent in Bourdieu's own model. 
Figure 40: Greater Field of Power Relations

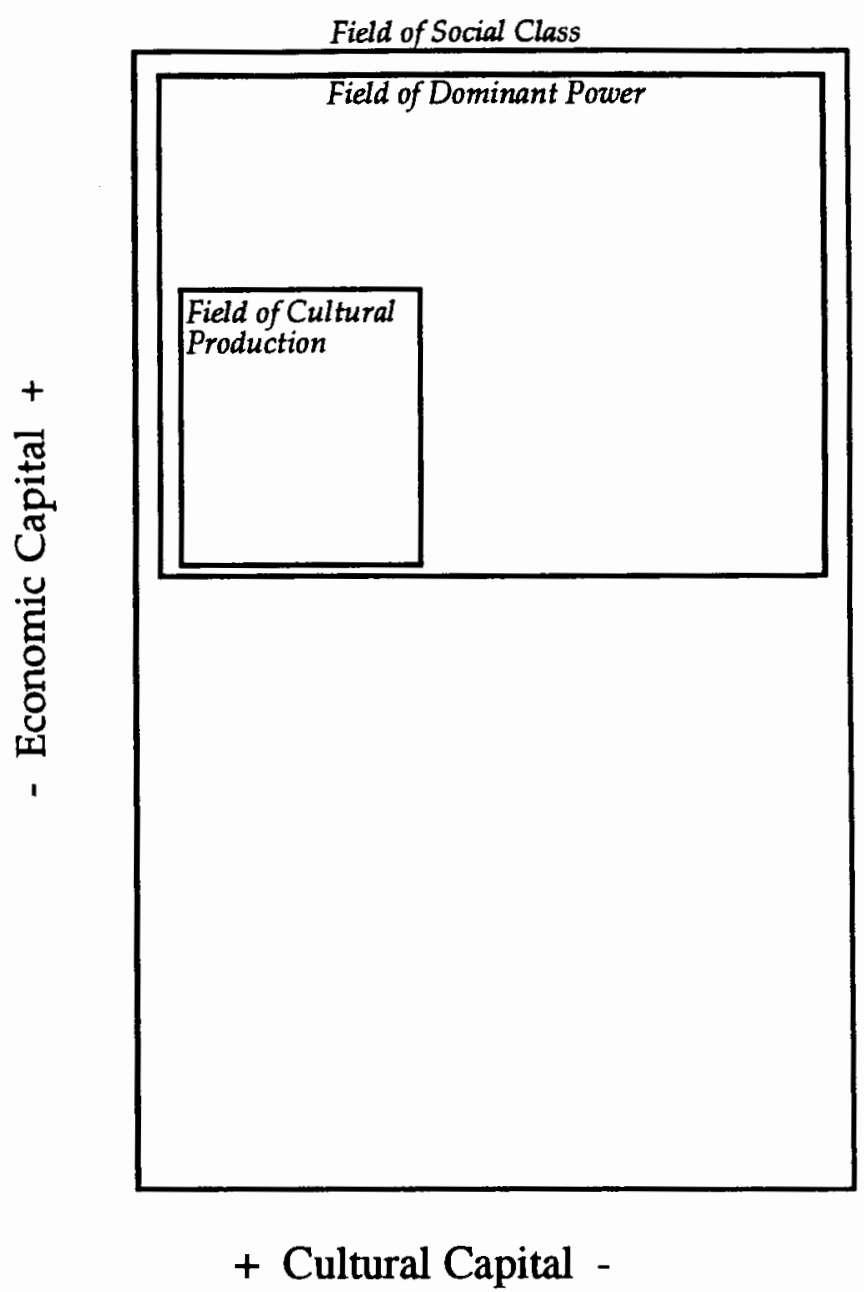

The field of cultural production is relatively autonomous in relation to the field of power. It creates its own hierarchy based on its own economies of capital. The field is located in the dominant end of the greater field of power; however it rests near the bottom of the hierarchy of the dominant. (See Figure 40) Thus Bourdieu describes the cultural field as the 
"dominated of the dominant."156 This field is located in the dominant end, for it possesses a high degree of symbolic capital (e.g. academic capital, cultural capital). Different sectors of the field vary in their insulation from the power structure of the greater field as a whole. For example, a playwright is among the least insulated because the economies of the box office dictate success in his/her sub-sector. The more that a field is independent of the greater field (economic and political capital) the more that field is able to create its own independent criteria of success (symbolic capital). Symbolic poetry is an example of a nearly autonomous subsection. In this subsection the "loser wins." "It is based on a systematic inversion of the fundamental principles of all ordinary economies: that of business (it excludes the pursuit of profit and does not guarantee any sort of correspondence between investments and monetary gains), that of power (it condemns honors and temporal greatness), and even that of institutional cultural authority (the absence of any academic training is considered a virtue)."157

This represents, as Bourdieu expresses, an "anti-economy". An order develops based on disinterest of economics. The gallery "owners and publishers operate within their own subsection of the field which is less insulated from the greater field but within which the hierarchy of these agents is homologous to that of the artists. Thus, the artist has a corresponding agent who shares a corresponding rank in the subsection of

156Bourdieu, (1993), p. 41.

157Ibid., p. 39. 
the intermediary. It is the gallery owner, museum official, and the publishers' role to further the artist's disinterestedness by insulating him/her from the market. It is in these intermediaries' best interest to maintain the reality as well as the charismatic myth of disinterest in the market. These agents, along with academics, art critics, art instructors, patrons and others convert the artists' inverse capital into capital of use in the greater field. Artists and their supporters have an interest in disinterestedness to maintain the illusion of art for art's sake.

Artists like Louis Bunce and Jack McLarty were both artists who depended on intermediaries to help maintain the myth of disinterest in the market. By working for the Museum's school, they could receive monetary rewards for being artists. When they were proprietors of galleries they both asserted that they were artists first and running their galleries for the sake of art as whole.

The hierarchization in the cultural field is at all times a struggle between "bourgeois art" and "art for art's sake." At times this struggle reflects the opposition between the mass arts and the high arts, or the subfield of large-scale production of art and the sub-field of the restricted production of art. The artists who operate in the sub-field of restricted production produce for other producers and are "paid" in the symbolic capital of prestige, consecration, and artistic celebrity. This can also be expressed as a battle between two different principles of hierarchization: heteronomous - favorable to those who dominate the field economically; and autonomous - those who seek larger independence from the greater field and view financial success as a sign of compromise. Those who are 
the least insulated and associate their interests with the greater field of power are those who are the least endowed with the symbolic capital that operates in the sub-field. These "bourgeois artists" often find the boundaries of the sub-field drawn excluding them.

It would be hard to label the artists associated with the Oregon Society of Artists as "bourgeois artists" as they did not have professional careers. If there was a bourgeois art world in Portland during this period, it was centered around those wealthy patrons who were buying Oriental, impressionistic, and other pre-abstract arts. No thriving community of bourgeois artists in Portland opposed the modernists. Instead modernists competed with the ghosts of great dead artists. Mrs. Murphy was claiming that members of the Oregon Society of Artist deserved bourgeois consecration, but the only ones consecrated in the field of dominant power were modern artists and dead artists.

The structure of a field is determined by the distribution of the available positions. Examples include the novelist vesus the poet, the striving artist versus the consecrated artist, the bourgeois artist versus the high artist. It is in these conflicts that the homologies within the greater field of power are found. Alliances form between the two fields and artists who occupy a disadvantaged position in the cultural field "tend to feel solidarity with those who occupy the economic and culturally dominated positions in the field of class relations. Such alliances based on homologies of position and combined with profound differences in condition, are not 
exempt from misunderstandings and even bad faith."158 Association with the literary avant-garde and politically radical movements are common examples of these alliances. Bunce and McLarty both participated in progressive movements such as the American Artist Congress and American Artists' Guild. It is notable that when the young abstract expressionists were most politically active was before their art had been consecrated by the mass media and art critics. Among Portland artists, Bunce probably was the most consecrated in terms of cultural capital. While he did not hold a fine arts degree, he had studied in New York and more importantly shown at the high temple of Modernism, the Museum of Modern Art. He had also received recognition by national art critics and a feature article in Life magazine.

Positions in Bourdieu's models also vary in relation to demand. Those in heteronomous positions respond to commissions, or more directly to the market - which may be anticipated or ignored. ${ }^{159}$ The other pole of the field is characterized by its lack of demand. At the pole of demand, a distinction is made between those who produce for the cultural elites and those who produce for the masses. Those who produce for the cultural elites are highly consecrated with symbolic and economic capital. These positions are often within the great bourgeois institutions of art: the opera, symphony, and galleries patronized by upper classes. The hierarchy of demand (Bourdieu uses the term "dependence" interchangeably with

158 Ibid., p. 44.

${ }^{159}$ Bourdieu, (1993), p. 46. 
"demand") and the hierarchy of autonomy overlap, expressing the rank of positions. Thus it is possible to describe fields of cultural production with two dimensions: the range from high to low in consecration, and the range between autonomy to heteronymy. (See Figure 41.)

Figure 41: Concecration in the Field of Cultural Production.

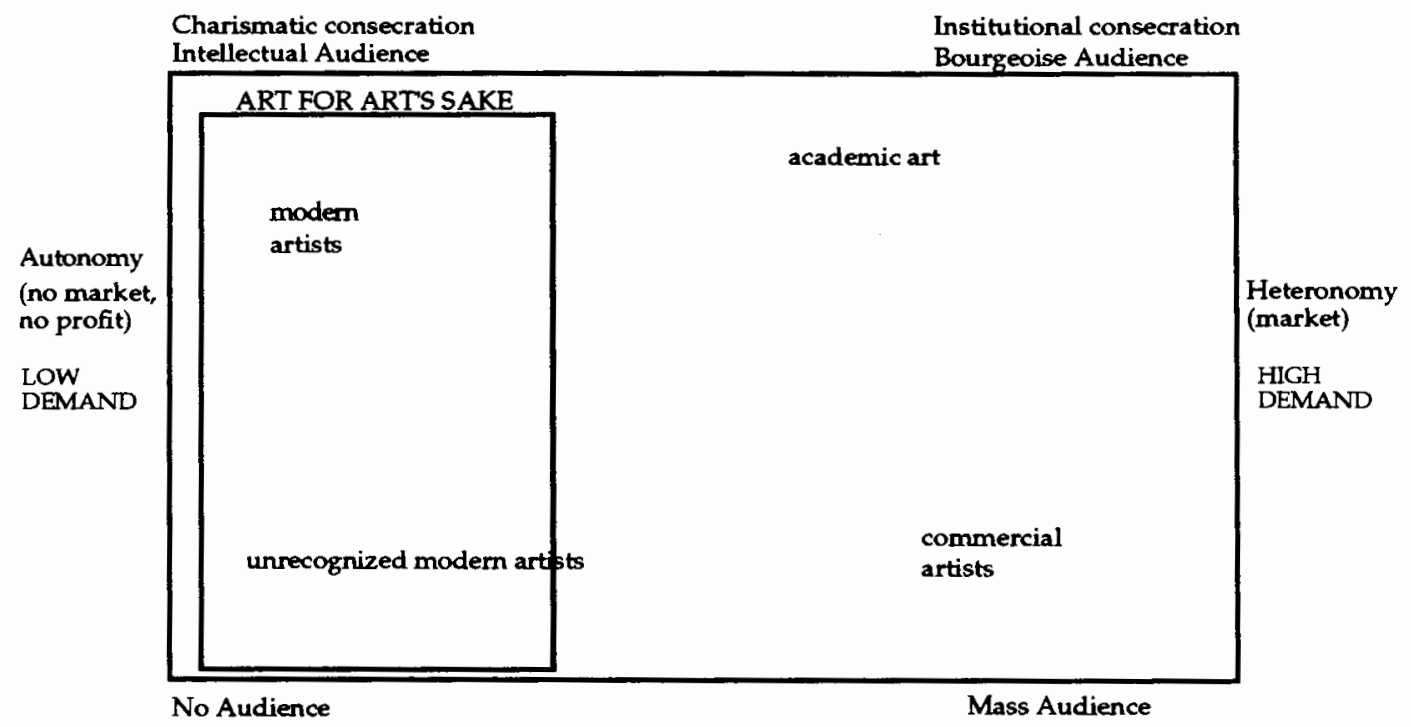

Low degree of consecration

The most constant and consistent cause of internal struggle is between the old artist and the young artist. Each generation of artists seeks out its own position in the field. If we assume that size and composition of the audience fixed, then new positions can only be created by the 
displacement of old positions." Thus a temporal dimension of hierarchy to the field exists. The new position which achieves consecration forces older traditions down the temporal hierarchy. "The avant-garde is separated by a generation from the consecrated which itself is separated by a generation from the avant-garde that was already consecrated when it made its own entry into the field." 160

Figure 42 is an attempt to plot the field of cultural production as it existed in the 1950's. The axes are the dimensions of economic and cultural capital and the plots are the general actors or groups of social actors that were active in the Portland art world. Mrs. Murphy's group, the CCAO, is placed on the border of the field of cultural production and dominant power because of the mixture of people involved with that group. Mrs. Murphy, the leader of the group, was married to an artist who was a member of the Oregon Society of Artists (OSA). Many artists in the OSA were also members of the CCAO.

* It could be argued that the field is constantly expanding to incorporate emergent classes and that this creates new positions. The expansion of the French middle class and the expansion of the market for novels and impressionistic paintings during the 19th century for example.

${ }^{160}$ Ibid., p. 61. 
Figure 42: Field of Cultural Production, Portland, 1958.

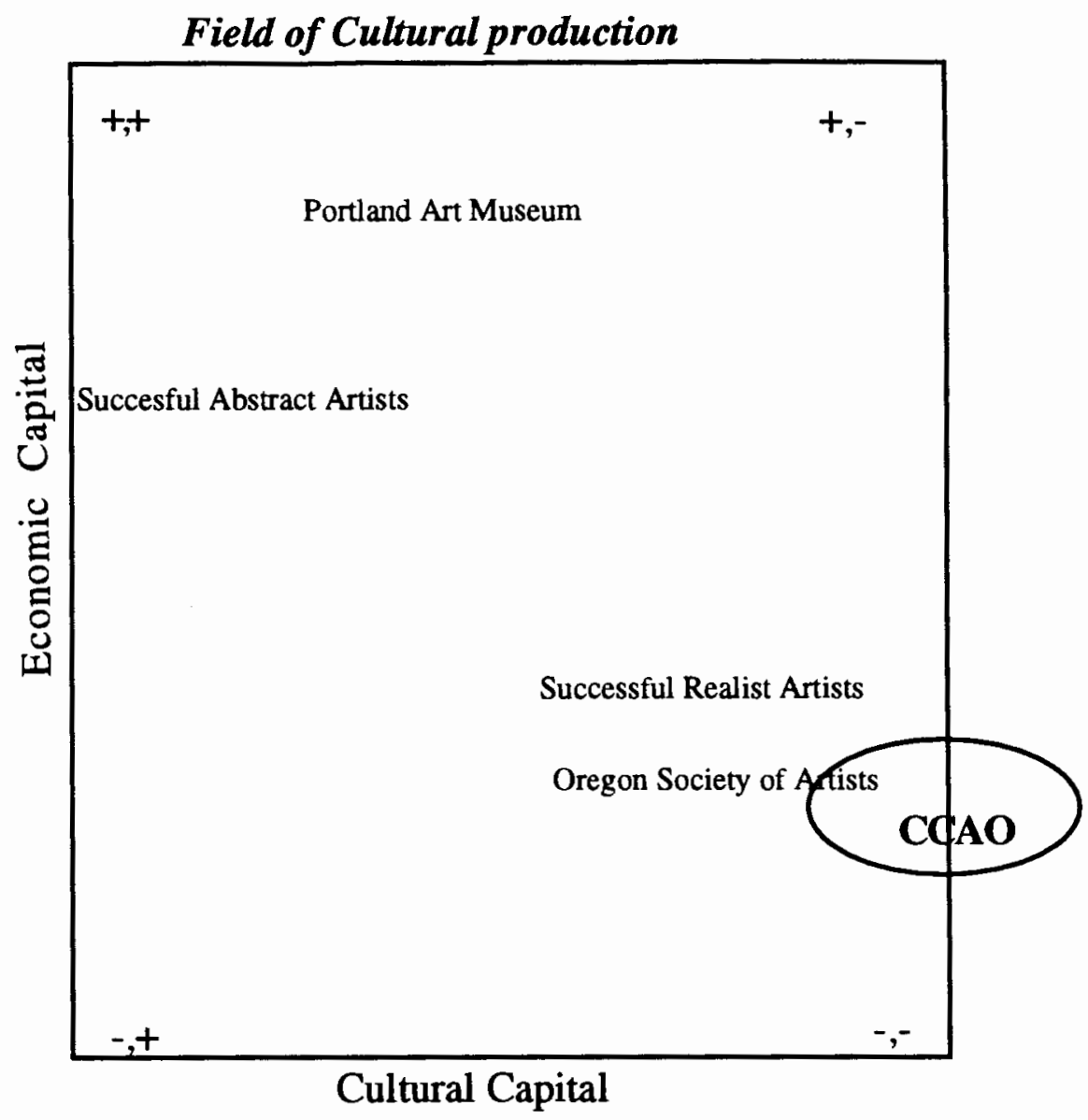

If one plots the space of the struggles that occurred in the field of cultural production between the realist artists and abstract artists during this period one would see a fan similar to that seen when plotting the space of the struggles relating to McCarthyism. (See Figure 43.) 
Figure 43: Space of Cultural Struggle, Realist vs. Abstract.

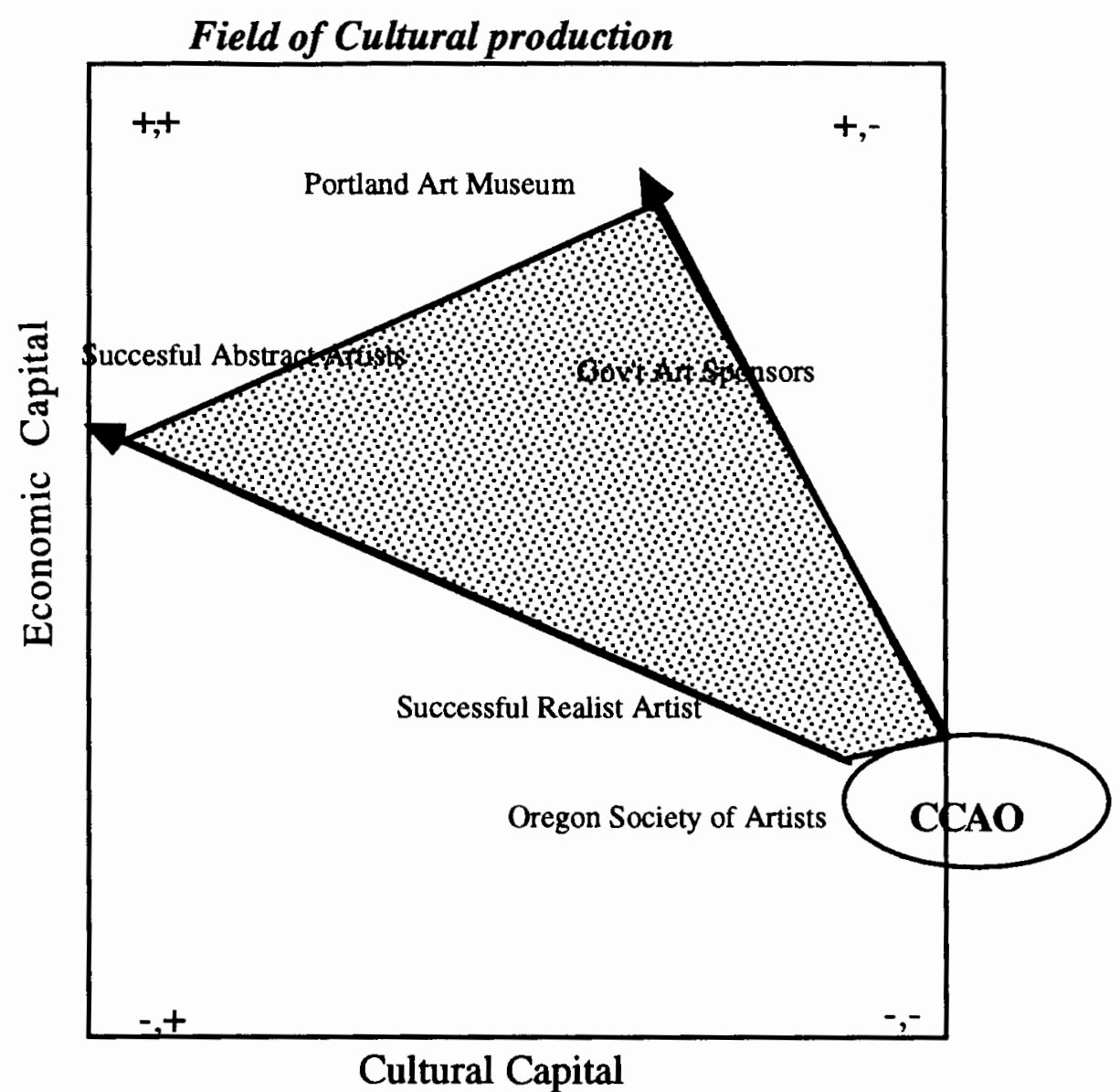

\section{Bourdieu's Habitus}

Boudiue not only provides a way of describing the the field of cultural production, he also provides a way of analysing the artisitic propensities of those who inhabit it. "To understand the practices of writer and artist, and not the least their products, entails understanding that they are the result of the meeting of two histories: the history of the positions 
they occupy and their dispositions." 161 The field is the "space of possibles" to each agent. At a minimum, the agent must be able to perceive available positions. The possession of economic capital must not be overlooked in its importance to success in the cultural field. Private income is the best substitute for sales, as Théophile Gautier said to Feydeau: "Flaubert was smarter than us...He had the wit to come into the world with money, something indispensable for anyone who wants to get anywhere in art."162 Money allows for greater autonomy from the field of dominant power. Bourdieu calls the varying inclinations that are determined by social background habitus.

Bourdieu's concept of habitus consists of those "dispositions that generate practices, perceptions and attitudes which are 'regular' without being consciously coordinated or governed by any 'rule.' "163 It is sometimes described as a "practical sense" or as a "feel for the game" that allows agents to react without a conscious calculation of rules. The habitus is conditioned by the structure of society. People from differing socioeconomic classes will have been exposed to different material conditions which incline them to perceive the world in differing ways. Actors from the same class would be expected to share a common habitus across different fields, allowing the discussion of class habitus. "The habitus is not only a structuring structure, which organizes practice and the perception of

${ }^{161}$ Ibid.

162Ibid.

${ }^{163}$ Corsaro, (1992), p. 242. 
practice, but also a structured structure: the principle of division into logical classes which organize the perception of the social world as itself the product of internalization of the division into social classes."164

Tastes in food or clothing, ase of language, and aesthetic preference in art and music are all reflections of one's habitus. "Transposable," the habitus unifies agents' practices across several fields. The agents' actions in several fields would be "harmonized" without any deliberate "orchestration." In Distinction, Bourdieu gives the example of how the ascetic ethos of savings and recycling associated with a scarcity of resources may appear in several contexts: the use of bank credit or the use of social credit (calling on a favor from a friend for example). Bourdieu offers a paradigm akin to handwriting: writers, once they have learned the form of the letters through endless tracing, produce writing that is distinguishable regardless of the surface, writing instrument, or even the topic. One's habitus is "durable," lasting throughout a lifetime and so deeply rooted to appear natural, obscuring its social origin. Lifestyle is the product of the intersection between one's habitus and fields, the set of choices that result from their union.

It is virtue made of necessity which continuously transforms necessity into a virtue by inducing 'choices' which correspond to the condition of which it is the product. As can be seen whenever a change in social position puts the habitus into new conditions, so that its specific efficacy can be isolated, it is taste - the taste of necessity or the taste of luxury - and not just high or low 
income which commands the practices objectively adjusted to these resources. Through taste, an agent has what he likes because he likes what he has. ${ }^{165}$

Those who are born to families with economic capital develop a habitus that favors the development of a flair of "self-assurance, audacity, and indifference to profit"166 -- dispositions that serve the avant-garde artist well. The privileged are also more inclined to be aware of the possible avenues of cultural expression and seek out new positions which, while appearing riskier, provide a greater reward in the long run. "Thus we find that as a rule those richest in economic, cultural, and social capital are first to move into the new positions (and this seems to be true in all fields: economic, scientific, etc.)."167 Bourdieu notes that the habitus of a potential artist from the lower and middle classes often has a "faulty" sense of "investment." They seek positions that are already dominant, attracted by the economic and symbolic profits. This strategy can fail for two reasons. First, the very dominance of the position thus attract others and may be the space of intensifying competition and resulting declining profits. Secondly, they also may be drawn to sites that are not suitable to their habitus. Failing in their lofty ambition they may find themselves wasting their time as they lack the social capital to succeed in these positions. Bourdieu's description of the tendency of upper class individuals to develop habitus inclined to

165 Bourdieu, Pierre, Distinction, (Cambridge, Mass.: Harvard Universtity Press, 1984), p. 175. 166 Ibid., p. 68. ${ }^{167}$ Ibid., p. 69. 
modern art does not as readily apply to the artists involved in the Portland controversies as it does to the patrons involved. Clearly Hawley Hoffman had the social position, wealth, and elite education to make him inclined to prefer avant-garde art.

Social practices are the interaction between the agent's habitus and the field. The actor interprets the field through the habitus. The field is the arena of power relationships the agent interprets. Bourdieu's concept of habitus and fields does not mean that agents are "cultural dopes."168 Agents are knowledgeable actors who engage in investment strategies to further their capital resources within a field. However, the ordinary actor does this through the habitus, their filter of tastes and preferences. The primary experience of life is misrecognition of the true power relationships. This is in opposition to the Marxist theory of false class consciousness, for the ability to perceive class distinctions is in itself a product of the habitus.

A habitus that is pervasive through American culture is that of antiin tellectualism. It is possible to attribute many struggles that have occurred in this nation's history to this underlying current in our culture. Richard Hofstader in Anti-Intellectualism in American Life (1962) argues that a "resentment or suspicion of the life of the mind and those who are

${ }^{168}$ Sewell, William H, Jr., "A Theory of Structure: Duality, Agency, and Transformation", American Joumal of Sociology , (1992), Vol. 98, No. 1, p. 15. 
considered to represent it"169 $^{16}$ is theme that has reoccurred during many periods in our country's history. Hofstader contends that anti-in tellectualism is a pervasive quality in our society, nurtured by evangelical religions that repudiated the role of higher learning in pursuit of authoritative positions within the church, by a political ideology that extols equality, and a public educational system that reinforces egalitarianism. To Hofstader, McCarthyism is but just another reappearance of antiintellectualism.

Whether analyzing the defeat of John Quincy Adams by Andrew Jackson, William Jennings Bryan and the Scopes Monkey Trial, or McCarthyism, Hofstader argues that anti-intellectualism has emerged from the undercurrent after periods of progressivism. Table 1 illustrates sequences of Hofstader's general argument and highlights how this argument applies to McCarthyism.

Following Hofstader's argument, anti-intellectualism is a habitus associated with the lack of cultural capital. Figure 44 illustrates the space that it occupies in the field of social class. The arrow indicate the general direction of anti-intellectual struggles. Hofstaders arguement implies that because individuals like Mrs. Murphy could not understand a genre of art because of their lack of education, it only reinforced prejudices against intellectual elites.

${ }^{169}$ Hofstader, Richard, Anti-Intellectualism in American Life, (New York: Knopf, 1962), p. 
Table 1: Hofstaders Stages of Anti-Intellectualism.

\begin{tabular}{|l|l|}
\hline Hofstader's Stages & Example \\
\hline Progressive Cause & $\begin{array}{l}\text { New Deal and Progressive Social } \\
\text { Reform }\end{array}$ \\
\hline Cause attracts/recruits intellectuals & $\begin{array}{l}\text { FDR's Brain Trust and American } \\
\text { Artist's Congress }\end{array}$ \\
\hline $\begin{array}{l}\text { Some intellectuals are attracted by a } \\
\text { more radical form of cause }\end{array}$ & $\begin{array}{l}\text { Popularity of communism among } \\
\text { intellectuals during the 1930's }\end{array}$ \\
\hline Cause is attacked & $\begin{array}{l}\text { McCarthyism (attack is delayed by } \\
\text { W.W.II) }\end{array}$ \\
\hline $\begin{array}{l}\text { Extremist intellectuals are linked to } \\
\text { the cause }\end{array}$ & McCarthy's witch hunts \\
\hline $\begin{array}{l}\text { Episode reinforces anti- } \\
\text { intellectualism }\end{array}$ & $\begin{array}{l}\text { Continued suspicion of artists and } \\
\text { intellectuals }\end{array}$ \\
\hline
\end{tabular}


Figure 44: Space of Anti-Intellectualism

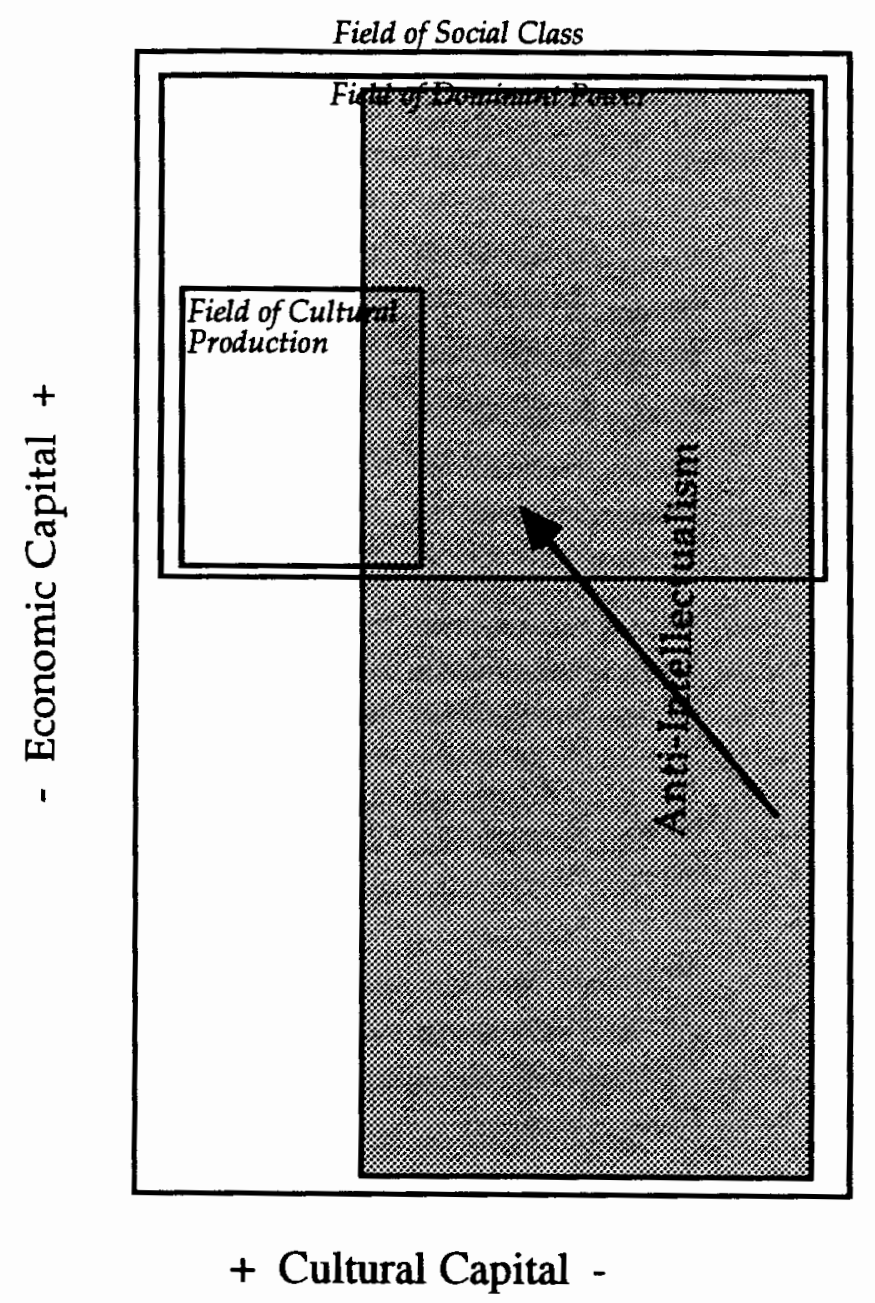




\section{Homologies Between Fields}

Major structural change in Bourdieu's model of the cultural field comes from the "coincidence" of internal and external struggles. Internal struggles occur frequently over position-taking within the field. These antagonisms (e.g.: old artist vs. young, mass vs. high art), are largely independent of changes outside of the field. However, the outcomes of these conflicts depend greatly on the homologies that opposing sides share with external groups who have their own antagonisms.

It is on the issue of internal struggles being a "reflection" of external forces that Bourdieu challenges Lukács and Goldman. They forwarded the idea of the artist being the unconscious spokesman of his class. To Bourdieu this is just an inversion of the Romantic myth of the "charismatic genius." "Without directly reflecting them, the outcome of internal struggles depends on the correspondence they may have with the external battles waged between the classes (or between the factions of the dominant class) and the reinforcement which one group or another may derive from them, through homology and consequent synchronisms."170 One can point to an art revolution and indicate the subsequent changes in positions in the cultural field afterward: winners and losers. Bourdieu argues that the cultural antagonisms existed in most cases long before the revolution of causes internal to the cultural field. Within the field of dominant power, McCarthyism was an attempt to discredit the intellectuals associated with New Deal policies and Democratic administrations. This 
field is imbedded within the greater field of social class. McCarthyism is homologous to the Anti-Intellectualism that operates within the larger field.

When constructing a model utilizing Bourdieu's concepts of fields, it may prove worthwhile to think of Anti-Intellectualism in cultural capital terms. Social actors in any field compete using the various forms of capital. A progressive cause utilizes individuals with the social and symbolic capital derived from special training and academic credentialing. Intellectuals -- and included in this group are abstract artists -- are inclined by their habitus to join and support progressive causes, often the most radical form of these causes. Opponents of the cause attack it by deflating the social and symbolic capital of intellectuals associated with the particular issue by attacking radicals on the fringe of the cause.

David Horowitz in Beyond Left and Right (1997) is one of several historians who have offered a critique of Hofstader's explanation of McCarthyism and other insurgent movements. Horowitz maintains that by portraying these groups as uneducated, paranoid, and backward thinking reactionaries, both the broad social currents in which they exist and the long tradition of anti-elitism populism are neglected. Like other critics of Hofstader, Horowitz also maintains that he oversimplifies the economic, social, and cultural framework of insurgent movements. ${ }^{171}$

171Horowitz, David A., Beyond Left and Right: Insurgency and the Establishment, (Chicago: University of Illinois Press, 1997), p. xi. 
Horowitz notes that rather than emerging in reaction to progressive causes, anti-elitism is always present in American culture. Horowitz links Andrew Jackson's battles over a national bank, the Granger movement, William Jennings Bryan, and McCarthyism to a common distrust of big, "paternalistic government, big business, and a view that east coast bankers were parasites."172 Believing "traditional precepts of individual freedom, self-reliance, and equality of opportunity," these populist movements shared a common concerns about the rise of corporate capitalism, institutional complexity, and the expansion of the state. 173

Horowitz explains that in addition to the tradition of anti-elitism, it is important to recognize the economic and social context of the populist movements. The government had expanded during the New Deal and World War II. Many small business owners perceived that this expansion had favored the unions and big business at the small entrepreneurs' expense. A large number of small businesses had failed during World War II. Foes of big business pointed to this as proof that central planing and wartime collectivism favored the capitalist elites.174 In the 1950s, the Eisenhower administration's relaxation of antitrust enforcement and the increasing number of corporate mergers rapidly changed the economic environment. Social changes also contributed to the perceptions that the federal government and eastern elites were a danger to American values.

172Ibid., p. 9.

${ }^{173}$ Ibid., p. xiii.

${ }^{174}$ Ibid. p. 205. 
In the mid 1950s the administration's lukewarm enforcement of civil rights orders and the deployment of the National Guard to Little Rock, Arkansas gave the perception in much of the South that the eastern elites were usurping local power.

Far from being limited to the isolated and paranoid, Horowitz notes that McCarthyism had a broad base of support. A 1949 Gallup poll found that that 70 percent of those polled believed that "Moscow was building itself up to be the ruling power of the world."175 Another poll showed the majority of Americans believed that communists should be either be killed, imprisoned, "rendered inactive," or at least be watched carefully. Only 17 percent believed that they could hold a civil service job. 176

Horowitz maintains that McCarthyism appealed to a wide array of individuals who "shared an animosity to remote centers of power in Moscow, Washington, and New York." Horowitz quotes Tacott Parson who suggested "support of the movement by powerful interest did not erase the fact that McCarthyism embodied a popular revolt against the upperclasses."

Horowitz describes how the anti-communists of the 1950s considered that the Eisenhower and Truman administrations, big business, and academic institutions were all "duped" by communists who were establishing a "one world order." The anti-communists rallied against the special managerial class, which they saw as saying "that they know what is

${ }^{175}$ Ibid. p. 238.

176Ibid., p. 219. 
good for the people and the people are to do as they are told to do." Alger Hiss, the Rosenbergs, and other celebrated cases only furthered the anticommunists' conviction that academic elites had infiltrated the government. However, the anti-communists also targeted capitalist institutions including the Rockefeller Foundation, the Carnegie Endowment for International Peace, and the International Monetary Fund - groups they saw as full of academic elites with "communist inclinations."177 These and other elite bodies were proof of an elite conspiracy advancing communism. For McCarthy's supporters it was a choice of "Patriotism versus cosmopolitan treason."178 Horowitz agrees with the political historian David Oshinsky who asserts that McCarthyism's "primary targets were not communist but the well dressed, well-educated managers of modern society."179

This criticism of the elite managers of society was not part in reaction to a progressive cause, but a continuation of the America's populist movements. After the waning of McCarthyism, the populist and anti-elite cause was continued by the John Birch Society, Goldwater Republicans and the supporters of George Wallace. As late as the 1990s Ross Perot, Pat Buchanan, and other politicians were appealing to the same anti-elite sentiment.

${ }^{177}$ Ibid., p. 270.

178Ibid., p.267.

${ }^{179}$ Ibid., p.286. 
Horowitz's critique of Hofstader only reinforces the argument that anti-intellectualism shares homologies of interest with anti-elitism and other oppositions of the elite class. The CCAO and Mrs. Murphy, by attacking intellectuals including the modern artists, were tapping into deeper resentments of the elite class that are not necessarily just reactions to the New Deal expansion of government. Horowitz's research suggests that anti-intellectualism and anti-elitism operate at the level of habitus. This habitus is rooted deeper than would be suggested by Hofstader's argument. Anti-intellectualism is not just the result of a lack of cultural capital, but the result of traditions and social-economic situations.

The battles within the field of cultural production over abstract art are homologous to McCarthyism (Figure 45). The direction of the struggle is the same as that of both McCarthyism and the Anti-Intellectualism. The opponents of abstract art, some operating from within the field of cultural production and others outside of that field, attacked it using the rhetoric of McCarthyism.

Ultimately the critics of abstract art were not successful due to the strong homologies that existed between those in economic and political power and the successful abstract painters. 
Figure 45: Homolgogies of Struggles

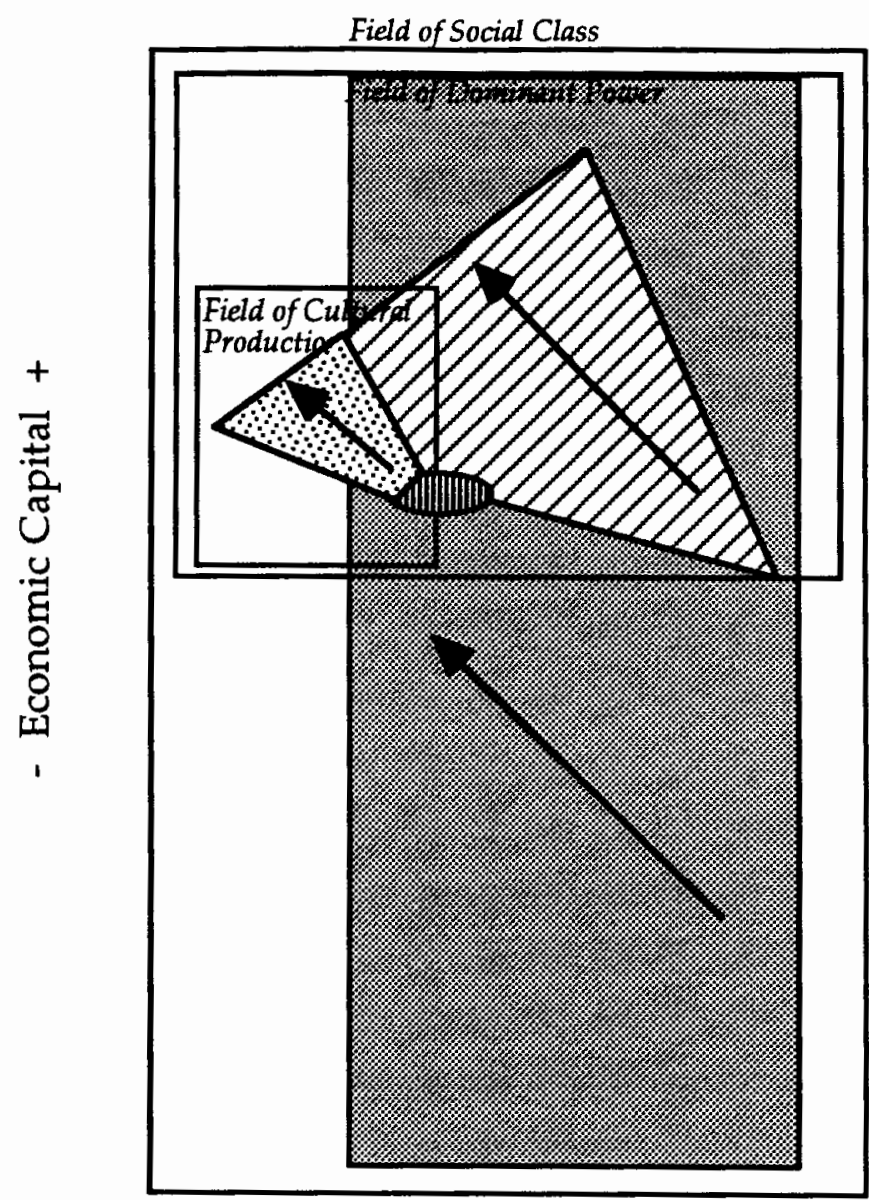

+ Cultural Capital -

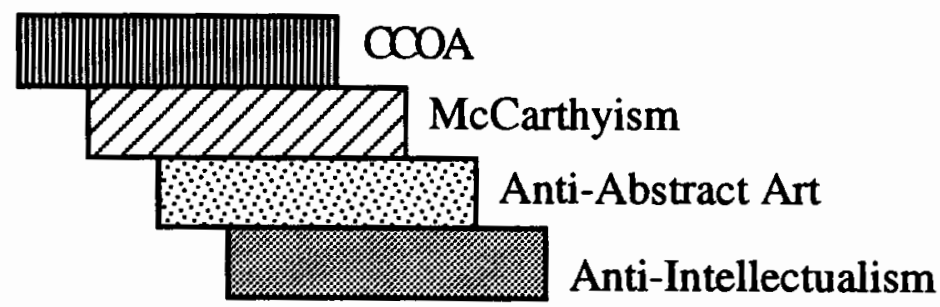




\section{Trajectories, Agency and the Nature of Struggles.}

What objections did the CCAO have to abstract art? Bourdieu's model easily and superficially describes this conflict as rooted in the difference of cultural capital possessed by the CCAO members and the artists and their sponsors. Clearly there was a difference of cultural capital between Mrs. Murphy and Louis Bunce. Differences of cultural capital, however, do not always lead to vocal and vigorous struggles. Many people in 1950 did not understand abstract art, yet only a small fraction of a percent felt compelled to protest it. Analysis of the trajectories of those involved in the conflict can expose some of the motivations for this particular struggle and allow the application of Bourdieu's concepts in a broader and more explanatory way.

Bourdieu defines trajectory "as the set of successive movements of an agent in a structured (hierarchized) [sic] space, itself subject to displacements and distortions, or, more precisely, in the structure of the distribution of different kinds of capital which are at stake in the field."180 It is possible to speak of the trajectory of a particular actor, institution, or even of a school of a particular style. Figure 46 examines the trajectory of those associated with the modern art controversy in Portland. 
Figure 46: Trajectories from 1930s to 1950 s.

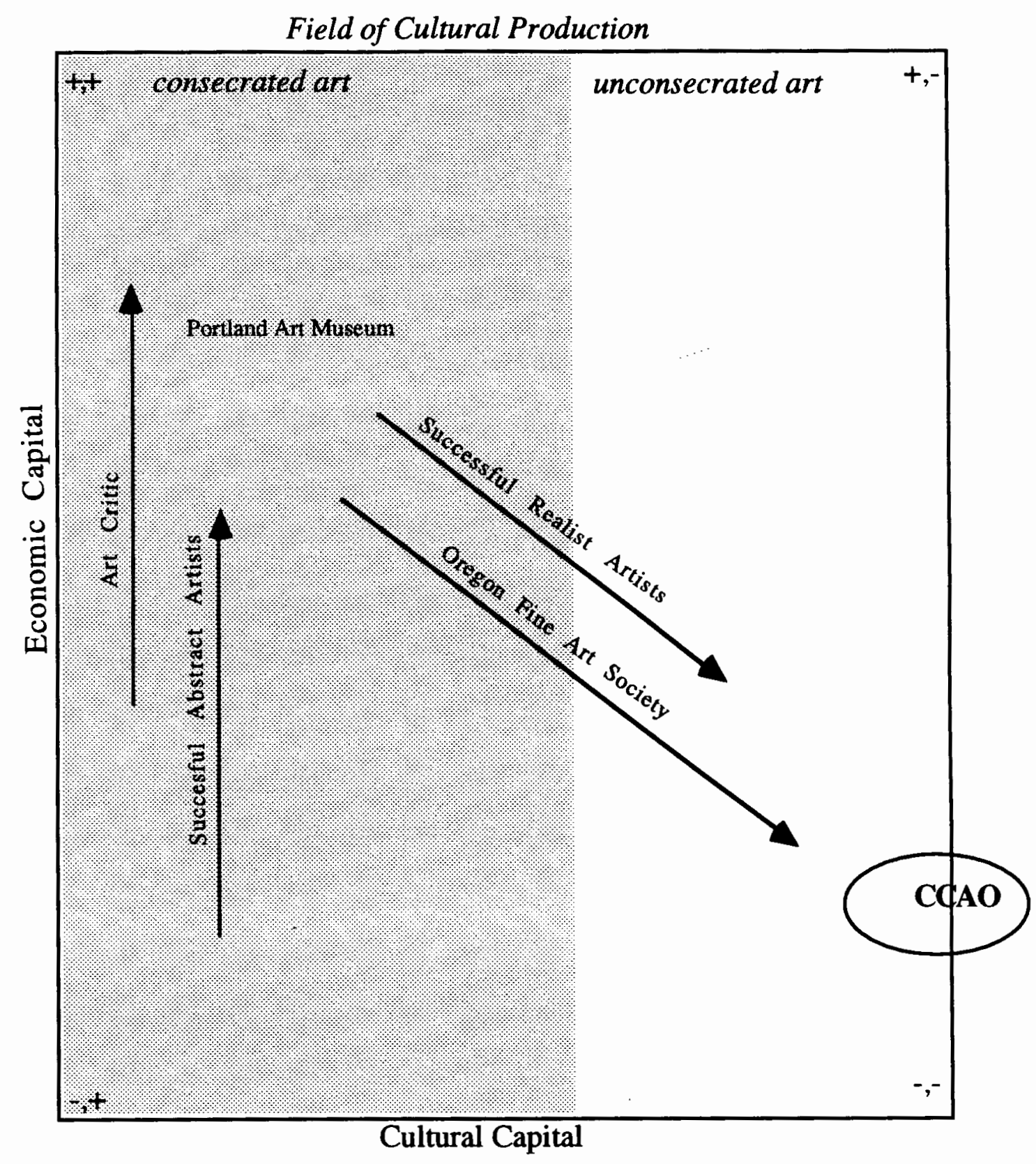


Figure 46 shows that from the 1930's to 1950's the trajectories of art critics* and abstract artists in Portland were pointed upward. This reflects the rise of cultural and economic capital of these two groups during this period. Patronage by corporations, the wealthy, and governments lead to the rise of abstract artists' position in the field of cultural production. Tom Wolfe in The Painted Word described a process he called the "Boho Dance and The Consummation": Critics declare an artist's work to be important; the wealthy who wish to be known as fashionable purchase that artist's work. The artist is in the business of creating the artifact, the critic is in the business of defining the worth of works in the currency of current cultural capital. Both convert their cultural capital into economic capital by their alliance with the wealthy, a reciprocal arrangement. "Today there is a peculiarly modern reward that the avant-garde artist can give his benefactor: namely, the feeling that he (the benefactor), like his mate the artist, is separate from and aloof from the bourgeoisie.....the feeling that he may be from the middle class but he is no longer in it....the feeling that he is a fellow soldier, or a least a guerrilla in the vanguard march through the land of the philistines." 181 While Wolfe was writing about the New York culturatti, his description applies to the Portland art community as well.

\footnotetext{
* I use the term critics loosely. On the local level my use of the term encompasses museum curators, newspaper critics and the academics - anyone who was instrumental in defining abstract art as art. National art critics would also have played a role as important or more important than the local critics; they are included in this trajectory.
}

${ }^{181}$ Wolfe, Tom, The Painted Word, (New York: Bantam Books, 1976), p. 21. 
Tom Wolfe's description of the Boho dance and the class distinguishing role of modern art echoes the concerns of José Ortega $y$ Gasset in his 1925 essay, "The Dehumanization of Art." Ortega y Gasset noted that unlike Romantic art which embraced the populace and was likewise embraced by the populace, modern art is aimed at a minority and creates "irritation" in the majority. ${ }^{182}$ Ortega y Gasset outlined the psychological response that happens in response to modern art:

When someone does not like a work of art, but has understood it, he feels superior to it and has no room for irritation. But when distaste arises from the fact of its not having been understood, then the spectator feels humiliated, with an obscure awareness of his inferiority for which he must compensate be an indignant assertion of himself. Modern art, by its mere presence, obliges the good bourgeois to feel what he is: a good bourgeois, unfit for artistic sacraments, blind and deaf to all aesthetic beauty. 183

The use of cultural knowledge to set one class apart from the masses is what Bourdieu calls symbolic violence. Elites have the power to create structures that legitimize their status. Cultural capital is a product of these structures and demands that the possessors of it be granted privilege and prestige. In modern society, various forms of capital are used to maintain and reinforce class relations. Culture is a structure that produces artifacts which discriminate between classes and also produces the consumers that

${ }^{182}$ Ortega y Gasset, José, The Dehumanization of Art: And Other Essays on Art, Culture, and Literature. (Princeton, N.J.:Princeton University Press, 1968), p. 66.

${ }^{183}$ Ibid. 
can make the discriminations. This differentiation between the classes is created and maintained for the betterment of the upper classes by the actors in the field of cultural production. The actors' motto, "art for art's sake," not only fails to recognize, but also obscures the class-dividing nature of cultural products. "Art for art's sake" is in reality, art for the elites' sake. Many art critics like Jonathan Harris in Modernism and Culture in the $U S$ A, 1930-1960, (1993), maintain that abstract expressionist art's lack of overt political content made it the ultimate capitalistic art. Abstract art was easily commodified and did not offer a critique of the capitalist. It was a product of expression (Pollock), or a mystical icon (Rothko), but most importantly it was not a social criticism of the patron, unlike the critique of J.D. Rockefeller by Rivera.

By the 1950's the Portland art community had developed to a point where it could be characterized as semi-autonomous - defining cultural capital in its own terms (or least in the terms of national art critics). Artists like Bunce and Carl Morris had been consecrated by outside agents including Life magazine and the Museum of Modern Art. By this time the positions of the realist artists and organizations like the Oregon Society of Artists were clearly weakened. They had become marginalized in the field of cultural production, and replaced by abstract art. This marginalization translated into the loss of prestige for realist artists and the loss of influence by these artists in art institutions. For their patrons it meant that they were no longer abreast with the style of the day. They no longer had the cultural capital to discuss the latest art. The realist art patrons' influence in the art institutes was weakened as well. 
Figure 47 provides a schematic of the CCAO controversies. Point 2 shows the force of symbolic violence that the realist artists and their patrons felt. It also shows the economic and political estrangement that occurred when the style favored by these artists was no longer sponsored by the leading art institutions in Portland. The realistic art community's banishment from the art community occurred at the same time the powerful force of anti-in tellectualism reoccurred in the form of McCarthyism. The CCAO was able to attack the art community in what they perceived to be its Achilles' heel, communist artists. Just as important in the accusation of communism was the criticism of abstract art as a foreign "ism" fostered by museum elites at the expense of local artists and taxpayers. 
Figure 47: Schematic of the CCAO Controversies.

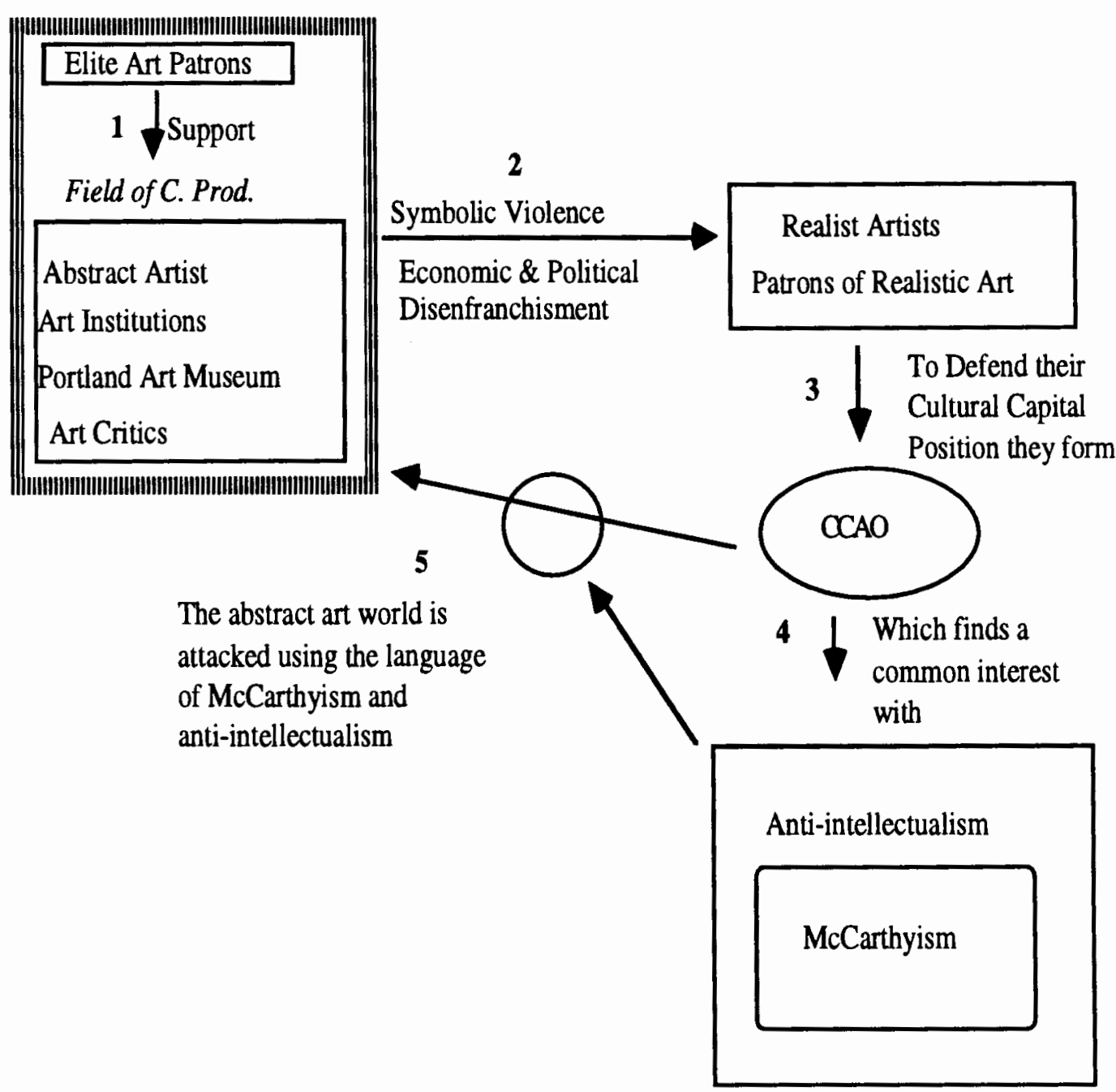




\section{Conclusion}

The following list summarizes the factors offered by Becker, Dubin, Biesel, and Bourdieu that are necessary for the birth and development of an art controversy. These factors are applicable to the Portland modern art controversies and may be generalized to analyze all art controversies:

A) The centrality and symbolic importance of the placement of the controversial work.

B) A community that does not share a common agreement over the conventions that define art work, or in Bourdieuian terms, a difference in cultural capital between the actors involved.

C) Resentment arising from the class demarcation inherent in the cultural capital value of the art. This resentment can be expressed as criticism of the elite class or their cultural proxies, the consecrated artist.

D) An ability of the critics of art to convert their cultural capital deficit into political capital by utilizing homologies of interest with broader ideological issues.

In addition to these factors, three other factors are critical to the eruption of art controversies and are illustrated by the analysis of the modern art controversies in Portland.

E) An opportunity for the public exposure of the processes of cultural production arising out of a failure of elite coordination of consecration.

F) A series of controversies, or a prolonged extension of one controversy, that allow participants time to establish positions and strategies. 
G) A positioning of both the cultural producer and the cultural critic to maintain the "anti-economy" of their positions.

It is doubtful that the controversy over Louis Bunce's airport mural would have erupted during the Port Commission's meetings had Hawley Hoffman not been on vacation. Hoffman represented the elite Portland interests who had consecrated Bunce as the most eminent local modern artist. In Hoffman's absence the members of the Port of Portland, lacking the cultural capital to decipher the work and its symbolic value, openly questioned Bunce's standing as a consecrated artist. The Port's reliance on the Portland Art Commission to reaffirm Hoffman's choice was tantamount to a re-consecration of Bunce and a affirmation of the art world's and elite's right to chose and consecrate artists.

It is notable that it was only after the airport mural controversy that Mrs. Murphy was able to organize, articulate, and mobilize opposition to modern art. The fact that the opposition to Bunce's art was based on the perception that it was a monstrosity, ugly, and indecipherable is significant as well. The gap of a year between the airport mural controversy and the later controversies allowed critics like Mrs. Murphy to form the coalition of realist artists and their supporters into a organized opposition. It is with the creation of the CCOA that letters to the local newspapers begin linking communism and modern art. The series of controversies can be linked by the opponents to provide "proof" of a conspiracy or moral decay.

Art controversies have consequences that extend long after the intial disputes. Viewed in a broader context, the series of Portland art controveries that occured in between 1958 and 1961 can be linked to later 
Portland controversies like the seclection of art at the remodeled Civic Auditorium, the installation of art on Portland's transit mall, and the selection of Portlandia for Michael Graves' Portland Building. For example in 1968 when Harry Widman, a Portland artist and teacher (from 1960 till 1995 at of the Northwest College of Art and dean of that school from 1978 to 1981), served on the commission that chose the art work for the auditorium, he observed that politicians and other non-artists on the commission were extremely "gun-shy" about selecting controversial art. Widman recalled that the airport controversy was frequently mentioned by commission members as a precedent to avoid. ${ }^{184}$ The development of "professional" art expert committees that select works was clearly one way to avoid confrontations over artistic definitions. Art for public spaces was no longer selected by one or two cultural elites. However, by creating review panels to select art, the future descions making was opened to greater public review and potential debate.

When the controversy erupted the participants responded with criticisms and defenses that are derived from and dependent on maintaining the "anti-economy" of their interests. The artists and their supporters appeal to the principle of "art for art's sake." For the opponents of art the argument is made by contrasting the art to community values. Bunce and Mrs. Murphy both had a interest in denying the true source of their social position. Bunce had a interest in denying his role in creating class demarcating cultural artifacts. Mrs. Murphy thrived on the attention

${ }^{184}$ Widman, Harry, unpublished interview with Michael P. Craven, (1996), unpaginated. 
accorded her by the press and politicians as leader of the CCOA, and thus she had an interest in maintaining that she was saving art and the community from "Godless" and communistic modernism. When looking at both sides of art controversies it is notable that the more successful and stinging rebukes are those that undermine the "anti-economy" of the other side. Mrs. Murphy's high profile allowed her to be characterized as a media-hungry nut. On the other side Mrs. Murphy characterized the modern art community as self-serving and as cronies of the Museum's clique.

The ultimate outcome of an art controversy is dependent on the ability of the actors involved to maintain the "anti-economy" of their interest. Mrs. Murphy was never able to make a compelling argument that the artists served other interests than "art for art's sake." She could not point to "smut" contained within the paintings and argue that the modern artists served pruient interests, nor could she point to social issues contained within the art to claim that the artists served communist interests. For the artists involved it is fortunate that Mrs. Murphy did not know the depth of their involvement in progressive causes like the American Artists Congress or the Communist Party. Also Mrs. Murphy's deep involvement with the Oregon Society of Artists made her "antieconomy" suspect. By proposing that artists like her husband were being denied recognition, her crusade against modernism was easily dismissed as "sour grapes."

When we scrutinize other controversies surrounding the acceptance of avant-garde art, we realize that three additional factors that contribute to 
the eruption and outcome of art controversies are also present. Consider the controversies of the late 1980s surrounding the National Endowment for the Arts (NEA). Prior to the controversy, the NEA gave grants to many small cutting-edge arts organizations that were alternative artistic outlets to the large elite-dominated art institutions. NEA peer panels sponsored artists and organizations that addressed controversial themes like racism, homophobia, and gender. NEA grants often were an implicit endorsement that allowed the organizations and artists to attract other grants and private funding. In effect, the NEA served as a body that consecrated the art of many controversial artists. The process of peer review had developed as result of controversies like the ones in Portland and was designed to further the freedom of expression of artists ${ }^{185}$ Instead of a handful of political elites picking public sponsored art, artists and other art professionals serving on peer review panels selected the works. In comparison to the abstract art of the 1950s and 1960s, during the 1970s and 1980s art, and especially art sponsored by the NEA increasingly addressed unsettled social issues. These works roused the ire of individuals like Senator Jesse Helms and Reverend Donald Wildmon who objected to the explicit ideological content. Under attack for sponsoring these works, the Bush administration's NEA Director John Frohnmayer eventually created guidelines that severely restricted the sexual and religious contents of NEA supported works. This would point to a failure in the process of elite

${ }^{185}$ Bolton, Richard, "Introduction," Culture Wars, ed. R. Bolton, (New York: The New Press, 1992), p. 9. 
consecration of the arts (the first additional factor) except it could be argued that the NEA sponsored works were never truly consecrated by the elites. To be truly consecrated by the elites, art must serve the cultural capital function of creating class distinction. The controversial NEA works were selected by peer panels and mostly had limited marginalized audiences. ${ }^{186}$ Both political and cultural elites had very little direct involvement with the selection of NEA works. Unlike the Portland cases where the questionable work was essentially reconsecrated by the elites, the NEA works were effectively un-consecrated.

The second additional factor -- a series of controversies, or a prolonged extension of one controversy, that allow participants time to establish positions and strategies -- is clearly present in the NEA controversy. The heated debate over the NEA lasted from 1989 to $1991^{187}$, a sufficient period for the mobilization and strengthening of formal arts advocacy organizations like The National Campaign for Freedom Of Expression to take place. The length of the controversy also allowed critics of avant-garde art to form formal opposition groups, an example being Reverend Donald Wildmon's American Family Association. ${ }^{188}$ The oppososition groups could point to NEA sponsored events such as a traveling exhibition that featured Andres Serrano's Piss Christ and the Robert Mapplethorpe exhibition at the Corcoran Gallery of Art in

186Ibid., p. 22.

${ }^{187}$ Ibid., p. 12.

${ }^{188}$ Ibid. 
Washington, D.C. The shocking nature of these and other works focused national debate on the process by which NEA works are selected and funded. By highlighting these shows the critics of the NEA gave the impression that it was the widespread practice of the NEA to fund obscene art.

The nature of the debate surrounding the NEA also illustrates the additional third factor which ultimately decides the outcome of controversies: The positioning of both the cultural producer and the cultural critic to maintain the "anti-economy" of their positions. To deflate the cultural capital of the supporters of the NEA, the critics of the controversial art maintained that taxpayers were not paying for "arts for arts sake," but were paying to create works that were propaganda for liberal causes like humanism, homosexuality, and feminism. ${ }^{189}$ The supporters of the NEA tried to deflate the political capital of the NEA opponents by insisting that the debate was about the censoring oppressed people's art. Richard Bolton in Culture Wars (1992) noted that the "Few spokespeople came to directly to the defense of the experimental artists and art forms. Commentators instead offered a straight First Amendment defense for the funding of this work, arguing that, while they too were disgusted by the art in question, they supported the right of the artist to be disgusting."190 Bolton also maintains that when proponents of contemporary art argued for the right to freedom of expression instead of the right to sexuality, the

${ }^{189}$ Ibid., p. 18.

190Ibid., p. 19. 
art world acted as if content didn't matter and created the impression that the art world was "insulated and aloof" and "deliberately sidestepping what was on people's minds."191 By not engaging in a debate defining art, the sponsors of contemporary art allowed Senator Jesse Helms and others to define the art in question as pornography and overtly political. The antieconomy of the NEA artists was weakened because their opponents could maintain that the artists served other interests than "art for arts sake."

Even when opponents of avant-garde art are successful in limiting or restricting the public display of controversial art, it must not be forgotten that being a controversial artist imbues an artist with another type of cultural capital: infamy. Controversies also strengthen the cultural distinction between classes as well as the relationship between the cultural producer and the dominant class. Louis Bunce's reputation in the small Portland art world was enhanced after the airport mural controversy. There is not enough evidence to conclude that the controversies created a climate that allowed the birth of Portland galleries like the Fountain and the Image, but it does seem plausible to suggest that the controversies help the create a awareness of modern art that indirectly helped those galleries to succeed. The NEA controversies made Robert Mapplethorpe a household name, and Annie Sprinkle, Tim Miller, and other artists defunded by the NEA are more widely known because of the controversies.

It is the interaction of the controversial art and the currents of ideology that make art controversies more likely in one place and time

${ }^{191}$ Ibid., p. 23. 
than another place and time. The participants in a controversy must be able to convert their cultural capital deficits into political capital. This conversion requires greater ideological currents to be present. At the time of the Portland case, the ideological current that contained antiintellectualism, anti-communism, and anti-elitism was present and contributed to the positioning of opponents of abstract art. A component to Portland's controversies was Oregon's strong tradition of populism. Local traditions and political dynamics contribute to the likelihood of a controversy erupting. The relative independence and maturity of the art world in a city are also factors that contribute to the likelihood of controversies erupting. In the Portland of the 1950s, the modern art world was small, dependent on one or two elite-sponsored institutions, and relatively young. It is hard to imagine the same type of controversy happening in one of the major eastern cities, or even in the Portland ten years later.

Art controversies differ from other public controversies like land use or highway placement because of unique cultural elements that are essential for the production of art. Cultural artifacts create cultural distinctions that serve the class interests, but that interest is shrouded in the language of "art for art's sake." When a neighborhood is condemned for a new highway or urban development, the economic interests are usually evident to all involved. The terms of the debate in this type of controversy are whether the economic interests outweigh quality of life and environmental interests. In art controversies the debate is in terms of whether the work is truly art and/or if that art is linked to a ideological 
issue. The opponents of the controversial art may resent the taxpayer support of objectionable art, but that economic concern is secondary to the ideological issue.

In conclusion, what the Portland controversies most clearly demonstrate is that art controversies are not about the ideological content of art per se, but over the right to define art. Defining what is art is a privilege of the elites that is extended by proxy to the art professionals. The process of creating cultural distinctions, and thus differing definitions of art, inflicts symbolic violence on those who do not possess the cultural capital to interpret the art. It forces the oppressed to ask "Is that art?" When that question is asked, politicians and the media look to the cultural elites for guidance. In the Portland cases, the elites though their proxies respond forcefully, saying that the controversial works were art, so the media and politicians acquiesced to their decision. In the NEA case, because the arts in question did not further cultural distinction, elites and their proxies did not actively enter the debate. This demonstrates what $C$. Wright Mills and other conflict theorists contend; elites only enter the public discourse when their privilege is threatened. When the critical question "Is that art?" arises, the answer from the artistic and cultural elite communities must be in anti-economic terms that further the charismatic myth of art for art's sake or the artists will not win the debate. 


\section{References}

\section{Published Material}

Becker, Howard. Art Worlds, (Berkeley, CA: University of California Press, 1984).

Beisel, Nicola. "Morals Versus Art: Censorship, The Politics Of Interpretation, And The Victorian Nude", American Sociological Review, vol. 58, (1993), pp. 145-162.

Bellaire, Joan. Our Future as Revealed by "Modern" Art, (Fullerton, CA: Educational news Service, 1960).

Bolton, Richard. "Introduction", Culture Wars, ed. R. Bolton, (New York: The New Press, 1992), pp. 3-26.

Bosker, Gideon, and Lencek, Lena. Frozen Music: History of Portland's Architecture, (Portland: Western Imprints, The Press of the Oregon Historical Society, 1985).

Bourdieu, Pierre. Distinction, (Cambridge, MA: Harvard University Press, 1984).

The Field of Cultural Production: Essays on Art and Literature, (New York: Columbia University Press, 1993).

Clapp, Jane. Art Censorship, (Metuchen, N.J.: The Scarecrow Press, 1972). 
Cowels, Charles and Kingsbury, Martha. Northwest Traditions, exh. cat., (Seattle: Seatle Art Museum Press, 1978).

Dubin, Steven. Arresting Images: Impolite Art and Uncivil Actions, (New York: Routledge, 1992).

Fielding, N. G. and Fielding, J. L. "Triangulation," Linking Data, (New York: Sage, 1986).

Graham, Laurel. "Archival Research in Intertextual Analysis," Investigating Subjectively, (New York: Sage, 1992).

Greenberg, Clement. "Towards a Newer Laocoon," Art in Theory 1900 1990, ed. Harrison, C \& Wood, P, (Cambridge, Mass: Blackwell, 1993), pp. 554-560.

Griffin, Rachael. "Portland and its Environs," Art of the Pacific Northwest: From the 1930s to the Present, exh. cat., ed. Adelyn Breeskin, (Washington, DC: Smithsonian Institution Press, 1974), pp. 138.

Guenther, Bruce. 50 Northwest Artists, (San Francisco: Chronicle Books, 1983).

Harris, Jonathan. "Modernism and Culture in the U S A, 1930-1960", Modernism in Dispute: Art since the Forties, ed. P. Wood, et al, (New Haven, CT: Yale University Press, 1993), pp. 2-74.

Hine, Thomas. Populuxe, (New York: Knopf, 1986). 
Hofstader, Richard. Anti-Intellectualism in American Life, (New York:: Knopf, 1962).

Holbrook, Stuart. Mr. Otis, (New York: McMillin, 1958).

Holland, Katherine. Julia Hoffman: A Family Album, exh. cat., (San Fransico: San Fransico Museum of Modern Art Press, 1977).

Horowitz, David A. Beyond Left and Right: Insurgency and the Establishment, (Chicago: University of Illinois Press, 1997).

Jones, Barbara. Jet Dreams: Art of the Fifties in the Northwest, (Seattle: University of Washington Press, 1995).

Kingsbury, Martha. Art of the Thirties, the Pacific Northwest, exh. cat., (Seattle: Henry Art Gallery, University of Washington Press, 1972).

Landgren, Marchal. Years of Art, The Story of the Art Students League of New York, (New York: Art Students League of New York, 1940).

Life. $\quad$ "Is he the greatest living painter in the United States," (Aug. 8, 1949), pp. $42-43$.

"Art of the West," (Nov. 4, 1957), pp. $65-69$.

MacColl, E. Kimbark. The Growth of a City, (Portland: The Georgian Press, 1979). 
Marling, Karal Ann. As Seen on T.V. (Cambridge, Mass: Harvard Press, 1994).

Munk, Michael. "Oregon Tests Academic Freedom in (Cold) Wartime: The Reed College Trustees versus Stanley Moore", Oregon Historical Quarterly, vol. 97, no. 3, (Fall, 1996), pp. 262-354.

Ortega y Gasset, José. The Dehumanization of Art: And Other Essays on Art, Culture, and Literature, (Princeton, N.J.: Princeton University Press, 1968).

Rosenberg, Harold. "The American Action Painters," Art in Theory 1900 1990, ed. Harrison, C. \& Wood, P. (Cambridge, Mass: Blackwell, 1993), pp. 581-584.

Rosenfield, Rachel. Louis Bunce, A Retrospective, exh. cat., (Portland: Portland Art Museum, 1979).

Schnitzer, Arlene. Fountain Gallery of Art, 25th Anniversary Exhibition, exh. cat., (Portland: Fountain Gallery, Portland, 1984).

Time. "Chaos Damm It," (Nov. 20, 1950), pp. 70 - 71.

Wolfe, Tom. The Painted Word, (New York: Bantam Books, 1976).

Wolff, Janet. The Social Production Of Art, (New York: New York University Press, 1993). 


\section{Newspaper References}

The following citations are in format of the Oregonian/Oregon Journal Index.

\section{Oregonian}

14 Dec. 1936 p 3. "Portland artists receives contract (L Bunce)"

4 June $1949 \sec 3$ p 12. "Art directors check entries"

19 June $1949 \sec 1$ p 20. "Art judges select 50 outstanding creations of Oregon artists for 1949"

21 June 1949 p 20. "Funds for Museum has tough going"

26 June 1949 sec 1 p 20 ."Modernism gets accent in Oregon art exhibit"

5 July 1949 p 14. "Ed: The art museum shows"

17 July 1949 city news $p$ 1. "Oregon's conservative artists object to being excluded from museum shows"

7 Sep. 1949 p 17. "Art Museum cuts deplored"

13 Oct. 1949 p 12. "Museum boss urges help"

16 Oct. 1949 City News p 1. "Art Museum meets plaint"

20 Mar. 1955 NW roto $\mathrm{p} \mathrm{6,7}$ "Louis Bunce - a modern artist sees Oregon."

2 Feb. 1957 Sec 2 p 7 c 1 . "Governor Holmes fills five positions on Portland's nine-man port agency"

12 Feb. 1958 p 1 c 2. "Abstract art for airport Declared to need score card"

13 Feb. 1958 p 18 c 2. "Gateway art"

16 Feb. 1958 p 28 c 1. "Space conflict! Port ponders the world of abstract art, Louis Bunce mural for airport"

17 Feb. 1958 p 10 c 7. "Let: Silly Wisecracks"

7 Mar. 1958 p 1 c 2. "Art groups warmly recommend controversial mural" 
10 Mar. $1958 \sec 3$ p 6 c 1 . "Statue Salem spurned now in museum here"

11 Mar. 1958 p 1 c 1. "Bunce gets free hand from Port (additional details on $p$ 12)"

12 Mar. 1958 p 14 c 1. "Ed: Mural Decision sound"

3 May 1958 p 10 c 1. "Ed: Hatchet buried at last (Port of Portland)"

21 June 1958 p 1 c 1 . "Airport mural nears completion (additional pictures on page 5)"

7 Aug. 1958 p 1 c 2. "Louis Bunce Mural has first Viewing at Airport""

10 Aug. 1958 p 38 c 2. "Ed: Bunce's 'Visual world'"

15 Oct. 1958 p 14 c 3. "Letter: Bunce, Louis - Mr. Bunce replies"

14 Dec. 1958 sec 4 p 2 c 1. "Bunce plans 'Donut' art"

19 Dec. $1958 \sec 3$ p 19 c 1 . "Bunce pledges top talent in doughnut shop mural to stir public interest in art"

17 May 1959 p 37 c 1. "Agitation over Bunce mural at airport Dec.lared 'healthy' for stirring interest in art"

8 July 1959 p 16 c 4. "Art dispute flares again (see page 1 also)"

14 July 1959 p 5 c 3. "Latest Bunce painting unveiled"

30 Aug. 1959 p 38 c 1. "Traditional, modern arts schools fires opening shots in battle over state Fair exhibits"

25 Sep. 1959 p 17 c 4. "Wary council okays mosaic 'wall Decoration' for zoo"

8 Nov. 1959 p 41 c 4. "Bunce mural up for sale"

10 Nov. $1959 \sec 2$ p 12 c 3. "Art Museum slate upset"

4 Dec. 1959 p 26 c 7. "Letter: The people own corner; Nobody wants

17 June 1960 p 1 c 1. "'Traditional' art group tees off at money use"

21 June 1960 p 12 c 2. "Ed: Have a look" 
9 Sep. 1960 p 22 c 4 . "The peoples own corner: Disillusioned art director"

10 Feb. 1961 p 21 c 1. "Artist group denies snub, Oregon Independent Artists"

15 Aug. 1961 p 7 c 1. "Bunce works on building art"

24 Aug. 1961 p 8 c 4. "Art society files protest"

14 Sep. 1961 p 14 c 3. "Louie's labors were reflected in this section of mural"

5 Dec. 1961 p 10 c 1. "Portland Art association ballot settles fractional row"

10 Dec. 1961 sec 2 p 8 c 4. "Role of individual vital, museum director says"

14 Dec. $1961 \sec 2$ p 2 c 6 . "Bunce mural presented"

24 Dec. 1961 sec 2 p 8 c 4 . "Annual art report impressive"

27 Mar. 1962 p 17 c 3. " Maintenance worker creates stir with modern painting at city hall"

5 Aug. $1962 \sec 2$ p 14 c 1. "Bunce paints on wall, voila! its a big mural."

15 Dec. 1963 sec 2 p 16 c 1. "Comments on Artists of Oregon exhibition at Museum"

5 Jan. $1964 \sec 2$ p 10 c 1 . :Policy review of Oregon show part of experimental history Opinions given on Museum's 'Artist of Oregon Exhibition'"

14 June $1964 \sec 2$ p 15 c 2. "Changes slated in Oregon annual Artists of Oregon's Large number of listings under art exhibitions re: This show"

9 Nov. $1964 \sec 2$ p 3 c 6 . "Group re-elects Mrs. Murphy"

24 Nov. 1964 p 5 c 4. "Tax subsidies for arts hit."

7 Jan. 1965 sec 2 p 14 c. "Portland artist group sites culture void in Rose Festival; suggestions said ignored"

6 Mar. $1966 \sec 2$ p 21 c 3 "Jury choice stirs revolt" 
20 Mar. $1966 \sec 2$ p 16 c .1. "First-rate works, mediocrity, 'clinkers' seen in annual"

17 Jan. 1968 p 16 c 1 . "Bunce selected to paint mural for Concord Building"

22 Aug. 1967 p 22 c 1. "Ed: 75 years of art"

10 Dec. 1967 sec 2 p $28 \mathrm{c}$. "Art Museum's ups and downs recalled for diamond jubilee"

15 July 1969 p 9 c 2. "Firms turn to art in growing numbers"

5 Oct. $1969 \sec 2$ p 16 с 2 "Tax battle carried to senate committee Portland Art Museum director receives Belmaont Report"

21 Dec. 1969 p 37 c 1. "City seeks art controls"

19 Jan. 1975 NW Magazine p. 4. "Louis Bunce - an Introspective Journey"

16 Nov. 1979 p E4 c 1. "Art Show Features Oregon 'superstar' (Louis Bunce)"

16 Nov. 1982 p E4 c 1. "Happy Birthday, Louis Bunce"

12 June 1983 p D9. "Artist Louis Bunce dies at 75"

17 June 1983 p E8. "300 recall artist Bunce"

\section{Oregon Journal}

19 June 1949 p 2. "Art Museum's policy of selecting exhibits explained by Director"

26 June 1949 p 8. "New Museum policy stirs"

4 Sep. 1949 Mag. sec p 3. "Art for heaven's sake"

11 Oct. 1949 sec 2 p 8. "Museum defends selection"

24 July 1949 p 12a. "First NW. 'Village Art Fair" draws thousands"

30 Nov. 1949 p 22. "Ed: Artist's Quarrel"

25 Jan. 1950 p 14. "Ed: Local Art" 
25 June 1952 p 5 . "Art museum asks county to give funds of $\$ 10,000 "$

16 Sep. $1952 \sec 2$ p 1 . "Modern art stirred city 50 years ago"

2 Aug. 1956 p 6 c 4. "Plans to support art stirs vocal objections"

27 Feb. 1957 sec 2 p 4 c 1 . "Bunce takes trip north"

14 Apr. 1957 p 10 A c 2. "Art alliance "flies from museum nest"'

11 Feb. 1958 p 1 c 7. "Airport mural too modernistic"

13 Feb. 1958 p 9 c 1 "Port group may reconsider painting rejection, Art group offers services, Louis Bunce artist"

14 Feb. 1958 sec 4 p 4 c 1. "Ed: Let artist, Port men compromise"

20 Feb. 1958 p 11 c 7. "Port asks help of art arbiters"

7 Mar. 1958 p 3 c 2. "Art advisers OK disputed Bunce mural"

11 Mar. 1958 p 2 c 6 . "Port Oks Bunce art for airport (also see story p 6)"

12 Mar. 1958 p 3 c 3. "Art advisors OK disputed Bunce Mural"

12 Mar. 1958 p 11 c 1. "Airport muralist's studio burns late at night"

18 Mar. 1958 p 4 c 7. "Ed: Experts on art should have say on Dec.orations"

2 May 1958 p 2 c 7. "Peace near in Portland airport row"

3 May 1958 p 8 c 1. "Ed: Conciliation of airport issues"

8 Feb. 1959 Cent sect R p 16 c 3. "Portland early became Oregon art hub"

28 Apr. 1959 p 1 c 14. "Mural for centennial sure to create splash"

5 June 1959 p 2b c 3. "Ed: Murals Debated"

20 Aug. 1959 p 7 c 6 . "Citizens for Art' chosen as new organization's name"

26 Aug. 1959 p 20 c 4. Letter: "Mission completed, by Mrs. C. G. Murphy 'beautiful' art aim of group"

7 June 1959 p 8B c 1. "Art for Artists select slogan"

1 Nov. 1959 p 24a c 5. "Art gains in state" 
13 Aug. 1961 p 3 c 6 . "Controversial artist hired for vast mural "

5 Dec. 1961 p 4 c 2. "Portland Art Association elects 5 board members; 2 renamed"

31 Jan. 1962 p 2 c 1 . "County's $\$ 10,000$ ordered for art."

13 Nov. 1962 p 2 c 5. "Accord marks annual meet of Portland Art Museum"

13 Mar. $1963 \sec 2$ p 2 c 4. "Bunce serigraph selected for Hilton"

19 Apr. 1963 sec 2 p 4 c 1 . "How far out is modern art"

25 June 1963 p 1 c 5 . "Lovers of traditional art fight tax bite for Museum"

26 June 1963 p 2 c 7. Baker, Doug: "Baker's Dozen"

27 June 1963 p 4 c 3. "Works of abstractionists 'heady'"

27 June 1963 p 2 c 1. " $\$ 10,000$ budget for Museum sparks controversy"

28 June $1963 \sec 2$ p 2 c 4. "Festival art review draws comment"

13 Dec. 1963 sec 2 p 2 c 5. "What's hung, hangs itself"

12 Dec. 1964 p 2 c 8. "Officers named by art group, Mrs. C. G. Murphy"

28 Apr. 1967 sec 2 p 16 c 1 . "Art Museum's shocker has wings, doesn't fly"

27 May 1967 p D2 Baker, Doug: "Bakers Dozen: Nickel-Nursing Portland Deserves Third Rate Art?"

1 June 1968 p D2 Baker, Doug: "Bakers Dozen", (June 1, 1968), p. D2.

8 July 1968 p 10 c 6. "Art show gets out of hand, may be last, sponsor says"

7 Sep. 1977 Baker, Doug: "Baker's Dozen: Oregon's Gully Jimson." 


\section{Unpublished Material}

Bunce, Eda. Unpublished interview with Michael P. Craven, (1996).

Bunce, Jon. Unpublished interview with Michael P. Craven, (1996).

Bunce, Louis. Oregon Historical Society Interview, (circa 1979).

Gilkey, Gordon. Unpublished interview with Michael P. Craven, (1996).

Gilkey, Gordon. Letters to Mrs. Chester G. Murphy, (May 16 - June 27, 1960). Courtesy of Gordon Gilkey.

Lindsay, Dennis. Unpublished interview with Michael P. Craven, (1996).

McLarty, Jack \& Barbara. Unpublished interview with Michael P. Craven, (1996).

Murphy, Mrs. Chester G. Summary of Activities, Citizens for Art, 1959, (Author presumed to be Mrs. C. G. Murphy: circa 1960).

Murphy, Mrs. Chester G. Personal scrapbook of unidentified newspaper clippings and correspondence: 1959 - 1970.

Murphy, Mrs. Chester G. Letters to Gordon Gilkey, (May 12 - June 21, 1960). Courtesy of Gordon Gilkey.

Oregon Historical Society's Vertical Files: Hoffman Family, Louis Bunce, Portland Airport, \& Portland Art. 
Port of Portland Board of Commissioners Minutes, (August 12, 1957 March 10, 1958), pp. 62 - 145.

Portland Art Association. Unpublished report: "Some Landmarks", (1960).

Portland Art Museum Library's Northwest Artist Files: Louis Bunce.

Shotola, Robert. Unpublished paper: "Artistic Activity in Portland, 1890 1950", (1981).

van Gent, Ans. Unpublished paper: "Oregon Society of Artists", (1980).

Widman, Harry. Unpublished interview with Michael P. Craven, (1996). 


\section{Appendix: Notes on Methodology}

I analyzed this particular case using inductive methods of research with the goal of constructing theory. I did not gather specific data to test a specific hypothesis, but I realized my choice of previous theory did impact the types of information I gathered. The primary concern of my analysis was to uncover the social relationships with which the meaning of art was imbedded in this particular case. I did not want to begin my research with preconceived categories of data that I must collect. The related theory and research suggest possible areas to investigate, but as I am taking a holistic approach toward the question, I do not intend my analysis to be limited by previous scholars' work. My goal was to reconstruct a thick description of this case, allowing for the understanding of this particular phenomenon in its historical context.

The most critical component of this analysis was the historical reconstruction of the specific case. A wide variety of information exists with which to analyze this case and a variety of tools were required to collect it. I gathered information from several different sources. A) newspaper articles from the period, B) archives of Portland Art Museum and Oregon Historical Society, C) personal letters and scrapbooks of individuals involved in the controversy, and D) interviews with individuals associated with the controversy. Similar to Laurel Graham in "Archival Research in Intertextual Analysis" (1992), I moved from the most public sources to the more private sources.

I had no problems with access to the newspaper articles or the archive of the Oregon Historical Society or the Portland Art Museum. I obtained access to the scrapbook of Mrs. Murphy because she had given a copy of that collection to a undergraduate student who had interviewed her for a term project. I was fortunate that collection is now in P.S.U.'s possession because Mrs. Murphy is now deceased. Dr. Gordon Gilkey graciously gave me copies of his correspondence with Mrs. Murphy.

Another source of information I used was people who participated in or witnessed this controversy. I compiled a list of living participants in the controversy that $I$ could interview. Unfortunately many of the key 
figures are dead, as this controversy occurred more than forty years ago. I did not restrict my interviewing to only key participants in the controversy; for example I interviewed Jon Bunce and Jack McLarty. After my initial archival research I constructed a interview guide and check list. I found that early interviews suggested additional questions for later interviews and archival research. All but one of the interviews were tape recorded and subsequently transcribed. It is my hope to place these transcripts with the Oregon Historical Society as they may be of value for other researchers. Unfortunately, the interview with Dennis Lindsay was by phone and not recorded.

Using "between methods" triangulation ${ }^{192}$ I compared archival and interview information for accuracy. I also looked at changes that occurred over time. I analyzed the art community before, during and after this controversy thus using "time triangulation."193

192Fielding, N. G. and Fielding, J. L., "Triangulation", Linking Data, (New York: Sage, 1986), p. 25.

${ }^{193}$ Ibid. 